Universidade de Brasília

Departamento de Teoria Literária e Literaturas

Programa de Pós-Graduação em Literatura

Lucas Sales Lyra

Poesia e pensamento:

ensaio para o corpo e a comunidade 
Universidade de Brasília

Departamento de Teoria Literária e Literaturas

Programa de Pós-Graduação em Literatura

\author{
Lucas Sales Lyra
}

\title{
Poesia e pensamento: ensaio para o corpo e a comunidade
}

Dissertação apresentada ao Programa de PósGraduação em Literatura do Departamento de Teoria Literária e Literaturas da Universidade de Brasília, como parte dos requisitos para obtenção do grau de Mestre em Literatura, elaborada sob orientação do Professor Dr. Piero Luis Zanetti Eyben.

Brasília - DF 


\title{
LUCAS SALES LYRA
}

\section{POESIA E PENSAMENTO: ENSAIO PARA O CORPO E A COMUNIDADE}

\begin{abstract}
Dissertação apresentada ao Programa de Pós-Graduação em Literatura do Departamento de Teoria Literária e Literaturas da Universidade de Brasília, aprovada pela banca examinadora.
\end{abstract}

Brasília, 13 de fevereiro de 2015.

Dr. Piero Luis Zanetti Eyben

Universidade de Brasília — Presidente

Dra. Bernardina Maria de Sousa Leal

Universidade Federal Fluminense - Membro Externo

Dra. Fabricia Walace Rodrigues

Universidade de Brasília — Membro Interno

Dra. Elizabeth de Andrade Lima Hazin

Universidade de Brasília - Membro Interno - Suplente 



\section{Dedicatória}

A quem leia, a quem interessar, e a quem se interessou por ler. 
Agradeço às professoras - profa. Dra. Fabricia Walace Rodrigues, profa. Dra. Bernardina Maria de Sousa Leal e ao membro suplente profa. Dra. Elizabeth de Andrade Lima Hazin - pelo aceite do convite de formação da banca.

Agradeço ao meu orientador e membro da banca prof. Dr. Piero Luis Zanetti Eyben pelas leituras cuidadosas, comentários e orientação que não só me auxiliaram nesse processo de escrita, mas participaram da minha formação intelectual e aprendizagem, processo mais amplo e contínuo cuja importância este texto deixa apenas entrever.

Agradeço à minha família pelo apoio e suporte e ao Pedro pelas conversas, amizade e o incentivo, participação que me ajudou em muito.

E aos colegas de estudo do Grupo de Pesquisa Escritura: Linguagem e Pensamento pelo trabalho em equipe para um pensamento em comum e interesse nessa etapa de minha formação também sou grato.

Dos amigos, agradeço à Isadora por me ajudar conversando e à Luísa Freitas pela companhia, conselhos e sua amizade.

Agradeço ao Programa de Pós-Graduação em Literatura e à Universidade de Brasília pelo apoio institucional. Agradeço, enfim, também à CAPES pelo auxílio financeiro nesse processo. 


\section{Resumo}

LYRA, Lucas Sales. Poesia e pensamento: ensaio para o corpo e a comunidade.

Dissertação de Mestrado. Orientador Piero Luis Zanetti Eyben. Brasília: Universidade de Brasília, 2015, 121 p.

A poesia de Safo de Lesbos é milenar e no entanto ainda está às margens do cânone literário. Contudo, esperamos demonstrar que isso não é de todo negativo. Sua não pertença ao cânone, seu como que apagamento da literatura, acabou por consagrá-la a um nicho de pesquisa, em sua especificidade, dos estudos helênicos. Ainda que configure um objeto de pesquisa, seu interesse de estudos acabou sendo historicamente estabelecido enquanto fonte de perguntas em nível antropológico, biográfico e social. Contudo seja esse agora seu lugar acadêmico, gostaríamos de discutir a noção de que sua não pertença ao cânone revela aspectos de soberania e absolutismo dos conceitos fundamentais em que se sustenta a moderna crítica literária. A isso nos dedicamos em nossa pesquisa monográfica de conclusão de curso. Com o presente trabalho, contudo, quer-se demonstrar que a poesia de Safo é capaz de sustentar um pensamento escritural (não teorético) de grande porte. Para tanto, apresentamos aqui o debate teórico do pensamento francês contemporâneo sobre as ideias de corpo e comunidade e avançamos a proposta de que a lírica de Safo é um belíssimo exemplo avant la lettre da segunda, ao passo que está bem à frente dos debates teóricos contemporâneos quanto à primeira, pois permite uma concepção de corpo que gera um entendimento de textualidade próprio, segundo as ideias de fragmentação e incompletude, e menos absolutista porque menos arraigado às ideias de subjetividade, consciência e intencionalidade que sustentam o logocentrismo do pensamento especulativo literário. Para encaminhar esse argumento, seguimos a linha teórica da desconstrução de Jacques Derrida em um debate entre Jean-Luc Nancy e Maurice Blanchot, às voltas com Georges Bataille.

Palavras-chave: Safo de Lesbos; Lírica arcaica; Jacques Derrida; corpo; comunidade. 


\begin{abstract}
LYRA, Lucas Sales. Poetry and thought: an essay towards body and community. Master's dissertation. Supervised by Piero Luis Zanetti Eyben. Brasília: University of Brasília, 2015, 121 p.
\end{abstract}

Sappho's lyrical poetry is by now of millenary power, but she remains outside the literary canon however steady her poetry still stands. Her marginalization from the canon and erasure from literature has resulted in a granted niche of research, however very specific, in modern Greek Studies. Even though to some she configures as a fine subject of enquiry, the interest she provides to speculative thinking has been so far historically established as pertaining almost exclusively to anthropological, biographical, cultural and social questions and they, if not motivated by linguistic interest, almost never concern her poetry. They certainly do not concern her poetry as an aesthetic and scriptural field of enquiry to problems of contemporary thought. For those reasons, we would like to discuss the notion that her absence from the canon actually reveals modern literary critic's sovereign statute and absolutist character. In order to discuss Sappho's importance to contemporary thought, we present the contemporary French debate about the ideas of body and community and advance the proposal that her lyric is a beautiful example of community but is however far ahead as to what concerns the body. Her poetry allows for a less absolutist understanding of text for its fragmentary character because it is entirely absent from the ideas of subjectivity, consciousness and intentionality that have given modern literary critic the strength to keep its logocentric hold on text and culture. To give course to that purpose, we follow Jacque Derrida's theory of Deconstruction and fuel a debate between Jean-Luc Nancy and Maurice Blanchot in their desire to understand Georges Bataille's literary and theoretical texts.

Keywords: Sappho; Ancient lyric; Jacques Derrida; body; community. 


\section{Sumário}

INTRODUÇÃO

\section{CAPITULO 1 - Comunidades}

1.1. O problema da comunidade em questão

1.2. A comunidade de Blanchot

1.3. O princípio de insuficiência

1.4. A comunidade não é uma soma de unidades

1.5. Comunidade e individuação: imanências

1.6. Figuras de coletividade: "espírito", desde os átomos

1.7. O amor e o desejo, Aufhebung

1.8. Comunidade e inscrição, para escrituras

1.9. Morte e figuras de alteridade

1.10. Comunidade, passagem, partilha

1.11. O objeto do êxtase

1.12. Comunidades literárias: exposição e partilha 
2.1. A comunidade do mais de um

2.2. Figuras literárias da comunidade - Tristão e Isolda

e La maladie de la mort

2.3. Entre abismo, mesmo e outro: erotismo de Bataille

2.3.1. Descontinuidade e reprodução

2.3.2. Parte feminina, receptáculo de sentido

2.3.3. Erotismo como redução do outro ao Mesmo

2.4. As comunidades de Nancy: sessão de abertura

2.4.1. Comunidade dos espaços: axiologia

2.4.2. Comunismo: ideário fracassado de partilha

CAPÍtUlo 3 - Releituras, Literatura avant la lettre 75

3.1 Heranças e releituras da comunidade

3.2 Releituras do "ser-com" heideggeriano

3.3 Corpus literário

3.3.1 O erotismo é forma de entendimento-a-si

3.3.2 Diacronia do corpo: signo corpóreo

3.3.3 Outras saídas teóricas: corpo como figura extensa

3.4 O corpo histórico é um sujeito deslocado

3.4.1 Corpo como presença reapropriada

3.4.2 Aufhebung - sujeito enlevado a corpo

3.5 A poesia de Safo de Lesbos

3.5.1 Contra exemplo da historicidade do corpo

3.5.2 Cotejo à hermenêutica do êxtase segundo Leo Spitzer

3.6 Comunidades líricas

3.6.1 Respostas de Safo à comunidade e corpo 
3.6.2 Membros da comunidade sáfica

3.6.3 A morte e o que se deixa

CONSIDERAÇÕES FINAIS

1 O erotismo de Safo não é um erotismo

2 Safo entre corpo e fragmento

3 O êxtase em Safo não pode ser um êxtase

4 Retomada - êxtase, erotismo e corpo histórico

5 Fragmenta

BIBLIOGRAFIA 
INTRODUÇÃO 
Os estudos contemporâneos sobre a questão do corpo estão intimamente ligados ao debate sobre a questão da comunidade que entreteve Jean-Luc Nancy e Maurice Blanchot em um importante diálogo cuja última palavra coube a Nancy há pouco tempo em $2014^{1}$.

Os recentes estudos sobre a questão do corpo têm já, apesar do pouco tempo, fortuna crítica. Há como que um comum entendimento sobre o que a palavra corpo significa. Por vezes, em textos, ela é um conceito; por outras, refere-se à coisa que uma qualquer outra palavra indicaria, o objeto a que se apontaria, caso frente a ele. Contudo esteja claro que "corpo" deve ainda levar a novas perguntas, para que haja, e que tenha havido, uma certa comunidade às voltas com essa palavra, debruçada sobre esse tema, é preciso que algo a respeito de "corpo" tenha sido estabelecido para que o diálogo se dê.

Essas, conceito e referência, não são as duas únicas possibilidades. Sabe-se também que não é questão de eleger um significado preferido entre alguns vários. Há uma verdadeira necessidade de comum acordo; senão, qualquer possibilidade de entendimento e diálogo (caso em que recai o que se chama aqui de uma fortuna crítica) estaria completamente fora de questão.

Por isso, para uns tantos que se usaram dessa palavra de maneira temática, técnica, estética ou especulativa, isto é, quiseram de seu uso alguma importância, "corpo" significou algo cujo sentido precisou ser compartilhado entre o grupo que se cerca em volta desse tema. Logo, para uma comunidade acadêmica da qual se requisita uma produção autorreferencial, que se reporta a outras produções acadêmicas, a noção de diálogo deve ser importantíssima. $\mathrm{E}$, logo, um entendimento convencional e de comum acordo da palavra que designa certa comunidade deve ser desejado.

Não que "corpo" seja ponto pacífico para o conjunto de textos a que nos referimos, pois certo que esse "conjunto de textos" pode, sendo maleável, ser estendido a este ou aquele limite ou alcance e, caso fosse ponto pacífico, tal

\footnotetext{
${ }^{1}$ A questão foi proposta com Jean-Luc Nancy com La communauté desoeuvrée. Blanchot responde com La communauté inavouable. Recentemente em 2014 Nancy retomou com La communauté desavouée.
} 
questão por certo não designaria nenhuma comunidade, bem que pudesse dela tomar parte.

A comunidade sobre o corpo a que nos referimos começa, bem ou mal, com os franceses, mesmo que se possa dizer ter começado antes, bem antes ou jamais ter sido efetivada, ou não ainda; contudo apenas depois dos contemporânos se possa dizer "antes", "bem antes" ou "não ainda". É certo que se procurarmos para quem o corpo foi uma questão acharemos muitos exemplos antes dos franceses, e alguns outros franceses antes deles, mas não nos interessa quem falou sobre corpos sozinho.

Claro que poderíamos estabelecer uma comunidade que se estendesse, depois de seu nascimento, àqueles que dela participaram antes da hora, ou um pouco depois. Mas aí toda a efetividade de uma comunidade começaria a ruir diante os nossos olhos, ao ponto de que talvez já fosse, antes de ter nascido, uma impossibilidade de definição de seu limites; ou mesmo que qualquer comunidade já nascesse às escuras. Esse é justamente o caso da comunidade sobre o "corpo". E o da comunidade sobre a "comunidade".

O que une as duas, além de estarem ambas entre o serem inatuais e serem atuais em uma inatualidade própria, é que ambas resistem à qualquer definição de seus limites, apesar de terem de acordar sobre o que dizem quando falam em "corpo", "comunidade" e, portanto, terem de delimitar suas falas sobre os corpos, sobre as comunidades.

Uma fortuna sobre o corpo é ainda premente. História do corpo de JeanJacques Courtine e Georges Vigarello, uma grande referência sobre o tema, foi recentemente reeditado. Uma fortuna sobre a comunidade, então, deve esperar um pouco mais esse título, pois que a recente contribuição de Nancy pode bem mesmo ser lida como retratação, ou post scriptum, já que é dele também a "primeira palavra". É discutível que um problema da comunidade tenha sequer começado a ser entretido, dado que está ainda "incompleta" sua formulação. Portanto, dada a juventude do problema do "corpo" e da "comunidade", é lícito por agora ressaltar sua pertença contextual ao debate que se deu sobre o fim e o começo da modernidade, especificamente na França, para este trabalho. 
Organizadores de História do corpo, Jean-Jacques Courtine e Georges Vigarello coletaram em três volumes textos autorais sobre essa questão e suas diversas interfaces. De ponto de vista claramente histórico, os textos ali reunidos, mais que fazer uma história do corpo, revelam uma comunidade de pensadores sobre essa questão, o que Ihe ressalta a importância e deixa claro que há ali um debate de entendimentos compartilhados.

É exatamente por isso que a diferença entre conceito e sentido referencial é tanto importantíssima e quase indiferente no caso de "corpo" à comunidade que ali se debruça sobre ela. Organizadores do livro, Courtine e Vigarello não intentaram reunir diferentes perspectivas para uma história de um conceito. O que ali tem preferência é um sentido referencial da palavra, desde o título e em cada texto. Claro que esse sentido referencial para o tema ali abordado é somente prevalente, pois, como ali se deixa ver uma comunidade sobre o tema, o sentido conceitual também está presente. No entanto, ele não é compartilhado entre as diferentes perspectivas como a imagem do objeto mundano "corpo" evocada pela palavra escrita².

O sentido conceitual é múltiplo em História do corpo. Mesmo Courtine, em seu prefácio para a obra ressalta a interdisciplinaridade que requer a história do corpo. Ali entram política, estética, antropologia, filosofia, psicanálise e semiótica (principalmente estas últimas duas) para falar do mesmo assunto. O objeto é um só, as perspectivas são múltiplas. Às perspectivas, estão associadas as diferentes modalidades conceituais de cada "disciplina". Ao objeto, está associada uma palavra que o designa em sua "coisidade", talvez apressadamente - pode-se falar aqui em significante e significado, base binária do processo de significação por referenciação de interno a externo, como podese presumir que "significado" assuma conotações de "objeto", "coisa mundana", "significante derivado" etc.

É por isso que a diferença entre conceito e sentido referencial é importante de ser ressaltada. Especificamente, no entanto, é também por isso

\footnotetext{
${ }^{2}$ Mesmo que se possa intentar generalizar para toda História a ambiguidade entre objeto da historiografia e objeto mundano que "corpo" assume, acreditamos que o caso é específico à questão. De fato, não se vê uma tal correspondência entre essa e outras histórias dado que pode-se fazer história de qualquer coisa, desde um "objeto" até um fenômeno, um movimento social, político, estético etc.
} 
que ela não se sustenta em História do corpo: apesar das diferenças de interface teórica, no que se refere ao que há de comum aos textos ali reunidos, o sentido conceitual não concerne à obra em geral, o que significa dizer que o objeto da história que se faz é o objeto-mundano-corpo.

O caso de História do corpo é o mesmo de O corpo impossível, obra de Eliane Robert Moraes sobre Lautréamont, Bataille e o modernismo francês na especificidade do Surrealismo segundo André Breton. Ali também "corpo" não é um conceito, isto é: não é uma busca do que há de propriedade ao "corpo", não é uma exploração do corpo, nem aproximação de seu horizonte de sentido, nem de sua acontecimentabilidade. O que não é dizer somente que tanto em um e outro não se faz desconstrução, ademais, é dizer que ali se deixam confundir por uma cegueira de princípios, ou "defeito de linguagem".

Para se fazer uma história do conceito de corpo, em verdade, prefere-se narrar uma história de suas predicações (pois sabe-se que "corpo" de todo resiste a uma história enquanto episteme) é preciso passar primeiramente por Descartes (suas suposições lógicas, também lidas husserlianamente como epokhés supressivas de mundo e dúvida e instauradoras de "razão", levam consigo os corpos). Portanto, a primeiridade do corpo é a dúvida, pois começa em uma relação de equivalência ao mundo. Claro que se pode alargar e premeditar Descartes para entender seu contexto. Mas não é absurdo que a noção moderna de corpo nasça com a de sujeito ${ }^{3}$. A figura de animais-máquina em Descartes deixam ver o corpo enquanto autômato ou mecanismo sistemático dotado de organicidade mas não sopro da razão. Também colocam

\footnotetext{
${ }^{3}$ Marcel Mauss lembra que é no Império Romano que se possibilita uma "pessoa", dado que a persona é interpretada como máscara social, política e "pública". Esse conceito será para Mauss a alternativa de um sujeito. Muito semelhante a Michel Foucault, que em Hermenêutica do sujeito e História da sexualidade preocupa-se com a arqueologia do sujeito da consciência desde a Grécia Antiga pelos fenômenos do "cuidado de si" que deixam entrever uma preocupação (cura) com uma autoassepsia moral e frente ao outro. É interessante ressaltar que Foucault apenas se deixa ver um começo de "sujeito" na Grécia da era Clássica, o que indicaria uma proximidade dessa questão às então recentes ruínas de estruturas de poder religioso politeístas para um advento primitivo do pré-cristianismo. Ademais, a proposição de máximas filosóficas tais como a inscrição em Delos "conhece-te a ti mesmo" (Foucault também analisa o daimon conselheiro de Sócrates) como os fenômenos funcionais de uma arqueologia do sujeito inscrevem essa questão no mesmo lugar de um Descartes, pois sabe-se a relativa facilidade de compreensão de "nascimento" (arkhé como "nascer", "originar", "poderio") do sujeito em circunstâncias gnosiológicas.
} 
na mesma margem os problemas de corpo e animal, desde sempre dentro e fora da lógica da ipseidade.

Para Edmund Husserl, o corpo é natureza assim como o outro é o espelhamento da primeiridade do "meu" corpo, o corpo ipse, que no entanto faz parte do mundo de que se deve desconfiar e ser posto em parênteses. Meditações cartesianas e conferências de Paris é a resposta de Husserl às acusações de demasiado solipsismo da fenomenologia que propunha, sua tentativa de aproximação à ciência pura e geral vigilante de todas as ciências. O fato é que Husserl desconfia do corpo tanto quanto Descartes. Propõe que o outro é natureza e não distingue corpo de outro.

A questão do corpo para a fenomenologia é intrínseca ao próprio projeto fenomenológico. Merleau-Ponty demonstra isso na medida em que aprimora o sentido de "sense certainty" ao estudar a percepção espacial corpórea como distinta da percepção lógico-espacial cognitiva. Nisso ele permite que "corpo" não seja para a fenomenologia entendido somente enquanto "objeto" ao mesmo tempo em que revela que esse entendimento coextensivo de corpo e objeto esteve até então prevalente.

Os estudos sobre o corpo também têm grande contribuição de Deleuze \& Guatarri. Em "Como criar para si um corpo sem órgãos", que deve ser entendido junto a "Sobre alguns regimes de signos", a noção de corpo fora de uma organicidade permite compreensões mais profundas do processo de desterritorialização (que é primeiramente a infinitização de remetimento sígnico que transforma "significados" em outros significantes em devir e possibilita comparar a eficácia de sistemas sígnico-representacionais e político-religiosos, o "império dos signos") perpetrada pelo capitalismo como modo de produção e cuja resposta é a esquizofrenia, não como loucura ou diagnóstico biossocial, sintoma do sistema, mas como analogia processual de um quadro sígnico que deixa ver o próprio pela falha.

A noção de plano de imanência de conceitos opõe-se ao plano de composição da imagem de perceptos e afectos. Uma cabe ao pensamento especulativo e a outra à estética vista do modo de sua composição. Deleuze compreende as diferentes áreas ou disciplinas técnicas num plano em que as imagens se reportam umas às outras de modo "sincrônico". Sua noção de pintura, escritura, escultura, cinema é indissociável do conceito de imagem, 
que assume em si uma certa plasticidade e concretude, e o aproxima, em um mesmo plano de imanência conceitual, ao "corpo" entendido enquanto figura.

A noção de corpo é bastante discutida em Heidegger. Se primeiramente, na primeira seção Dasein e espacialidade de seu projeto de investigação Ser e Tempo, o corpo parece ser caro ao empreendimento de sua análise (por exemplo, Heidegger considera a rua "o mais real dos objetos", pois é nela que "tocam nossos pés" quando caminhamos), logo vê-se em Dasein e temporalidade que o corpo toma segundo lugar atrás de questões mais importantes.

Em uma primeira impressão, sabe-se que algumas expressões usadas em Ser e Tempo, como "Vorhandenen" e "Zuhandenen", a partir de suas traduções para a língua portuguesa (em edição de Castilho) e a língua inglesa (em edição de McQuarrie \& Robinson), assinalam a mão (metonimicamente, aqui, entendida como um deslocamento do corpo). Em português traduzidas a primeira como "subsistente" e/ou "disponível" e a segunda como "utilizável", tais conceitos são importantíssimos para a filosofia heideggeriana exposta em seu livro por indicarem a relação de remissão do instrumento com a obra (ou totalidade-de-remissão) a partir da dicotomia expressa onticamente entre o utilizável e o não utilizável (e, portanto, meramente subistente).

No jogo de linguagem dessas palavras, percebe-se como que intuitivamente a proximidade do ser do Dasein com o corpo, sendo esse posteriorimente taxado como não determinante do ser do Dasein. O que resta são índices de que a relação do ser-no-mundo com o ente do interior-domundo advém através da utilizabilidade dos instrumentos sob o modo da ocupação a partir de sua adequação ao corpo. A figura da mão está tanto no utilizável ou disponível (zur Hand - para a mão ou à mão) quanto no simplesmente subsistente, cuja característica pré-ontológica é enfatizada pela preposição alemã vor (vor Hand - antes da mão).

Mais à frente da obra heideggeriana, nos é introduzido o estatuto de primeiridade existenciária da preocupação como o modo mais fundamentalmente originário de entendimento-de-ser a si. A preocupação (Sorge) fundamenta o entendimento-a-si do Dasein enquanto adiantamento em 
relação a si do Dasein. Ela está morfologicamente próxima da ocupação (Besorge), que, por sua vez, designa um estado primeiro de relação do Dasein com o seu ambiente ou mundo-em-volta (Umwelt). A ocupação é a relação do ser com o mundo-em-volta e se dá corporalmente, sendo os utilizáveis os "despertadores" do Dasein à relação de utilizabilidade que pode manter com eles e com sua finalidade de uso.

Já a preocupação como dito é introduzida como mais originária que a ocupação. No entanto, ela aparece na obra heideggeriana no que aparenta ser um estado posterior do entendimento-a-si do Dasein (se pensado em termos fisiológicos ou materiais de uma facticidade do acordar ao entendimento-a-si). Ela adianta o ser em relação-a-si e o lança no que é um tipo de ocupação projetiva, e também constitui o entendimento-a-si do Dasein numa relação-com que é com o mundo, o outro etc.

Até o aparecimento da preocupação como modo de ser mais originário, pela ocupação, outro modo de ser do ser-com, o corpo tinha um lugar de destaque, metonimicamente concretizado pela mão. Encaminhando o Dasein à abertura ao mundo como adiantado em-relação-a-si e em vista de suas possibilidades de ser, já as sendo, o modo-de-ser da ocupação com o mundo, em relação à abertura possibilitada pela preocupação, é visto como queda e decair do Dasein, que, ocupado com as "coisas", é por elas absorvido e com elas está em familiaridade.

Dessa forma, o campo conceitual ligado ao corpo é como que marcado negativamente e relegado a certo esquecimento ao mesmo tempo em que parece resisti-lo. Com o texto De l'esprit: Heidegger et la question de Derrida como guia, aproxima-se do texto heideggeriano em outra ótica: como incorrente num salto sobre o corpo e, portanto, implicado numa metafísica. Para uma percepção da corporeidade enquanto co-constitutiva do apagamento da escritura da História como apresentada por Derrida em De la grammatologie.

Jean-Luc Nancy em seu trabalho Corpus, como mostra Jacques Derrida em Le toucher - Jean-Luc Nancy, entende "corpo" como figura de extensão e medida. Analisando a frase "Psyche ist Ausgedehnt, weiß nichts davon", de Freud, sugere, encenando e espacializando os conceitos, que "Alma", "mente" e "corpo" participam da mesma figura extensiva e portanto inscrevem-se na 
lógica metafísica da presença, uma "conclusão" demasiado e apressadamente derridiana.

Psyche é extensa, nada sabe disso. Nancy leva essa citação freudiana ao seu mais radical, propondo uma nova concepção de "toque", intimamente conectada a sua original concepção de limite. O limite, conclui, é tocar o intocável e tocar é sempre tocar os limites. Essa premissa estrutura-se semelhantemente às máximas derridianas, que subsituem "estrutura" por "força", em que as condições de possibilidade são inscritas e pressupostas pela possibilidade de impossibilidade que também devem um tanto a uma interpretação não hegeliana da denegação do inconsciente de Freud.

Contudo seja preciso passar por esse caminho, aqui nos reservamos a apenas um trecho dessa narrativa do corpo que não se pretende uma "arqueologia" ou busca de origem. Concentramo-nos em um primeiro momento em O corpo impossível de Eliane Robert Moraes, textos não-ficcionais de Georges Bataille e em passagens do Manifesto do Surrealismo de Breton para argumentar o caso da pertença da questão do corpo a uma lógica metafísica da presença e, portanto, descontrutível.

Focaremos em suas predicações para empreender uma checagem de seu espaço geral de acontecimentabilidade e proporemos que o entendimento do corpo, seja conceitual ou meramente referencial, sempre se passa por uma metonimização do sujeito. Esse é seu defeito de linguagem. Concluiremos, nesse trabalho somente em parte, que é preciso investigar se a História relegou o corpo ao mesmo espaço em que Derrida observou ter sido colocada a escritura.

Em um segundo momento, proporemos Jacques Derrida e Jean-Luc Nancy, também Deleuze \& Guatarri, como os contrapostos teóricos do grupo que Courtine \& Vigarello e Eliane Robert Moraes aqui representam o todo. Mais além: proporemos que Safo de Lesbos no período arcaico da Grécia antiga, e, em parte, todos os poetas mélicos, colocam-se em um plano geral de composição como respostas avant la lettre aos estudos sobre corpo. As percepções ali sobre corpos permitem, cotejadas às possibilidades figurativas do corpo em Safo, uma contestação do estatuto histórico legado teoreticamente ao corpo e indicam a uma pertença primeiramente escritural dessa questão. Isso indica a anterioridade da literatura no tratamento dessa 
questão. $O$ tratamento escritural do corpo não somente deve inspirar um pensamento teorético a respeito do tema, mas deve-se ver como o pensamento ali acontece enquanto "respostas antes das perguntas".

O estatuto fragmentário do corpus sáfico desencobre uma noção fragmentária de texto e será levado a cabo nesse trabalho com auxílio das figuras de marca, inscrição, escritura e arquiescritura. O corpo "fragmentado" que Eliane Robert Moraes vê desmontar-se no entre-guerras europeu junto à lentamente percebida frustração do projeto modernista nos permitirá propor que a fragmentação do corpo é interpretada cegamente como espelhamento do esgarço das ideias de individualidade e subjetividade históricas.

Concluiremos (claro que aqui uma conclusão um tanto apressada) que isso é reduzir a singularidade (e portanto alteridade) do corpo a figuras do Mesmo. Desde já gostaríamos de ressaltar a similitude desse movimento aos discursos de Husserl e de um Descartes husserliano ("personagem conceitual" em Meditações cartesianas...) sintetizados na máxima de "corpo é natureza", o mesmo entendimento fenomenológico de alteridade ao menos em Husserl.

A literatura, no entanto, propõe um pensamento sobre o corpo antes mesmo de ser literatura (essa concepção implica em teorizações e depende de preceitos conceituais tais como "consciência", "intencionalidade", "querer dizer", "autor", "contexto". Todos esses dependem de uma soberania e de um sistema de manutenção da metafísica). Com a lírica arcaica, com Safo, senão literatura, há inscrição "de sentido", há devir de significação. Isso recoloca a lírica em um espaço (não canônico ou "literário", pois, para tanto, seria preciso uma soberania apenas modernamente concebida) de anterioridade às formulações teóricas sobre o corpo e a possibilita ser vista, senão como literatura avant la lettre, como herança da literatura.

Para um primeiro passo em propor que o corpo passa por um esquecimento pelo pensamento especulativo, semelhante ao que vê Derrida em Heidegger quanto a um humanismo de fundo em sua obra e por isso a continuação da metafísica, Heidegger et la question de l'être servirá de inspiração para empreendermos um projeto que visa associar a negação "modernista" do humanismo com uma afirmação sobrelevada de um humanismo melhorado, que resiste na questão da "fragmentação do corpo". Esta não é um retorno à vida sensível (como quer Eliane Robert Moraes) para 
desistir das "saídas" comunistas e humanistas fracassadas, mas sim uma repetição logocêntrica de humanismo que se espelha em corpos e figuras monstruosas. 


\section{CAPÍTULO I}

Comunidades 


\section{O problema da comunidade em questão}

\section{A comunidade de Blanchot}

Em La communauté inavouable Blanchot nada promete de seu livro além de uma breve reflexão "concernente à falha de linguagem que tais palavras como comunismo ou comunidade parecem conter, se pressentirmos que carregam algo completamente outro que o que poderia ser comum àqueles que pertenceriam a um todo, a um conselho, um coletivo, mesmo quando negam pertencer a ele, qualquer seja a forma em que neguem" ${ }^{4}$. Sair do livro com respostas do que é uma comunidade, seus processos e a que propriamente se refere essa palavra quando se a menciona está fora do campo de previsibilidade do que é proposto pela obra. O que Blanchot realmente nos proporciona é algo como uma experiência da pergunta.

"Comunidade está fora da inteligibilidade", começa-se já nos tirando de vista o que quer que pudesse ser um objeto de pesquisa concernente ao pensamento especulativo ou científico, que acostumou-se a responder suas perguntas. Eis aí os inícios de uma comunidade negativa, mais tarde no livro tratada pormenorizadamente; a comunidade, por não pertencer ao campo da inteligibilidade, não é demonstrável ou de fato cognoscível, seus "defeitos de linguagem" apenas nos "parecem [...] se pressentirmos".

Os conceitos que estão ao redor da "comunidade", do "comunismo", talvez se refiram ao mesmo, apenas em diferentes níveis. Como previsto em Nancy, eles estão além da ruína histórica, são defeituosos por causa de seu abandono. Blanchot ainda insiste em chamar essas palavras de conceitos, das quais observa, "aparentemente", um defeito de linguagem e, senão por causa da terrível ruína e dos restos de fracasso que deixaram a nós historicamente, algo ainda resiste neles de um abandono tout court.

Se Nancy declara ser Rousseau o primeiro pensador da comunidade,

\footnotetext{
${ }^{4}$ Blanchot, Maurice. La communauté inavouable. Paris: Les Éditions de Minuit, 1983, p.9-10. Trad. minha.
} 
em La communauté inavouable, Blanchot fundamenta-se em Morin "comunismo" como possibilidade de uma outra sociedade, outra humanidade e diz:

O comunismo, ao dizer que a equidade é seu fundamento e que não pode haver comunidade até que as necessidades de todo homem sejam igualmente preenchidas (isso é em si senão um requerimento mínimo), pressupõe não uma sociedade perfeita, mas o princípio de uma humanidade transparente essencialmente produzida por si mesma, uma humanidade "imanente" (diz Jean-Luc Nancy). Essa imanência do homem ao homem também aponta ao homem como 0 ser absolutamente imanente pois ele é ou tem que se tornar esse homem tal que ele possa inteiramente ser uma obra, sua obra, e, no fim, a obra de tudo ${ }^{5}$.

"Aí está a aparentemente saudável origem do mais doente totalitarismo" ${ }^{6}$, conclui. Colocando-se enquanto fundamento do comunismo um certo humanismo de fundo, tem-se um comunismo definido classicamente, quer queira também a comunidade definida da mesma forma: enquanto atualização a si de um trabalho de que é o resultado final e ao mesmo tempo o impulso. A comunidade é sob essa ótica o "trabalho" de si mesma, o homem enquanto obra de sua propriedade agrupa-se num desejo de "obra" que é sua própria essência, atualizada numa essência comunitária.

A humanidade transparente é uma comunidade transparente de si à sua obra, que é extensão de seus indivíduos, pois é a essência comum produzida comunitariamente. "Ser inteiramente sua obra": eis aí a sua imanência. Na medida em que é presença pura de si para si, essa comunidade não pode ser feita senão de indivíduos. Isso porque o "trabalho", a "produção", ou mesmo o "sentido" que atualizam, a si e para todos o mesmo, só pode ser referido ou reportado à parte de que se estendem. O "trabalho" é inalienável do indivíduo, e é isso que invariavelmente o torna um sujeito.

O indivíduo afirma-se com seus direitos inalienáveis, sua recusa de ter qualquer origem senão ele mesmo, sua indiferença a qualquer dependência teorética em relação a outro que não seria um indivíduo como ele, isto é, em relação a ele mesmo perpetuamente repetido, seja no passado ou no

\footnotetext{
5 Id. Ibid., p.11

${ }^{6}$ Id. Ibid., p.11
} 
futuro - portanto tanto mortal e imortal: mortal em sua inabilidade em perpetuar a si mesmo sem alienar-se; imortal por que sua individualidade é a imanência de vida que não tem limite em si mesma ${ }^{7}$.

A raiz mais extrema da comunidade definida enquanto "obra" de um agrupamento de indivíduos cuja humanidade é repetidamente asseverada enquanto "trabalho final", no entanto sempre em processo, é reconhecidamente o indivíduo. Trata-se aqui de uma relação primordial entre o entendimento social e político de uma comunidade enquanto seguimento lógico do indivíduo, o átomo indivisível que, matematicamente, se soma a outros átomos, formando um simples agrupamento de agregados cujas partes são privadas de outras partes (a-tomo).

Deixe-se ressaltar que a observação da comunidade enquanto fenômeno social, político ou mesmo "intersubjetivo" é notadamente a primeira a resistir uma fenomenalização pelo justo axioma de sua pertencença a algo outro que não ao campo da inteligibilidade. Essa resistência à fenomenalização de fundo metodológico caminha junto de uma resistência da parte dos indivíduos - que compõem uma certa comunidade suspensivamente factual de proporem sua própria individualidade, "a imanência de vida", enquanto limite de si mesma em cada individualidade conformadora.

É certo que há duas "comunidades" em La communauté inavouable. Uma é como que a explicitação do que se tem enquanto ranço de um comunismo fracassado e de certo humanismo. Outra é a tentativa de entendimento do que teria querido Georges Bataille com suas obras ficcionais, quando se deixa espantar pelas concepções de "comunidade", "experiência interior", "êxtase", "comunicação", "erotismo" etc. Quanto à segunda, aí vemos que a literatura, os textos narrativos de Bataille, é responsável por responder às perguntas feitas apenas posteriormente pelo pensamento teórico.

Bataille teria sugerido uma comunidade, que não se deixa pensar fora de uma comunidade literária ou comunidade entre leitores e escritor. Em princípio, somente Nancy aponta para uma comunidade escritural,

${ }^{7}$ Id. Ibid., p.11-12 
permanecendo fiel aos textos literários de Bataille. Em La communauté desoeuvrée, ele menciona que a comunidade não se dá senão por uma inscrição. A concepção de escritura de Jacques Derrida é "toda e qualquer inscrição" que seja e Jean-Luc Nancy compartilha do léxico derridiano. A inscrição, que não se atém somente à letra, põe em jogo sentidos em devir através da différance e funciona como alternativa à concepção estruturalista de "literatura". Quando Nancy põe a inscrição em um imperativo a priori para a comunidade, o que temos é que, segundo Nancy, a comunidade é primeiramente escritural.

Contudo, mesmo a comunidade a que Blanchot se aproxima via Bataille não está ainda indeterminada de "obra". Isso porque ela ainda resiste em uma individuação qual seja.

\section{princípio de insuficiência}

O indivíduo cuja "individualidade é a imanência de vida que não tem limite em si mesma" é por isso imortal; e também, pois, mortal "em sua inabilidade em perpetuar a si mesmo sem alienar-se"8. Estão aí em jogo dois movimentos similares. A mortalidade é justificada pela inabilidade em continuar sem alienação; perpetuar-se sem sair de si, sem exceder-se em um outro ou perder consciência plena de seu "trabalho" ou daquilo em que participa na feitura de comunidade, na comunidade.

A imortalidade, por sua vez, é a "imanência de vida" que encontra seu limite além de si. Mais uma vez, o indivíduo, que terá no "sujeito" sua autossuficiência e liberdade privativa, é predicado em sua essência, a individualidade, enquanto excesso e perda do que o define mais propriamente, seus limites indivisíveis, sua finição, para a externalidade impredicada.

"Existe um princípio de insuficiência na raiz de cada ente..." (o princípio de incompletude). Deixe-nos tomar nota que o que comanda e organiza a possibilidade de um ente é um princípio. Segue-se que essa falta em princípio não caminha junto com uma necessidade de completude. Um ente, insuficiente tal como é, não tenta associar-se com outro ente para formar uma

${ }^{8}$ Op. cit., p. $11-12$ 
substância de integralidade. A consciência da insuficiência vem do fato de que se coloca em questão, questão essa que necessita o outro ou um outro para ser encenada ${ }^{9}$.

Se o indivíduo tem seus limites, confins e términos, há que se permitir que também tenha um princípio. Nos dois sentidos que pode tomar essa palavra, o princípio que começa e o princípio que rege, o indivíduo é aqui tomado enquanto ente. O princípio de insuficiência radical dos entes não os fundamenta enquanto faltantes de uma soma posterior. Numa dialética pressuposta, seria sem surpresa dizer que algo que é de nascimento incompleto espera sua completude de algo outro, posteriormente.

No entanto, é assegurado que o princípio de incompletude não se serve para uma justificativa ou entendimento da comunidade enquanto preenchimento de faltas pelos outros que formam suas partes. A comunidade não é, segue-se disso, uma integralidade, uma "substância de integralidade" cujo agrupamento de insuficiências as completaria num indivíduo (a unidade íntegra) per se. Pela questão da comunidade, ela mesma sendo uma insuficiência de partes predicadas como "indivisíveis", é que se percebe o "princípio de insuficiência" na raiz do ente, ao fundo do indivíduo também. Este último, no entanto, continua indivisível em sua falta incompletável, isto é, apesar de qualquer falta, insuficiência, essas não se abrem à um preenchimento, a uma completação.

O que se vê aí de fundo, e o que queremos propor fundamentalmente é que o esgarçamento do indivíduo, sua insuficiência e suas faltas não passam de princípios régios de fundamentação de sua "readaptada" integralidade. "Um ente, insuficiente tal como é, não tenta associar-se com outro ente para formar uma substância de integralidade" ${ }^{10}$.

Se um ente em sua insuficiência arraigada não precisa, contudo, de um outro ente para completar-se a "uma substância de integralidade", é porque não precisa de um outro mesmo, mas um outro Outro. Essa abertura a um outro não pode ser preenchedora, senão mais desestabilizadora do mesmo, do Ser, do ente. Essa "questão" que precisa do "outro para ser encenada",

\footnotetext{
${ }^{9}$ Id. Ibid. p. 15.

${ }^{10}$ Op. cit. p. 15
} 
contudo, não desestabiliza o mesmo, não o faz "ganir diante do Nada"; somente coloca o Mesmo frente ao outro, e não o Outro frente ao mesmo. De fato, o outro serve ao Mesmo para que este último se coloque em questão.

\section{A comunidade não é uma soma de unidades}

"Deixado só, um ente se fecha, dorme e se acalma. Um ente está ou sozinho ou se sabe sozinho apenas quando não está" ${ }^{11}$. É ainda no agrupamento que nega a solidão que se percebe a solitude do ente. Se é apenas quando não se está que se sabe sozinho, é porque o ente, não menos solitário, se econtraria rodeado de outros entes, sejam esses indivíduos, numa qualquer comunidade.

A comunidade, começa-se a perceber, não significa "juntar" os sozinhos para fazê-los acompanhados em relação à obra que os qualifica enquanto comunidade. Blanchot nos mostra que só é comunidade se e porque a "obra" que organiza e assimila seus partícipes é justamente a mesma que os une e invariavelmente os separa na partilha de uma solidão.

A figura da separação em um pensamento da comunidade é importante na medida em que essa define a relação entre comunidade e indivíduos - no sentido que assume essa palavra enquanto base para um pensamento sobre "entes", que acontece em termos de uma individuação progressiva e em estratos, de cima a baixo, numa conformação situacional. $O$ indivíduo é radicalmente separado de tudo que lhe é outro.

A questão do indivíduo e da comunidade - e a aparente relação sem laços que aí se dá, uma relação não relativa pois não fundamentada no princípio de uma dependência nem de uma privação, como é questionado por Jean-Luc Nancy nas figuras de liberdade e suficiência - dizem ambas respeito à imanência enquanto questão geral.

Uma comunidade não funcionaria de todo contrariamente à imanência de que predica sua "obra" humana, logo, não seria a imanência de que propriamente a comunidade é questão uma transcendência programada e inatual quando o caso é uma comunidade inoperante? De fato, a passividade ${ }^{11}$ Id. Ibid. p. 16. 
que assombra Blanchot não toma proporções de não-produção de essência na comunidade inoperante de que fala, pelo contrário, essa passividade, de que não se fala explicitamente mas sobredomina a obra, pode ser entendida de outra maneira: a partir dela a comunidade inoperante se torna produtora de inessência, inoperância enquanto produção de ausência.

Nesse sentido, a comunidade inoperante blanchotiana não é nãooperante, produtora de nada ou nenhuma obra. Ela não é indeterminada ou desapropriada. Ela ainda tem propriedade e determinação. Isto é dizer que ela ainda implica uma ontologia. Ela opera e produz in-essência. Isso porque para Blanchot a obra não é feitura de um resultado final e atual, fático. A obra opera desde um centro de ausência, mas ainda desde um centro. Ela é impossibilidade de atualização, de completar-se. Mas essa é sua essência. Suas produções e operâncias são predicadas a partir de figuras de inessência. Assim o "branco", o "vazio", o "silêncio", a "noite".

Por isso a comunidade blanchotiana também advém de um gesto literário. Ela tem sua fonte no pensamento figurativo. É desdobrada por metáforas, imagens, elementos plásticos que engendram um pensamento argumentativo.

Pode-se predicar a ausência enquanto "obra" de uma qualquer comunidade sem que deslinde a "obra" por uma noite comunitária cuja escuridão é partilhada em indivíduos invisíveis de seus limites? Isso seria o esperado. No entanto, o que acontece em La communauté inavouable está longe de uma partilha de ausência entre deslimites.

Os participantes da "comunidade inconfessável" são ainda indivíduos, entes que estão bem demarcados em suas individuações e limites. O que acontece é a incomunicabilidade de uma experiência faticamente partilhada entre indivíduos. Isso é dizer que La communauté inavouable, portanto, passa pela questão da imanência; o que é questionado é a comunicabilidade da experiência, é a inessencialidade da produção de sentido entre os entes, a partilha enquanto distribuição de ausência entre indivíduos.

O que não é questionado, no entanto, em La communauté inavouable é: 
1) O limite enquanto pressuposto necessário para a experiência (experienciação) e a comunicabilidade à qual também está intricada, na medida em que a comunicabilidade é pressuposto da experiência (e vice-versa) Bataille proporciona pensar na incomunicabilidade da experiência a partir do êxtase, que é necessariamente uma não-experiência devido à saída de cena do conceito de limite, que inexiste numa abertura para a exterioridade que equivale o dentro ao fora como o é no êxtase;

2) A alteridade enquanto aporia do limite; se a comunicabilidade pressupõe a alteridade, em que o limite afeta a alteridade no caso de uma incomunicabilidade por ausência de limites ao indivíduo, que propriamente desfaz-se no êxtase? Isto é: como pode o limite ser pressuposto da experiência (e, por tabela, da comunicabilidade que pressupõe a experiência e vice-versa) ao mesmo tempo em que a experiência pressupõe e necessita a alteridade (assim como a comunicabilidade)?

Essa questão se complexifica quando se leva em conta o incômodo que causa a Blanchot o pensamento de uma comunidade ainda afastada de "obra". Certo que essa é uma concepção blanchotiana, mas talvez Nancy a tenha compreendido melhor em seu La commuanuté desoeuvrée, em que a distinção entre indivíduo e alteridade é feita claramente. Em Nancy há talvez uma resistência à noção de indivíduo, de membros de uma comunidade, pois ele questiona a própria noção de limite, de limites, portanto, que constituem uma individuação.

Nancy nos lembra que a comunidade inoperante só pode ser constituída de singularidades. A noção de singularidade é semelhante à de alteridade, à qual não cabe divisibilidade. Que a comunidade seja, no trabalho de Blanchot, constituída de indivíduos, faz necessário, cabal mesmo, que os indivíduos tivessem produções a seu alcance, extensões de si mesmos e entendimentosde-si que constituíssem a produtividade de sua essência comunitária. Esse é o próprio pressuposto de indivíduo. Sua indivisibilidade vem com um direito a suas extensões, um entendimento de si pelo seu trabalho, portanto implica em "obra". 
O fato é que Blanchot parece estar ainda arraigado em uma noção individuada de comunidade. Está claro que seu entendimento de "comunidade" insiste em uma "supraindividualidade".

\title{
Comunidade e individuação: imanências
}

\begin{abstract}
"O que estou pensando eu não pensei de todo sozinho". O que temos aqui é um entrelaçamento de motivos dissimilares que não garantiriam uma análise, mas cuja força reside na mistura de diferenças associadas. É como se pensamentos que podem ser apenas pensados juntos se juntassem em volta de uma catraca, sua multiplicidade mesma dificultando qualquer passagem $^{12}$.
\end{abstract}

Não é incomum que a singularidade enquanto conceito resvale-se às figuras da alteridade numa coextensividade conceitual que é ao mesmo tempo figurativa. Nancy entende singularidade e alteridade como indiferentes. $\mathrm{Na}$ passagem de Blanchot acima, no entanto, "pensamentos que podem ser apenas pensados juntos" se agrupam ao redor de uma catraca e a multiplicidade que os torna propriamente múltiplos impede que passem e completem a ação para que se juntaram ali.

É aceito que uma catraca tem seu design pensado junto à unidade que é seu propósito de uso e justificativa de uma certa morfologia funcional. Não é certo que a força que "reside na mistura de diferenças associadas", esse "entrelaçamento de motivos dissimilares" cuja força ainda resiste uma análise, impediria-os à quebra perpetrada por uma qualquer divisão de suas partes, mantendo-os impensavelmente unidos, mas ainda sim resistentes também à pluridade?

A imagem de uma catraca não acabaria, portanto, por positivar uma certa unidade ao "pensamento"? É certo, todavia, que esses pensamentos não conseguem passar pela catraca, mas, em vez de não conseguirem por não constituírem unidade, não conseguem porque são muitos. A "multiplicidade

${ }^{12}$ Id. Ibid. p. 16. 
mesma" é que dificulta a passagem ${ }^{13}$. O conceito de unidade é ainda regulador em Blanchot pois que, p. ex., "multiplicidade" do pensamento não pode senão referir-se a uma série finita e, portanto, numerável e definível.

Ou mesmo: um pensamento que necessitaria de uma coletividade, ou ao menos de uma não individualidade, poderia ser sequer pensado ${ }^{14}$ ? Não acabaria ele por predicar o múltiplo à individualidade e unidade à alteridade mesma? A multiplicidade dos pensamentos pensados juntos ainda não é o princípio de comunicabilidade que os rege desde a alteridade que é o pressuposto da comunicação. Contrariamente, o pensamento será em Nancy um conceito cujo pressuposto é a alteridade (com valor de singularidade) que resiste à comunicabilidade e que necessita de uma concepção única de espacialidade ${ }^{15}$.

Incontáveis são os esquemas que pretendem programar dentro à sistematicidade do pensamento demonstrativo algumas relações de fraternidade eidética entre os temas aqui expostos.

\footnotetext{
${ }^{13}$ Reporto aqui à ressalva que faz Derrida quanto a seu "conceito" de différance. Este último diferencia-se por completo de uma polissemia, pois que a polissemia é constituída de partes unitárias derivadas de um significado preferido e anteposto às outras possibilidades de significação, que podem ser estabelecidas em seu número e relação ao significado comum e dicionarizado; é certo que tais possibilidades podem inclusive se constituir como desvios, sentidos figurados, regionais etc. Já a différance é predicada somente metafórica e figurativamente. Ela é uma "tessitura" cujo trabalho não se pode parar, ela é um devir de significação que, no entanto, não pode ser predicado como tal. Seu processo é impossível que seja parado pois suas limitações são o horizonte de possibilidades da "obra", que se mantém entre finição e infinito. Portanto, para a polissemia, há uma regulação da parte de um conceito de unidade que mantém os significados numeráveis (porque tornados signos) e estabelecíveis. Para, contudo, a différance, não há conceito regulador de unidade e essa é de fato sua singularidade. Para um aprofundamento da questão da différance e da disseminação e suas relações com escritura, traço e rastro: La dissémination, Seuil, 1972; Marges de la philosophie, Ed. Minuit, 1972. Para trechos dialogados sobre esse tema: Positions, Ed. Minuit, 1972. Para a especificidade da différance, em Van Gogh e nas artes "plásticas" de modo geral, La vérité en peinture, Flammarion, 1978.

${ }^{14}$ É certo que a questão do pensamento e sua diferença à escritura está na seara de Artaud. Em termos analíticos, pode ser dito que em $O$ pesa nervos ele se questiona se é possível pensar um pensamento pelo suporte escritural. A figura de um abismo que se coloca entre o pensamento e sua expressão "estética", em desenho ou em palavras (ambos para Derrida constituem inscrição e portanto escritura), é o que conta no questionamento de Artaud, que terá, talvez, alguma resposta em Nancy e sua figura de limite intocável, com o jogo etimologizante entre pensée e pesée.

${ }^{15}$ Para essa questão: Le toucher - Jean-Luc Nancy, Ed. Galillé, 2000.
} 


\section{Figuras de coletividade: "espírito", desde os átomos}

Com o que se segue, pretende-se demonstrar o funcionamento da ideia de Aufhebung e como ela implica em uma metafísica. De fato, ela é um processo de manutenção metafísica. Isso significa dizer que ela opera e faz manejo ao serviço de uma lógica do Mesmo. Pretende-se com isso aproximar o apego de Blanchot à individualidade como uma permanência no logocentrismo da ipseidade, isto é, um reestabelecimento da violência do Mesmo. Para isso, analisa-se a "supraindividualidade" de que Blanchot predica a comunidade inconfessável como uma figura de sobrelevação (Aufhebung) e melhoramento da individualidade.

A comunidade em Nancy é uma abertura. Ela é também um entendimento ontológico, seu assunto é, enfim, o ser-comunitário; no entanto, ela propõe um pensamento ontológico da singularidade, e não do indivíduo.

O "espírito" hegeliano é uma individualidade coletiva - um "Eu" que é um "Nós" ou mesmo o contrário - e não um conjunto de individualidades. Ele questiona a própria questão de uma multiplicidade unitária e uma unidade que pode ser múltipla, revendo em estado de dúvida tanto sujeito quanto sociedade.

A "comunidade inconfessável" de Blanchot sem dúvida não é tão facilmente explicada como um "conjunto de individualidades" e certo está que declará-la símile do "espírito" hegeliano talvez necessite um melhor explicitamento do que quer que "espírito" tenha significado mesmo para Hegel, o que permance, sem dúvida, a ser feito. Contudo, percebe-se ainda em Blanchot a permanência de uma unidade atrás das figuras de multiplicidade.

É necessário no entanto esclarecer que o Absoluto e o "espírito" a que é por vezes equivalente, em Hegel, não constituem o mais geral do pensamento dialético ${ }^{16}$. O "espírito" é, e não é, o resultado final de um processo. Por tratarse de uma dialética transcendental, o último estágio de pensamento é também o mais "puro" e mais "originário". Isso o torna produto metodológico de um pensamento cujo resultado é o começo mais originário e possibilidade de

${ }^{16}$ Cf. Quentin Lauer. A reading of Helgel's Phenomenology of spirit. NY: Fordham University Press, 1993. 
qualquer pensamento que seja. Tendo em vista o "didatismo" dos estados sugeridos por Hegel como mais próprios de um sistema que desse conta de todo outro sistema, o fim que é o começo, se torna um tanto mais claro. As etapas que constantemente rejeita e profere falhas são substituídas por outras e outras até que se esteja satisfeito com um tipo de sistema.

A batalha das consciências, um dos estados sugeridos por Hegel, pode ser explicada primeiramente no que tem de batalha além do nome. Figura-se uma situação tal que uma consciência - que num primeiro momento resiste o nome de "sujeito" - econtra-se consciente de um objeto de que é consciente. Toda consciência requer uma transitividade desse tipo. O objeto de que é consciente por sua vez também é uma consciência. Ambos são autoconscientes e lutam para posicionarem-se numa hierarquia entre senhor e servo.

Essa é uma das interpretações da cena. Há uma outra, em outro nível. Como cada uma das consciências é autoconsciente, trava-se internamente uma outra batalha ao nível "psicológico": toda consciência é ciente de alguma coisa. Nesse caso, o caso da autoconsciência, há que se estabelecer, se se quiser manter o léxico "sujeito", "objeto", "consciência" e os esquemas que dele se segue, um sujeito e um objeto. Para uma autoconsciência que é ciente de si mesma, ela é ao mesmo tempo sujeito e objeto; primeiramente, no entanto, cria-se duas consciências, mas uma deve morrer e tornar-se objeto da outra.

\section{amor e o desejo, Aufhebung}

Uma certa análise da cena da "batalha das consciências" não deve apressar-se em tratá-la enquanto faticidade de batalha ou como dados fáticos de uma consciência qualquer; trata-se, muito provavelmente, de uma cena, isto é, uma dramatização didática, adicione-se. O seguinte trecho de La communauté inavouable lembra uma das etapas a serem superadas (aufheben) no caminho dialético empreendido por Hegel, a "batalha das consciências", que, ao mesmo tempo, é a figura da própria superação, denegação, sublevação, rélève (Aufhebung) por que se deve guiar. 
Um ente não quer ser reconhecido, quer ser contestado: para existir vai em direção ao outro, que o contesta e por vezes o nega, para então começar a ser apenas naquela privação que o torna ciente (aqui jaz a origem da sua consciência) da impossibilidade de ente em si, de subsistência enquanto seu ipse ou, quer queira, como ele mesmo enquanto indivíduo separado $^{17}$.

A descrição acima de um "indivíduo" separado encaixa-se perfeitamente à "batalha" hegeliana de consciências. O trecho "um ente não quer ser reconhecido, quer ser contestado" chama atenção pelo uso do verbo querer. Trata-se portanto não de um dever, mas de um desejo ${ }^{18}$.

Tomemos o trecho em Blanchot do ente que "para existir vai em direção ao outro, que o contesta e por vezes o nega, para então começar a ser apenas naquela privação que o torna ciente". Ora, para Hegel é aí que jaz a origem da consciência e que toma, em Kojève, o estatuto de um "desejo de preenchimento" que acontece através ou apesar de uma denegação pela privação. A consciência aflora-se apenas na total independência de objetos do consciente, que não passaria de um objeto também por ser essa a propriedade qualitativa de objeto. Já para Kojève, a dominação do objeto pela consciência que o hierarquiza inferiormente é somente compreensível pelas imagens eróticas de "preenchimento do vazio" e "desejo."

Teria Bataille figurado em seus textos o erotismo de que para uma "fenomenologia da consciência" kojèviana é o princípio? Com o acima exposto, quer-se novamente ressaltar a importância da literatura na medida em que é a partir dela que surgem as questões. Mesmo se se diz que Bataille teria figurado

\footnotetext{
${ }^{17}$ Id. Ibid. p. 16.

${ }^{18}$ Alexandre Kojève já reconhecidamente tratou da figura do desejo e de sua importância em Hegel, principalmente na cena das consciências. Kojève foi importante figura na introdução de Hegel à França no sec. XXI e a importantes pensadores contemporâneos franceses. Georges Bataille, entre eles, atendia a seus seminários sobre Hegel na École Pratique des Hautes Études de Paris durante os anos 33-39 que trataram da leitura de Fenomenologia do espírito. O pensamento de Bataille é estudado em Blanchot e Nancy com o estatuto de epígrafe. É inclusive notória a "influência" de Kojève nos trabalhos "literários" de Bataille como por exemplo a História do olho em que o "desejo de preenchimento" de que trata Kojève conceitualmente em Introdução a Fenomenologia do espírito é como que reconfigurado em plasticidade estética e narrativa na obsessão pelo personagem batailliano a quem assombram as imagens de branco e vazio.
} 
Kojève, a questão complexifica-se e em muito ultrapassa o pensamento teórico pois basea-se na figuração e na imagem, portanto abertura de sentido, e não definição de fechamento.

\begin{abstract}
Uma comunidade é historicamente de poucos números e aponta para uma efeverscência juntando os elementos apenas para dar nascimento a uma unidade (uma supraindividualidade) que se exporia às mesmas objeções vindo da simples consideração do indivíduo único, fechado em sua imanência ${ }^{19}$.
\end{abstract}

Aqui Blanchot prepara uma transição da comunidade pensada enquanto agrupamento para uma comunidade entre dois, o casal ou os pares. É interessante notar que há alguns tons de hegelianismo ainda presentes. No trecho "dar nascimento a uma unidade (uma supraindividualidade)", pode-se relacionar ao "espírito" a supraindividualidade nascida da efervescência ${ }^{20}$. A comunidade blanchotiana é invariavelmente afastada de sua própria imanência pelo movimento de uma "sobrelevação" a uma unidade que se autosuprimiria em sua possibilidade de presença. O que a comunidade inconfessável partilha de comum entre seus indivíduos é de fato "fala, silêncio". Retornamos à questão de uma comunidade que distribui ausências para confirmar que a comunidade é ainda definível a partir de uma divisão entre seus indivíduos, e que há individuações de certo pelos entes que a constituem. A partilha no entanto fica como que inefetuada ou inefetuável pelo fato de que aquilo que é partilhado ser "incorpóreo" ou inindividuável.

\title{
Comunidade e inscrição, para escrituras
}

O que então chama-me à questão o mais radicalmente? Não minha relação a mim mesmo como finito ou a consciência de

\footnotetext{
${ }^{19}$ Id. Ibid. p. 17

${ }^{20}$ São palavras de Blanchot que ecoam uma certa Aufhebung da comunidade: "Donc, [...] la communauté n'a pas à s'extasier, ni à dissoudre les éléments qui la composent en une unité surélevée qui se supprimerait elle-même, en même temps qu'elle s'annulerait comme communauté" (Op. cit., p. 19).
} 
ser-ante-a-morte ou para-a-morte, mas minha presença para o outro que se ausenta morrendo. Permanecer presente na proximidade de outro que por morrer remove-se definitivamente, tomar para mim mesmo a morte do outro como a única morte que me concerne, é o que me põe à parte de mim mesmo, é a única separação que me pode abrir, em sua impossibilidade mesma, à Abertura de uma comunidade ${ }^{21}$.

"O que [...] chama-me à questão o mais radicalmente" é certamente um momento do texto em que Blanchot propõe a morte como uma figura de alteridade que, no entanto, não é ainda Outro, senão outro, pois é o que chama o Mesmo à questão "mais radicalmente". Para Heidegger a Abertura ${ }^{22}$ é, finalmente, o que põe o Dasein em questão, portanto serve ao Mesmo. Heidegger, portanto, nos mostra que a propriedade última do Dasein, o que mais o concerne e também o que o acorda para um entendimento-a-si radical, é justamente o chamado à questão que o tira de sua queda; a radicalidade e as palavras do léxico da "raiz", fundamento, "fundo" e "base" apenas ressaltam uma pertença do tema, às voltas em Blanchot e Nancy, ao pensador alemão.

Também é nesse trecho acima que se vê primeiramente a aparição da palavra "abertura", que, junto a "clareira" e outras imagens como "ponte", p. ex., formam a rede de sentido que na obra heideggeriana é operante conceitualmente e faz um trabalho semântico de fundo, passando-se incógnita como jargão técnico ${ }^{23}$.

\footnotetext{
${ }^{21}$ Id. Ibid. p. 21

${ }^{22}$ Uma das leituras prevalentes para a "abertura" heideggeriana é que consiste em uma figura de alteridade. Enquanto abertura ao outro. No entanto, a abertura em Heidegger é o que mais chama o Dasein à questão de si mesmo. Atualiza-o frente ao mundo (Nancy nos lembra que "o indivíduo é um mundo", e que, portanto, o mundo é individuação). A abertura, por isso, serve ao Ser, ao Mesmo, o ipse. Ela não abre portanto à alteridade, mas altera o Mesmo em outro mesmo.

${ }^{23}$ Blanchot aqui ecoa um certo Heidegger. O "ser-com", cujo "ser-no-mundo" só se dá presentemente à atualização-a-si (e adiantamento de uma possibilidade ausente) de um entendimento-de-ser frente à morte, o que, com Blanchot, toma nova importância de revisão do projeto heideggeriano paralelo ao conceito de comunidade. Em Heidegger também o ser-finito é originariamente determinado pelo ser-com seu modo de ser mais originário e geral. A importância do "ser-com", e consequentemente do projeto heideggeriano, para a questão da comunidade é difícil de explicar sem uma análise que se detivesse majoritariamente nessa questão. Por hora as palavras de Nancy são suficientes: "A comunidade não cria laços de uma vida imortal, transmortal ou mais além entre sujeitos [...] É constitutivamente [...] ligada à morte daqueles que se chamam, talvez erroneamente, seus membros" (1990, p. 41). Talvez mais claramente ainda seria dizer que a comunidade é anterior ao indivíduo. A comunidade é figura mais geral do "ser-comunitário"/ser-com-unitário que se acentua mais expressivamente na morte enquanto propriedade partilhada entre os seres e organizadora de suas vidas em
} 
O que mais radicalmente "chama-me à questão" é "minha presença para o outro que se ausenta morrendo". Eis o problema da imanência, que é propriamente a questão para a comunidade. Em "permanecer presente na proximidade de outro que por morrer remove-se definitivamente", tem-se a questão da comunidade levada à inscrição do luto, que tanto pela substituição ou pelo abismo entre a necessidade lógica de uma substituição e sua atualidade impossível pela singularidade da perda, fazem para-a-comunidade uma inscrição de sentido em que "sentido" é o último sentido enquanto chegada, o ponto de basta que organiza tudo. Ainda não se vê, contudo, e talvez só se o veja em Derrida, a morte como figura de alteridade que não é numa atualidade, e sim, num porvir messiânico em que não há atualização da vinda.

A inscrição da morte enquanto inscrição comunitária em discrições ou segmentos de intervalos vitais para os viventes torna o outro, sempre o outro, "o único a possibilitar [...] ao menos a súplica à fala que carrega consigo o risco de rejeição ou perda ou não recebimento" ${ }^{24}$. É desde o dom da fala enquanto advindo de e indo ao outro ou o outro enquanto doador da morte, pois que o dom e morte se inscrevem pela alteridade, que pressente-se que "[...] a comunidade, em seu próprio fracasso, está ligada com uma certa forma de escrita, uma escrita que não tem nada a mais para procurar senão as últimas palavras"25.

No entanto, já se havia dito que a comunidade não tem trabalho e que não se une num trabalho que é a atualização de seu sentido-a-si ou consciência de valor ou propósito. Como então conceber uma total ausência de obra e produção ao entendimento da comunidade como uma substância originária como um paralelo com Heidegger o faria ser necessário? A substancia originária em uma ausência não conformaria no entanto ainda uma obra? Novamente com Blanchot é dito, talvez um tanto peremptoriamente nesse formato de citação, que "Cada membro da comunidade [...] é [...] a [...]

medidas de sentido realizáveis em individuações ou conformadoras de individuação desde que findem.

${ }^{24}$ Id. Ibid. p. 26

${ }^{25}$ Id. Ibid. p. 26 
encarnação impotente da totalidade de entes que, tendendo a existir integralmente, têm como corolário o nada em que já [...] caíram" ${ }^{26}$. O que suprimiu-se do trecho citado foram apenas algumas muito importantes locuções adverbiais que tornavam a frase mais cuidadosa e tentativamente afirmativa, ao passo que no formato citado tem-se quase um axioma definitivo.

O que se quer reter do trecho, e talvez aí algum traço de peremptoriedade seja requerido, se não desejado, é que o "cada" em cada membro é o instante ou estância de singularidade que impotentemente encarnada como a "totalidade de entes que [...] têm como corolário o nada em que já, e antes da hora, caíram" ${ }^{27}$, é valida enquanto individuação de uma totalidade de indivíduos numa impossibilidade ordenada que apenas a mais quadrada lógica de conjuntos invejaria em suas formas mais oblongas. Não resistimos a uma reformulação do trecho e completamente entregamo-nos aqui ao risco possibilíssimo de embaçar com a citacionalidade descuidada as frases limpas de Blanchot e intencionalidade perigando máculas.

Outrora "antes da hora", unindo-se a um "já" de antecedência, cada um de seus membros que individua a totalidade do agrupamento todo "tem como corolário o nada em que caíram". Eis que o "nada" é predicado enquanto corolário, consequência e, ao mesmo tempo "já" e "antes da hora" o transforma em princípio e pressuposto. Há interessantemente uma predicação "substancial" no nada em que caíram as instâncias de totalidade referente ao todo.

\section{Morte, figura de alteridade}

A comunidade estar-para-morte não significa unir-se em comunidade de partilha do comum de algo ou quaisquer propriedades ou qualidades que possa ter seus indivíduos, mas uma comunhão que a morte possibilita em sua impossibilidade mais pura. Na lógica sacrificial que é o tema da infinita obsessão de Bataille, a morte do sacrificado não significa acabar ou terminar, aniquilar, mas "dar-se inteiramente ao abandono ilimitado". O único segredo

${ }^{26}$ Id. Ibid. p. 28

27 Id. Ibid. p. 28 
claro e inapreensível da comunidade é sua ausência? A própria lógica do segredo nos impede transformar essa pergunta em afirmação, mesmo que estivéssemos tentados a estabelecer aqui algo como um terreno seguro, dizer afirmativamente que segredo claro e inapreensível é "ausência" é já presentificar em discurso verídico e axiomático o que não se dá senão em fuga e sombras. Em Blanchot: "A ausência de comunidade não é o fracasso de comunidade", afirma, e continua, um tanto taxativo: "ausência pertence à comunidade enquanto seu momento extremo ou como o dever que a expõe ao seu necessário desaparecimento" ${ }^{28}$.

É notória a resistência do filósofo em predicar uma substância ou propriedade à comunidade. No entanto, são usadas as palavras designadas outrora para essa tarefa: "pertence", "momento extremo", "dever", "necessário". Tais palavras põem a situação na ordem na "necessidade" numa ordem substancial que "deve" por não poder mais nada além do que o que a "pertence" enquanto "momento extremo". Uma qualquer comunidade seja atual ou utópica não pode existir enquanto tal. Comunidade só existe enquanto iminência e retirada, iminência de uma ausência ou morte mais perto que qualquer proximidade. Retirada daquilo que não permitiria retirar-se dela.

Certamente reduzir a questão da comunidade a um problema ontológico seria já trair seu segredo ${ }^{29}$. Mas propô-la necessariamente portando ausência não seria totalizar o incompleto, o nem-sequer-presente em imanência pura? Não seria, portanto, comprometer-se com uma presença de ausência? Um ente ausente? Isso nos faz referir à leitura de Penser ce que vient, em que a comunidade pode ser pensada como uma figura do que Derrida chama de messianismo. O que só existe enquanto iminência ou promessa, jamais enquanto presença pura diante dos olhos e incontestável evidência.

\section{Comunicação, passagem e partilha}

\footnotetext{
${ }^{28}$ Id. Ibid. p. 30-31

${ }^{29}$ Nancy reconhece que a questão da comunidade é também uma questão ontológica em que o mesmo e o outro se equivalem.
} 
Espaço de discussão da partilha, a comunidade traz à tona questões de que se acerca com tamanha proficuidade que seria difícil convencer uns tantos céticos de que a questão da comunidade requer a própria escritura para discuti-la e debater-se. No entanto, a quem a ela dedica um pouco dos olhos e a escuta não será tão difícil tarefa persuadir também de que o pensamento estético está repleto de questões que valem por ele inteiro. E repleto não menos de comentaristas e pesquisadores defendendo a sua especialidade como a mais especialíssima das espécies de perguntas que possam ser formuladas. Talvez seja o caso de admitir um "cada vez" para cada e toda questão que se possa pensar como inadmissivelmente impensável e necessariamente pensante de si e de seu espaço de pensamento - o pensamento especulativo, a literatura, estética e ética e política - como inalienável daquilo que propriamente pensa e questiona.

A comunidade é questão de experiência. A experiência é por sua vez senão a questão atrás do sujeito e da comunicação, certamente o fio a que tudo parece encaminhar-se e - se é insustentável a experiência enquanto norte - também é indesejável que tudo seja redutível a uma questão de experiência, mas talvez seja ela o mais pego dos atalhos. É certamente de fundo empírico a possibilidade de um sujeito; e este se fundamenta nela como em uma raiz. A experiência é propriamente apenas experiência de uma consciência ou de algo que proclame-se consciente, seja determinando objetos, seja clamando independência do mundo objetivo para assentar-se sobre ele como num trono.

A experiência é soberana e não é raro que o sujeito seja muitas vezes substituído, em Derrida, por figuras capitais; mesmo que ele se refira ao sujeito, evitado e quase de todo ignorado por essa palavra, Derrida se refere antes à experiência, ao trauma, à justiça, isto é, questões que constituem o sujeito enquanto tal. "O soberano está no comando" é dito por Derrida com a expressão francesa "est à la tête. É possível em francês um jogo com "'État" e "tête" (substituindo o "sujeito" pelos seus deslocamentos) e Derrida toma proveito desse (como diz Blanchot ao início de seu livro) "defeito de linguagem" - a única possibilidade de uma desconstrução, pela différance.

É certamente problemático definir um começo para a desconstrução no corpus do texto ou na textualidade sem correr o risco de cair numa 
programática. Mas é possível dizê-lo do ponto de vista originário da desconstrução, enquanto possibilidade de uma desconstrução. É por isso que se diz em "potências semânticas" e problemas de significação. Há uma proximidade derivada daí entre a desconstrução enquanto prática e o poema ou qualquer prática de sentido que se imponha "problemas de significação".

Se há cabeças, a comunicação parte de uma necessidade de partilha entre elas. A experiência pressupõe a comunicabilidade do experienciável e tem como seu próprio a comunicação da experiência:

[U]m entendimento ou comum acordo, seja o acordo momentâneo de dois entes singulares, quebrando com poucas palavras a impossibilidade de dizer que o traço único da experiência parece conter; seu único consolo: ser intransmissível, que pode ser completado de tal forma: a única coisa que vale a pena é transmitir o intransmissíve ${ }^{30}$.

Quebrar numa conversa ou diálogo entre dois entes singulares "a impossibilidade de dizer que o traço único da experiência parece conter" é já alocar na impossibilidade de dizer a possibilidade mesma do dito. Dizer a experiência parece ser a única forma de experiência mesma ao mesmo que a única coisa que essencialmente e como tal a frustra na frustração que é sua origem e razão de ser.

\section{O objeto do êxtase}

A comunidade é a primeiridade. $O$ indivíduo é pura abstração mental. Isso não é diferente da postura materialista frente ao sujeito ou a ideia de unidade que permeia o indivíduo por detrás. Aí que entende-se o êxtase como regra e contrarregra da comunicação.

"O objeto do êxtase é a negação do ser isolado"131: O assunto do êxtase portanto é o contraexemplo ao ser isolado ou à ideia do indivíduo como para uma matemática rudimentar em que a comunidade é uma soma de unidades

\footnotetext{
${ }^{30}$ Id. Ibid. p. 35

${ }^{31}$ Bataille apud Blanchot: Id. Ibid., p. 36
} 
primárias que ficam à esquerda da equação. $\mathrm{O}$ indivíduo não passa de uma derivação idealista de um entendimento da comunidade. Isso não é dizer que há uma antecedência da sociedade ao indivíduo de direito. Nem é clamar por um retorno a estruturas sociais mais justas e "comunitárias" em que a relação com a "totalidade" não era ainda mediada e mediada e apartada e alienante, já que uma relação-a-si por mais e mais vezes taxada de egocêntrica e narcísica - "males" do nosso século - não é senão a relação com a totalidade a que se quer retornar - numa deturpação de retornos em continuidades - ou ao menos é lícito dizer haver uma troca de lados entre a falência e a integridade para ou a comunidade ou o sujeito, este ou aquele lado.

"Seu aspecto decisivo é que aquele que a experiência não está mais lá quando o experimenta, portanto não está mais lá para experimentar de todo" ${ }^{32}$. A experienciação do êxtase é impossível justamente, para Bataille, porque o êxtase desintegra o indivíduo, racha-o para o ilimitado, portanto desfazendo o indivíduo de sua individualidade cujo traço conformador é o limite. No entanto, se entendido enquanto jouissance egoica e autocomplacente, o êxtase não é experienciável senão pelo outro já que não há ninguém lá para experienciá-lo, pois a marca mesma do êxtase é a abertura ao ilimitado que desfaz o sujeito ou a possibilidade de um sujeito da experiência por negar aquilo que propriamente o rege: seu limite.

[...] "minha conduta com meus amigos tem suas motivações: cada ente, deixado a si mesmo, é, eu acredito, incapaz de ir aos limites do ser," essa afirmação implica que a experiência não poderia acontecer para o ente sozinho [indivíduo] pois sua característica é quebrar a particularidade de uma pessoa particular e expô-la a algo outro ${ }^{33}$.

Se o homem experiente é aquele que resguarda-se de seu conhecimento e vasto saber específico sobre uma área do conhecimento, aquele a quem se assegura assertir sobre o certo e o errado em seu enquadramento epistemológico, é porque a experiência enquanto conceito histórico guarda laços estreitos com a episteme. Uma possibilidade de empiria

\footnotetext{
32 Id. Ibid. p. 37

33 Id. Ibid. p. 40-41
} 
é no fundo uma esperança de saber. Os conceitos de limite e finição estão também no cerne da questão da experiência. O estigma histórico da experiência enquanto conceito analítico é que é preciso uma totalidade determinada para que se dê experiência, para que se possa sabê-la. O êxtase ao mesmo tempo que desfigura a intricada rede entrelaçada pelo pensamento especulativo sobre seu resguardo de possibilidade de saber, também desmorona qualquer interesse que se possa derivar de uma ideia de finição e objeto para uma ideia analítica de experiência. No entanto, esse é um esquema geral panorâmico sobre a ideia de experiência para o pensamento especulativo analítico. Há outras sugestões de experiência pela literatura.

O êxtase quebra a "particularidade de uma pessoa particular" ao impossibilitar a experienciação do que the arrebata cindindo-o, abrindo-o ao outro. O êxtase demonstra a impossibilidade de fundo que possibilita 0 acontecimento de experiência como tal e vê nela funcionamento límpido o que é visto estruturalmente enquanto parasitismo e falha.

[À]s vezes, e ao mesmo tempo, a experiência ("ir ao extremo") pode ser como tal apenas se permanece comunicável, e é comunicável apenas porque, em sua essência, é uma abertura ao fora e uma abertura a outros, um movimento que provoca dissimetria violenta entre eu mesmo e o outro: a fissura e a comunicação ${ }^{34}$.

A particularidade da experiência é uma questão de limite e de "ir ao extremo" (épeiros* ${ }^{*}$ como limite e raiz para a experiência - experienciar em Nancy adquire mais tardiamente o sentido de um "tocar os próprios limites" na impossibilidade mesma dessa imagem que é o que no entanto fundamenta $o$ problema de significação da experiência e do indivíduo naquilo que mais de pronto os possibilitam acontecer e acontecer de novo; é do ponto de vista de um "defeito de linguagem", certo, que Nancy dá conta de uma tactilização da experiência). É uma questão de externalidade no tanto em que é partilhável, comunicável e implica uma saída de uma experiência interna do sujeito para uma experiência do objeto, externo em suas extremidades. No entanto, essa é ${ }^{34}$ Id. Ibid. p. 40 
apenas uma descrição morfológica do suposto funcionamento essencial - que não deixa de deslindar pelo metafórico e figurativo - da comunicação enquanto figura.

Na medida em que o êxtase permite entrever o quanto a questão da experiência tem a ver como uma certa topologia do dentro/fora, na medida em que o êxtase enquanto fenômeno é o deslindar da experiência em sua impossibilidade mesma que a possibilita acontecer, disso resulta um interesse na comunicação como pautada na mesma estruturalidade e enquanto causalidade e motivação da experiência. Forma de comunicação no tanto em que abertura ao outro, a escrita chama a atenção de Bataille pelo desconhecido a que se dirige.

\footnotetext{
"Aquele para quem escrevo" é alguém que não posso conhecer, é alguém que é o desconhecido, e a relação com o desconhecido, mesmo em escritura, expõe-me à morte ou finitude, aquela morte que não tem em si o poder de apaziguar a morte. $\mathrm{O}$ que então cabe à amizade? A amizade: amizade pelo desconhecido sem-amigos. Ou, ademais, se amizade invoca a comunidade pela escrita, ela consegue isso apenas apesar de si mesma (amizade, pela exigência da escritura que exclui toda amizade $)^{35}$.
}

A relação da comunidade com o desconhecido, com a impossibilidade de saber que estrutura todo saber, é visível numa comunidade escritural com o não-saber daquele a quem se escreve; Bataille diz que morreria se soubesse para quem escreve, seu leitor iria desprezá-lo etc. O relacionamento com o desconhecido, até em escritura, expõe-se à morte e à finitude. Isso é, na resposta de Blanchot à problemática sugerida por Nancy, a estruturalidade mesma da comunidade: ela abre/perfaz uma abertura para a morte, a finitude enquanto impossibilidade numa figuração de incompletude; as figuras do abandono. Desde aí, "[...] a anonimidade do livro que não se dirige a ninguém e que, através de sua relação com o desconhecido" ${ }^{36}$ é o que proposita Bataille falar em uma "comunidade negativa: a comunidade daqueles que não têm

\footnotetext{
${ }^{35}$ Id. Ibid. p. 44

${ }^{36}$ Id Ibid p. 45
} 
comunidade" ${ }^{37}$. Partindo de uma anonimidade do leitor, do livro, mesmo e apesar da assinatura do "autor", tem-se a conceptualização derridiana de contra-assinatura, que só pode dar-se numa anonimidade e é anterior a qualquer assinatura, sendo essa não-coincidente com o próprio ato de assinar.

\title{
Comunidades literárias: exposição e partilha
}

É a partir de uma comunidade da escritura que advém uma questão da comunidade.

\begin{abstract}
Veja-se, "a base da comunicação" não é necessariamente a fala, ou mesmo o silêncio que é seu fundamento e pontuação, mas a exposição à morte, não mais minha própria exposição, mas a de alguém outro, cujo viver e presença mais próxima é já ausência eterna e insuportável, uma ausência que o trabalho do mais profundo luto não atenua ${ }^{38}$.
\end{abstract}

O fundamento da comunicação é a exposição à morte, não mais a exposição de um soberano, mas a de outro (nem a de um soberano a um outro, mas a de um outro a um outro). Isso está próximo à rejeição de Nancy de que a comunidade é feita de indivíduos. Nancy está mais inclinado a crer que a comunidade é feita de singularidades, o que é dizer alteridades. $O$ indivíduo é o resultado da dispersão e fracasso da comunidade desde o início.

A comunidade expõe o Eu à solidão, ao abandono infinito. E é por esse gesto que Blanchot, via Bataille, indica o traço próprio da comunicação análogo à abertura à alteridade que é a exterioridade pura no êxtase. Eis aí que a mesma necessidade que fundamenta a conglomeração é a que regra a dispersão. A abertura não é um momento posterior a um fechamento originário, como nos força pensar o aceite da ideia de individualidade como um átomo fechado em si mesmo.

"Inerte, imóvel, menos uma conglomeração que a sempre iminente dispersão de uma presença momentaneamente ocupando todo o espaço": Esse espaço que ocupa é "contudo sem lugar (utopia), um tipo de messianismo anunciando nada senão sua autonomia e inoperância" ${ }^{39}$. Dizer que a iminente dispersão de uma presença é o que junta o

\footnotetext{
${ }^{37}$ Id Ibid p. 45

${ }^{38}$ Id. Ibid. p. 46

39 Id. lbid. p. 57
} 
aglomerado é dizer que o mesmo que dizer que "[a]lguns traços [...] os distinguem enquanto os juntam ${ }^{\prime \prime 40}$ ou que o que originariamente os põe em agrupamento é o mesmo que os faz separarem. Não somente e melhor ainda: o que os une em grupo é a iminência de dispersão. É o que diz Blanchot de várias maneiras uma vez e outra, "a estranheza daquela sociedade ou associação antissocial, sempre pronta para dissolver-se, formada de amigos e pares $^{\text {"11. }}$.

40 Id Ibid p. 57

${ }^{41}$ Id Ibid p. 57 


\section{CAPÍTULO ॥ \\ Mais de um, Nancy e Bataille}




\section{A comunidade do mais de um}

O que regra, e sob que necessidade isso é feito, a associação ou sociedade (sempre pronta à dissolução) formada por amigos ou casais. Eis aí um traço da comunidade. Eis aí também o que justifica Blanchot reservar uma grande parte de seu livro à questão dos "pares". Ele trata sobre Tristão e Isolda e La maladie de la mort de Marguerite Duras. Ambos permitem ver a questão da comunidade, do comum da associação amorosa. Uma questão que é fundamental quer se queira saber aquilo que pode unir ou associar e separar no tanto em que é uma das respostas à pergunta do que justifica tal estruturalidade de um fracasso antes do começo.

La maladie de la mort de Marguerite Duras serve a Blanchot como enigma cuja pergunta, senão primordial, uma das várias possíveis perguntas que se segue da leitura é a possibilidade de comunidade, ou comunidade verdadeira numa sociedade mercantilista em que as associações ou sociedades interpessoais, sejam vistas a nível de amizade ou pareamento, é sempre mediada por uma mercantilização da associação. Essa leitura ou entendimento de leitura de La maladie de la mort de Duras é como que sugerida por Blanchot como redutora. O texto é irredutível, aí reside seu mistério e interesse além de sua brevidade, diz Blanchot.

\footnotetext{
Disso pode-se concluir que o absoluto da relação foi pervertido desde o começo e que, numa sociedade mercantil, há de fato comércio entre entes mas nunca uma verdadeira "comunidade", nunca um conhecimento que é mais que uma troca de procedimentos bons, ou "bens", sejam eles extremos quão concebível possa $\operatorname{ser}^{42}$.
}

$O$ trecho de que Blanchot conclui que "o absoluto da relação foi pervertido desde o começo" e que "nunca [há] uma verdadeira comunidade" é o trecho final do récit de Marguerite Duras: "Logo desistes, não a procura mais, nem na cidade ou à noite ou de dia: mesmo que tenhas conseguido viver aquele amor no único jeito possível para você. Perdendo-o antes que

${ }^{42}$ Id. Ibld. p. $60-61$ 
começasse" ${ }^{43}$. O relato impossível de Duras se dá numa cama próxima de uma varanda que dá vista ao mar. Os lençóis da cama sempre desalinhados lembra Marguerite ao final da obra que, orientando uma possível adaptação teatral, devem fazer referência às ondas do mar e à quebração. A mulher desejada pelo homem inexplicavelmente sempre dorme. Ela está ali como que um objeto a seu pensamento e resistente a qualquer coisa que se possa pensar dela. Há como que um contrato entre eles e que não fica claro de que natureza propriamente. Todo o relato se dá em um endereçamento a um Tu masculino. Todas as cenas se passam no escuro e os corpos são silhuetas. Da conclusão do récit de Marguerite Duras, Blanchot afirma que:

[É] uma conclusão que em sua admirável densidade pode afirmar, não o fracasso de um amor em um caso particular, mas a consumação de todo amor verdadeiro que consistiria em realizar-se exclusivamente de acordo com a maneira da perda, o que é dizer realizando-se ao perder não o que nunca te pertenceu mas o que alguém nunca teve, pois o Eu e o outro não vivem no mesmo tempo, nunca estão juntos (sincronicamente), não podem portanto ser contemporâneos, mas separados (mesmo quando unidos) por um "não ainda" que vai mão em mão com um "não mais" $"$.

O paralelo com o amor deve ser evitado de ser lido como um desvio da questão da comunidade. Ele é um paralelo analógico e a um só tempo "estrutural" com a comunidade. Os amantes "separados (mesmo quando unidos)" têm o interesse de serem o par mínimo da associação. A comunidade mais irredutível é o "mais de um". A necessidade de pensar a perda não como fracasso mas como maneira de realização exclusiva do amor é comparável com a "análise" de Derrida dos atos performativos de Austin. Em Signature, événement, contexte, Derrida vê uma resistência de Austin de considerar os "performativos estéticos" como parte da estrutura. Austin os propõe como parasitários, fracassos de uma ordem e sistema perpetrados pelo performativo. Para Derrida no entanto a possibilidade de fracasso do performativo não é a contrarregra do sucesso, mas a possibilidade de incerteza que assombra e estrutura o sucesso de performance de linguagem.

${ }^{43}$ Duras apud Blanchot: Id. Ibid., p. 61
${ }^{44}$ Id. Ibid. p. 61 
É comum ver em vários textos de Derrida uma mesma "lógica de análise": a possibilidade de insucesso ou fracasso é o que estrutura a possibilidade de sucesso ou integridade sistemática. É da essência de um sistema opor-lhe o insucesso como tragédia ou insucesso. É do funcionamento da lógica metafísica engendrar oposições termo a termo. É da natureza da ciência a lógica metafísica que a estrutura e a faz assentar em toda a história da filosofia ou pensamento ocidental. Derrida entende a "sistematicidade" do sistema não pela oposição de um frente a frente entre exterioridades, oposições de entidades fechadas em si. Ele entende as "oposições termo a termo" como um dentro da sistematicidade dos pares, repetições do mesmo. Portanto, se sucesso opõe-se a insucesso, Derrida faz o insucesso não mais valer como a exterioridade absoluta de sucesso mas propõe que o fracasso é a possibilidade de "mal" que possibilita qualquer "bem"-sucedido produto. Nisso, ambos são parte da impossibilidade de sucesso pois que se ambos são possíveis, a potência de insucesso é logicamente tanto igual à de sucesso ambos estão na noite do saber cuja escuridão repleta deixa tudo ao mesmo nível de possibilidade de atualização, o que é tanto a completa potência de tudo acontecer quanto o Nada que jamais acontecerá senão enquanto promessa.

Colocá-los em termos lógicos como "possibilidade" e "impossibilidade" é fazê-los remeter a uma outra oposição que Derrida apaga: contiguidade e necessidade são de tal forma contrários que podem ser ditos um pelo outro como possibilidade de mais de uma possibilidade e impossibilidade de possibilidades outras. Ou mesmo: impossibilidade de necessidade e impossibilidade de contiguidade. A necessidade é historicamente a comunhão da possibilidade consigo mesma pois que é a única possibilidade de fato, não há qualquer outra possibilidade de facticidade em vista. E a possibilidade de possibilidades é então a partilha?

\section{Figuras literárias da comunidade - Tristão e Isolda e La maladie de la mort}


Tristão e Isolda representa para Blanchot o paradigma de amor partilhado.

O paradigma de amor partilhado [...] exclui a simples mutualidade assim como a unidade em que o Outro se imiscuiria com o Mesmo. $E$ isso nos traz à premissa de que o amor elude a possibilidade, eludindo, aqueles pegos por ela, seus poderes, suas decisões e mesmo seus "desejos", no que é a estranheza mesmo, tendo consideração nem pelo que podem fazer nem pelo que não querem, mas atraindo-os numa estranheza em que tornam-se exilados de si mesmos, a uma intimidade que também os exila um do outro ${ }^{45}$.

"A comunidade entre esses dois entes, que nunca toma lugar num nível psicológico ou sociológico, é a mais surpreendente e no entanto a mais evidente ida além do mítico e do metafísico" ${ }^{46}$ diz Blanchot. $O$ amor partilhado é o paradigma por sua vez da comunidade ao nível mínimo em que duas pessoas partilham suas solidões que só podem expressar-se em companhia.

O exílio de si mesmos e de um do outro pela intimidade ou proximidade é o traço de comunidade que, em grandes números, é o que traz à tona a questão do indivíduo em seu viés social ou de sociabilidade numa discussão acirrada do social não mais enquanto números incontáveis aproximando-se à infinidade da cultura, mas como o interpessoal ou mais de um que demonstra a incrível solidão das massas.

O feminino vem com um excesso, um aparente excesso. É essa a conclusão injustamente apressada de uma análise do récit de Marguerite Duras que se quer atrelar a alguns corolários para uma possível comunidade. Blanchot considera o amor partilhado, simbolizado pelo amor mútuo de Tristão e Isolda, o grão de essência da comunidade ao nível mais irredutível do mais de um, pelo menos é o que precisa estar pressuposto para que se negue de Tristão e Isolda qualquer mutualidade.

Deve-se ultrapassar a "simples mutualidade assim como a unidade em que o Outro se imiscuiria com o Mesmo", pois o amor elude a possibilidade. Que é que se quer dizer com isso? Seria por causa do traço efetivamente necessário e forçosamente efetivo com que instaura o amor seus laços pelos

\footnotetext{
${ }^{45}$ Id. Ibid. p. 72

${ }^{46}$ Id Ibid p. 86
} 
indivíduos? Ou o traço efetivo e necessário de qualquer coisa que efetivamente seja, seja qualquer uma essa coisa, não eludiu ela toda outra possibilidade agora morta para que apenas ela necessária e efetivamente se desse?

Mesmo antes de seu começo a comunidade já se perde. Há um paralelo claro com uma comunidade em seu nível irredutível, e portanto essencial, e o laço amoroso entre dois. Tristão e Isolda é uma narrativa de reconhecimentos: há um jogo entre o que está à luz, é sabido por todos, alguns ou segredado entre dois e o que está às sombras, segredado de todos, não sabido ou iminente a vir às claras.

Rei Marcos, tio de Tristão, forçado a escolher entre um golpe de seus vassalos ou o casamento para que o trono não fosse herdado por Tristão, de quem não gostavam, pensava como sair de tal situação quando, esperando enganar seus invejosos vassalos, decreta que casaria com quem quer que fosse a dona dos fios dourados que umas andorinhas trouxeram ao parapeito da antecâmara real. Nenhum dos presentes duvidou que se tratasse de uma nobre. Tristão, honra primeiro, disponibiliza seu corpo e sua coragem à tarefa.

Daí o excesso do feminino (expresso em nome masculino), desde que suas incontáveis possibilidades ultrapassam de muito a concretude de uma necessidade que o estancasse em real e fático. É isso uma pergunta? Mas como entender o feminino como traço extático de uma comunidade (nenhuma essência é fluida) apesar de seu excesso sem ponto de basta? Está claro que nenhuma afirmação como tal é feita. As perguntas são possíveis, apesar de não feitas em Blanchot.

No entanto, há algo como um excesso e uma ausência ou falta de estancamento na comunidade inconfessável. "E é esse exatamente um dos traços da comunidade, quando ela se dissolve, dá impressão de nunca ter podido existir, mesmo quando de fato existiu"47: Nunca ter podido existir, isto é, jamais ter estado numa certa ordem de atualidade mesmo quando existiu faticamente. Não há aí algo de um fluxo impedindo necessárias atualizações daquilo que é de modo estanque?

47 Id Ibid p. 88 
A leitura do relato ficcional de Marguerite Duras deixa ver que o feminino é um excesso. Com Bataille veremos diferentemente.

\section{Entre abismo, mesmo e outro: erotismo de Bataille}

\section{Descontinuidade e reprodução}

Em O erotismo de Bataille: "[...] o erotismo é a aprovação da vida até na morte" ${ }^{48}$. É certo também que há entre os seres, para Bataille, uma descontinuidade. Algo que pretende em potência uma convergência final ou uma união. Se Bataille opõe dois polos do espírito humano, a santidade e a sensualidade, ele também as une numa mesma medida desde que sua separação impõe-lhes uma necessidade de resolvimento do paradoxo originário que permite que se oponham e ainda sejam da mesma natureza aplicada ao espírito enquanto objeto.

Entre um ser e outro há um abismo, uma descontinuidade. Esse abismo situa-se, por exemplo, entre vocês que me escutam e eu que Ihes falo. Tentamos nos comunicar, mas nenhuma comunicação entre nós poderá suprimir uma primeira diferença. Se vocês morrerem, não sou eu que morro. Nós somos, vocês e eu, seres descontínuos ${ }^{49}$.

Apesar da tentativa de comunicação, que reserva etimologicamente e talvez até originariamente uma semelhança linguística que aponta para uma parecença ontológica com a união de uma comunhão, não há como, pela união, aceite-se, "suprimir uma primeira diferença". Essa diferença é apenas demonstrada pela morte que aniquila uma das partes de uma comunidade. "Se vocês morrerem, não sou eu que morro", é dito de maneira de exemplo. E, conclusivamente, "[n]ós somos, vocês e eu [note-se a resistência de um "nós" sem uma quebra em suas partes], seres descontínuos". A descontinuidade entre os seres é vista através da morte. Eis aí a resistência à comunidade, vista aí pela imagem de uma comunicação hipotética e fática. É ainda essa diferença

\footnotetext{
${ }^{48} 2012$, p. 10

${ }^{49}$ Bataille, 2012, p. 10.
} 
uma "primeira diferença". Algo como um traço único originário que jamais poderá ser suprimido por uma ideia de comunidade como o é a prática de uma comunicação.

O espermatozoide e o óvulo estão no estado elementar dos seres descontínuos, mas se unem e, em consequência disso, uma continuidade se estabelece entre eles para formar um novo ser, a partir da morte, do desaparecimento dos seres separados. O novo ser é, ele mesmo, descontínuo, mas traz em si a passagem à continuidade, a fusão, mortal para cada um deles, dos dois seres distintos ${ }^{50}$.

Há na ideia de descontinuidade da reprodução sexual uma diferença originária. A morte que se lhe opõe é uma continuidade e uma identidade. Uma tal diferença entre seres que é também sua descontinuidade torna-se pela morte ou desaparecimento da descontinuidade uma continuidade mortal que é o resultado da reprodução. A "passagem à continuidade, a fusão" é também uma continuidade de linhagem e permanência ao mesmo que é a fusão de dois que se torna um:

Em nossa origem, há passagens do contínuo ao descontínuo ou do descontínuo ao contínuo. Somos seres descontínuos, indivíduos que morrem isoladamente numa aventura ininteligível, mas temos a nostalgia da continuidade perdida. Não aceitamos muito bem a ideia que nos relaciona a uma dualidade de acaso, à individualidade perecível que somos ${ }^{51}$.

A descontinuidade dos seres é vista pela facticidade de "indivíduos que morrem isoladamente" e a "nostalgia da continuidade perdida" é partilhada originária e comunitariamente, como expresso em um "nós temos". No entanto e ainda, a individualidade é também partilhada, talvez somente nostalgicamente e enquanto ideia de uma "individualidade perecível que somos". O "somos" é a justa medida de uma partilha entre "nós" que resiste à continuidade pela expressão em individualidade dos seres descontínuos.

\footnotetext{
${ }^{50}$ Id. Ibid. p. 12

${ }^{51}$ p. 12
} 
Esses indivíduos que morrem isoladamente, podem eles ser os corpos individuados que negam pela suficiência de membros a partilha que eideticamente pressupõe insuficiência? Para Blanchot há na origem dos seres uma insuficiência dos indivíduos que não é superada na comunidade, pelo contrário, vê-se a insuficiência pela morte que se dá apenas comunitariamente. Para Bataille, uma descontinuidade entre os seres poderá ser entendida enquanto individuação corpórea?

É aí que entram as três formas do erotismo, que obviamente implicam em três formas de descontinuidade descontínuas:

Falarei sucessivamente dessas três formas, a saber: o erotismo dos corpos, o erotismo dos corações e, finalmente, o erotismo sagrado. Falarei dessas formas a fim de deixar bem claro que nelas o que está sempre em questão é substituir o isolamento do ser, a sua descontinuidade, por um sentimento de continuidade profunda ${ }^{52}$.

O que está sempre em questão em cada uma das formas do erotismo é "substituir o isolamento do ser, a sua descontinuidade" por uma "continuidade profunda"; logo, temos também três formas de descontinuidade ou três níveis de expressão distintos de uma mesma diferença de base: os corpos, os corações e o sagrado.

Essencialmente, o domínio do erotismo é o domínio da violência, o domínio da violação. Mas reflitamos sobre as passagens da descontinuidade à continuidade dos seres ínfimos. Se nos referimos à significação desses estados para nós, compreendemos que a separação do ser da descontinuidade é sempre a mais violenta. O mais violento para nós é a morte que, precisamente, nos arranca da obstinação que temos de ver durar o ser descontínuo que nós somos. Desanimamos face à ideia de que a individualidade descontínua que está em nós de repente vai acabar ${ }^{53}$.

52 Id. Ibid. p. 13

53 Id. Ibid. p. 13 
Eis aí que o término da "individualidade descontínua" propõe uma passagem da descontinuidade à continuidade e que o erotismo é essa separação essencialmente violenta. O erotismo implica numa separação da obstinada permanência à descontinuidade e uma passagem desta à continuidade que tem na morte sua figura última. Figura ou facticidade. Essa passagem é um movimento de dissolução que é o momento mesmo do erotismo que empreende o ato sexual.

"No movimento de dissolução dos seres, a parte masculina tem, em princípio, um papel ativo, enquanto a parte feminina é passiva"54. Uma erótica empreendida em papéis sexuais ativos e passivos relacionados ao masculino e feminino só tem sentido num sistema em que o erotismo é indissociável da reprodução sexual. Visto que Bataille admite que o ato sexual e a reprodução dos seres é parte constitutiva do erotismo, tem-se que a "originariedade" desta diferença é possivelmente resumida à diferença sexual. O erotismo em Bataille é o apesar da reprodução.

A atividade sexual de reprodução é comum aos animais sexuados e aos homens, mas, aparentemente, só os homens fizeram de sua atividade sexual uma atividade erótica, e o que diferencia o erotismo da atividade sexual simples é uma procura psicológica independente do fim natural encontrado na reprodução e na preocupação das crianças ${ }^{55}$.

O erotismo é a jouissance de "uma procura psicológica independente do fim natural encontrado na reprodução" ou a possibilidade de entretenimento enquanto manutenção do gozo apesar da reprodução. Admitiria Bataille essa palavra? Entretenimento aqui entendido certamente como divertimento e manutenção psicológica de estados estéticos que produzem e admitem significação para além da reprodução. Não é justamente a relação de uma dualidade na descontinuidade a papeis sexuais passivo e ativo e uma consequente diferença sexual entre masculino e feminino que os empreende e os empenha naturalmente o que torna indissociáveis o erotismo e a reprodução?

\footnotetext{
54 Id lbid p. 14

55 Id Ibid. p. 10
} 


\section{A parte feminina do erotismo}

Onde está o apesar da independência do erotismo de uma reprodução sexual? Em que se assenta finalmente a originária diferença entre humanos e animais senão na incapacidade destes de livrar-se de uma lógica naturalista de reprodução se aqueles humanos, homens e mulheres, empenham papéis sexuais naturais mas podem perpetrar procuras psicológicas independentes da finalidade também natural do ato sexual?

É essencialmente a parte passiva, feminina, que é dissolvida
enquanto ser constituído. Mas para um parceiro masculino a
dissolução da parte passiva só tem um sentido: ela prepara
uma fusão onde se misturam dois seres que ao final chegam
juntos ao mesmo ponto de dissolução. Toda a concretização
erótica tem por princípio uma destruição da estrutura do ser
fechado que é, no estado normal, um parceiro do jogo ${ }^{56}$.

Desde aí que o erotismo é uma jouissance que independe da finalidade natural do ato reprodutivo, pois se empregam dois parceiros num jogo que pretende "uma destruição da estrutura do ser fechado que é, no estado normal, um parceiro do jogo". O termo empregado "jogo" revela a independência da finalidade reprodutiva, pois todo jogo independe de finalidade senão ele mesmo. No entanto, há ainda um "estado normal" e apenas nele é que se tem parceiros de um jogo. Ao mesmo tempo, o erotismo enquanto jogo é um estado extraordinário desde que pretende uma destruição da estrutura do parceiro do jogo, em estado normal, o ser fechado. Nessa fusão que é destruição violenta do ser fechado, há uma norma ou normatividade sem a qual não há jogo visto que não há jogo sem normas.

A "parte passiva, feminina" é que é "dissolvida enquanto ser constituído" e portanto é primeiramente o feminino que é o ser fechado. A dissolução da parte passiva só tem um sentido para um parceiro masculino: prepara uma fusão em que se misturam dois seres e que chegam a uma dissolução final que é o mesmo ponto, talvez coincidente com o gozo sexual, fim da jouissance. No entanto, pode-se dizer que a dissolução da parte passiva e feminina só tem sentido para o parceiro masculino e que esse sentido é apenas um: o

${ }^{56}$ Id. Ibid. p. 14 
apagamento total da diferença em uma fusão que mistura dois em um mesmo ponto. Em que reside o sentido para o feminino? O observador do sentido é necessariamente masculino. A residência do sentido é feminina sem contudo saber jamais do sentido que tem, sendo ele apenas para o outro, o homem, que coincide em seu estado natural de observador passivo do sentido além de si e seu papel sexual ativo e destruidor.

\begin{abstract}
A ação decisiva é o desnudamento. A nudez se opõe ao estado fechado, isto é, ao estado de existência descontínua. É um estado de comunicação que revela a busca de uma continuidade possível do ser para além do voltar-se sobre si mesmo. Os corpos se abrem para a continuidade através desses canais secretos que nos dão o sentimento da obscenidade ${ }^{57}$.
\end{abstract}

O desnudamento do corpo feminino pelo homem (não há como entender de outro jeito) é a destruição do estado natural e fechado do ser descontínuo feminino. Há presente uma comunicação reveladora de uma "continuidade possível" entre os corpos apesar de uma diferença sexual que às vezes (certamente nesse caso) coincide com uma diferença de papéis sexuais, ativo e passivo. Os corpos, no entanto, se abrem para uma continuidade apenas e somente por causa e através de suas diferenças genitais, seus "canais secretos". Essa continuidade é alcançada em uma fusão final através da penetração (não há como relevar de uma fisiologia e morfologia sexuais apesar de Bataille admitir um "em princípio" para o papel ativo do homem, não se vê um seguimento a um "em princípio" transitório no tanto em que é relegada à parte feminina uma passividade "essencialmente" dissolvida enquanto ser constituído; já que está peremptoriamente a ela reservada a desconstituição, o homem, ativo, permanece constituído e estável).

O erotismo dos corpos tem de qualquer maneira algo de pesado, de sinistro. Ele guarda a descontinuidade individual, e isto é sempre um pouco no sentido de um egoísmo cínico. O erotismo dos corações é mais livre. Ele se separa, na aparência, da materialidade do erotismo dos corpos, mas dele

${ }^{57}$ Id. Ibid. p. 14 
procede, não passando, com frequência, de um seu aspecto estabilizado pela afeição recíproca dos amantes. Ele pode se desligar inteiramente daquele, mas isto são exceções, justificadas pela grande diversidade dos seres humanos. Em sua origem, a paixão dos amantes prolonga no campo da simpatia moral a fusão dos corpos entre $\mathrm{si}^{58}$.

O erotismo dos corpos difere daquele dos corações. Este é mais livre. Aquele guarda um egotismo da descontinuidade individual que é a força mesma que constitui os indivíduos enquanto corpos. A liberdade do erotismo dos corações está em que ele aparentemente "se separa [...] da materialidade do erotismo dos corpos, mas dele procede, não passando [...] de um seu aspecto estabilizado pela afeição recíproca dos amantes" (p. 15). Está dito que o que difere o erotismo dos corpos do erotismo cordial é uma certa afeição recíproca, o que resulta em um erotismo estabilizado. Em Bataille os corpos desejam e os corações apaixonam-se sob a violência, mais violenta que o desejo, da paixão que é confusão e desordem.

O peso e o quê de sinistro do erotismo dos corpos (daqui pra frente desejo) não é contraposto a uma leveza do erotismo dos corações (daqui pra frente paixão recíproca) senão a uma competitiva comparação de suas violências que é, na paixão recíproca, equiparada ao sofrimento e à morte. $O$ mesmo se dá em Tristão e Isolda, signos do amor mútuo. Beber do cálice uma poção do amor é entregar-se braços abertos para a morte. Em que a reciprocidade exerce a força sinistra da morte se é ela a diferença da paixão ao desejo dos corpos?

Ao amante parece que só o ser amado - isto tem por causa correspondências difíceis de definir, acrescentando à possibilidade de união sensual a união dos corações - pode neste mundo realizar o que nossos limites não permitem, a plena fusão de dois seres, a continuidade de dois seres descontínuos. A paixão nos engaja assim no sofrimento, uma vez que ela é no fundo a procura de um impossível e, superficialmente, sempre a busca de um acordo dependente de condições aleatórias. Entretanto, ela promete ao sofrimento fundamental uma saída ${ }^{59}$.

\footnotetext{
${ }^{58}$ Id. Ibid. p. 15

${ }^{59}$ Id Ibid p. 15
} 
Aparentemente a paixão recíproca é a promessa de uma saída do sofrimento que ela mesma engendra. $O$ desejo dos corpos que antes legava ao homem e mulher posições sexuais, que são antes papeis sócio-sexuais, estanques em atividade e passividade, na paixão recíproca, um outro estado dos mesmos corpos, ganha um certo apagamento de atividade para receber uma passividade completa ou um engajamento que é também uma "procura de um impossível"; assim como todo erotismo é "procura psicológica independente" de uma finalidade natural (que não releva no entanto da naturalidade e normatividade de uma certa política posicional de corpos e de uma escolha pautada na naturalidade reprodutiva desses corpos apesar da dita "independência"). O erotismo cordial acrescentado ao erotismo dos corpos permite uma "plena fusão de dois seres" em continuidade.

O que caracteriza a paixão é um halo de morte. Abaixo dessa violência - à qual responde o sentimento de contínua violação da individualidade descontínua - começa o campo do hábito e do egoísmo a dois, o que quer dizer uma nova forma de descontinuidade ${ }^{60}$.

A morte é o que pauta o erotismo em passagem de descontinuidade a uma continuidade presumida enquanto ideia. A morte é ou a continuidade mesma ou uma expressão da descontinuidade entre os seres em seus estados normais. Bataille organiza numa certa formalidade hierárquica a paixão e o "egoísmo a dois" do erotismo além da lógica reprodutiva, o que compreende o sexo ou ato sexual, aquela seria mais violenta e este último, uma "nova forma de descontinuidade" mais abaixo da "contínua violação da individualidade descontínua".

Por isso, de uma certa maneira, o erotismo dos corações, a paixão, compreende o erotismo dos corpos, o "egoísmo a dois" e o abarca de forma a abri-lo de seu fechamento à agonia e ao sofrimento da perda, violação e violência do erotismo cordial.

${ }^{60}$ Id Ibid p. 18 
É somente na violação - com estatuto de morte - do isolamento individual que aparece essa imagem do ser amado que tem para o amante o sentido de tudo o que é. O ser amado para o amante é a transparência do mundo ${ }^{61}$.

Aqui se vê a real importância da violação da paixão, que viola também o desejo e o desapropria de seu erotismo-egotismo. Até um certo ponto, o ato sexual é ainda a manutenção das individualidades pois "depende" dos corpos e de seus limites. Não há prazer sem uma manutenção dos limites. É justamente esse o estatuto da paixão: deslindar os corpos; quebrar o "isolamento individual" dos corpos, violá-lo, pela imagem da morte ou como a morte mesma.

\section{Parte feminina, receptáculo de sentido}

O "ser amado [...] tem para o amante o sentido de tudo o que é"; sua importância e aparição, aparição do sentido, como talvez toda aparição, só se dá na violação e morte. As posições sintáticas passiva, "ser amado", e ativa, "amante", tem correlatos com as contrapartes feminina e masculina, respectivamente, do ato sexual. Ressalte-se que o sentido da força "desestruturante do ser fechado" reside no feminino enquanto para o masculino; o ser fechado é o excesso feminino. Há um outro correlato de aparição ou comparecimento do mundo ao sentido para o homem. A transparência de mundo é o aparecimento de mundo pelo apagamento ou destruição da individualidade, ego ou fechamento da parte passiva.

"A poesia conduz ao mesmo ponto como cada forma do erotismo; conduz à indistinção, à fusão dos objetos distintos" ${ }^{\prime 62}$. O mesmo ponto a que chegam a parte ativa e passiva do para além da reprodução, em uma procura psicológica independente da lógica reprodutiva, o enjeu dos amantes, é o paralelo poético que equaliza gozo e efeito estético. A fusão dos objetos distintos cria indistinção e portanto apagamento das partes. No entanto, o apagado, a apagada, melhor, é o feminino, a parte passiva é apagada não somente depois da transmutação em continuidade dos corpos, mas desde o

\footnotetext{
${ }^{61}$ Id Ibid p. 18

${ }^{62}$ Id Ibid p. 18
} 
"estado normal" não-sexual, a violência apenas assimila seu apagamento em uma nova identidade perpetrada de continuidade pura.

Se tratarmos da poesia em respeito à obra de Bataille, é somente em uma relação de equivalência que a poesia faz remetimento a sua obra, e em relação ao erotismo em cada uma de suas formas.

A poesia "nos conduz à eternidade, à morte, e pela morte, à continuidade: a poesia é l'éternité. C'est la mer allée avec le soleil ${ }^{63}$.

O apagamento da descontinuidade que conduz à continuidade é também o esquecimento ou ostracização da reciprocidade que diferenciava a paixão do desejo. Não há reciprocidade em o "ser amado" ser o sentido para um ser amante, essencialmente masculino pois é o ponto de vista, o observador, o que detém fala e direito de voz como no récit de Marguerite Duras em que o sentido ou sua ausência é o corpo feminino deitado longe da luz e quem fala e a quem se fala é o homem ou a parte ativa do ato sexual ou passional. A reciprocidade é desde o início o apagamento da diferença e constituição da identidade enquanto prolongamento da continuidade masculina e violação do feminino.

O processo de construção de sentido - não passa disso, o erotismo enquanto trabalho - é sempre a redução do outro ao mesmo. Quando se fala em corpos, o mesmo é o homem, a humanidade mesma em sua construção do sentido histórico. Já a paixão, ou erotismo dos corações, é o mais claro trabalho possível, em seu sentido de processo metafísico de apagamento e aparição de sentido pelo enxerto de presença depois de um momento de suspensão e ausência.

De fato não é negado que o homem é o portador do erotismo. Ele é ativo e agente antes, depois e durante o sexo. O erotismo é "uma desordem elementar, de uma coisa cuja essência é uma mudança que inquieta" (p. 11). Todo $o$ argumento do erotismo se baseia no erotismo enquanto desestruturação, mudança, quebra, e principalmente violação pela violência, de um "estado normal" que é pautado pela limitação, individualidade dos corpos e egos. Em que há então violação se o erotismo não faz nada senão perpetuar o

63 Id Ibid p. 18 
"estado normal", o apagamento da mulher entendido enquanto abertura à masculinidade? O que ele viola se a violação resulta no mesmo que o "estado normal" dos corpos, passivação do passivo?

O erotismo é um dos aspectos da vida interior do homem. Nisso nos enganamos porque ele procura constantemente fora um objeto de desejo. Mas este objeto responde à interioridade do desejo ${ }^{64}$.

O homem. Um dos aspectos de sua vida interior, que no entanto, é uma procura psicológica exterior por um "objeto" que é a exterioridade mesma, todo objeto é passivo, este é também feminino, e que responde à interioridade do desejo masculino, este que procura, perpetra seu objeto numa violência que a transforma de exterioridade pura a interioridade abjeta, e sujeita ao agente do desejo.

A escolha de um objeto depende sempre dos gostos pessoais do indivíduo: mesmo se ela recai sobre a mulher que a maioria teria escolhido, o que entra em jogo é frequentemente um aspecto indizível, não uma qualidade objetiva dessa mulher, que talvez não tivesse, se ela não nos tocasse o ser interior, nada que nos forçasse a escolhe-la ${ }^{65}$.

A escolha, mesmo se forçada, depende o indivíduo, do homem que age em busca e à procura de qualidades "indizíveis", não qualidades objetivas "dessa mulher". Apagamento do corpo, primeiro objeto e depois suspensão da objetividade.

O erotismo do homem difere da sexualidade animal justamente no ponto em que ele põe a vida interior em questão. O erotismo é na consciência do homem aquilo que põe nele o ser em questão. A própria sexualidade animal introduz um desequilíbrio e este desequilíbrio ameaça a vida, mas o animal não o sabe. Nele nada se abre que se assemelhe com uma questão ${ }^{66}$.

O "erotismo do homem" que antes era oposto ao objeto de seu desejo,

\footnotetext{
${ }^{64}$ Id. Ibid. p. 20

${ }^{65}$ Id Ibid p. 20

${ }^{66}$ Id Ibid p. 20
} 
uma mulher de qualidades indizíveis, e portanto sem erotismo que se diga dela, é agora oposto à sexualidade animal. É negado psicologia à mulher e às bestas? Mas "o animal não o sabe". Como a psique extensa de Freud a Nancy, apenas sabem dela, nada ela sabe de si e o que dela sabem os que a rodeiam. Também, como a parte passiva, está e é desnudada. Há aqui também alguns tons heideggerianos. "O erotismo é [...] aquilo que põe nele o ser em questão" que é entendida, a questão, como abertura ao ser, o contrário do "ser fechado" em seu estado natural e naturalista.

\section{Erotismo como redução do outro ao Mesmo}

No entanto, se o ser fechado é a mulher, é "essencialmente a parte passiva, feminina, que é dissolvida enquanto ser constituído"; o erotismo ou concretização erótica, é verdade que "tem por princípio uma destruição da estrutura do ser fechado que é, no estado normal, um parceiro do jogo". Ora, se é a mulher, parte passiva, que é essencialmente dissolvida enquanto ser constituído na concretização erótica que pretende destruir a estrutura do ser fechado, o indivíduo descontínuo, é na mulher que ocorre a abertura que prepara para uma fusão, a destituição ou dissolução do ser feminino; no entanto, "para um parceiro masculino a dissolução da parte passiva só tem um sentido", e já vimos como isso na verdade é dizer, já que as qualidades femininas são indizíveis - elas também não dizem elas mesmas? - que o erotismo só tem sentido para o homem.

Essa dissolução da parte passiva que "prepara uma fusão onde se misturam dois seres que ao final chegam juntos ao mesmo ponto de dissolução", não acaba por fusionar o homem com ele mesmo dado que a mulher, parte passiva, está desconstituída para experienciar qualquer coisa que seja, mesmo uma fusão? O homem, todavia, permanece sujeito.

De súbito, Bataille toma a si seu erotismo, seu próprio erotismo como algo que o pertence propriamente e de que fala em "seu" livro, que só ele pode dizer seu erotismo, é já pautado. Mas não há resquícios de algum erotismo geral? Um traço único do erotismo que "transcenda" indivíduos? 
O erotismo, eu o disse, é aos meus olhos o desequilíbrio em que o próprio ser se põe conscientemente em questão. Em certo sentido, o ser se perde objetivamente, mas nesse momento o indivíduo identifica-se com o objeto que se perde. Se for preciso, posso dizer que, no erotismo, EU me perco. Não é, sem dúvida, uma situação privilegiada. Mas a perda voluntária implicada no erotismo é flagrante ${ }^{67}$.

Sem dúvida não é uma questão de privilégios. É uma questão, que se põe "conscientemente em questão", de por o próprio ser "objetivamente" em questão. O homem que põe-se em questão. Veremos em Jean-Luc Nancy que, também para ele, trata-se de o homem colocar-se questões.

\section{As comunidades de Nancy: sessão de abertura}

\section{Comunidade dos espaços: axiologia}

La communauté desoeuvrée, de Nancy, trata das mesmas questões. Se em Bataille vimos a comunidade irredutível em seu estado mais de um, figurado pelo casal, justificado o paralelo com Tristão e Isolda em Blanchot, em Nancy, volta-se o probelma a uma legibilidade da comunidade em seus aspectos gerais e retoma-se a questão, já apontada por Blanchot e Bataille, da poesia enquanto lugar em que se dá essa comunhão, fusão igual à do erotismo.

Nancy abre seu livro La communauté desoeuvrée, uma resposta que começa o diálogo, de todo modo ela e qualquer outra resposta vem antes da pergunta, ao dizer que vai tratar do "testemunho mais importante e mais penoso do mundo moderno, aquele que une talvez todos os outros testemunhos que essa época se encontra encarrega de assumir" ${ }^{\prime \prime 8}$; talvez dois testemunhos: "nós testemunhamos também o esgotamento do pensamento da

\footnotetext{
${ }^{67}$ Id lbid p. 21

681991 p. 1
} 
História". Mas de todo modo, é do "testemunho da dissolução, do deslocamento ou da conflagração da comunidade" ${ }^{\prime 69}$ de que trata o texto.

Os deslocamentos sociais, tecnopolíticos, culturais, compreendendo estéticos, psicológicos, cognitivos, e por fim, teóricos já ao nível da textualidade, perpassam a abrangência da palavra numa familiaridade herdada do tronco aos galhos etimológicos, lexicais, especializados dos aspectos semânticos da palavra. É aí que se vê a especialidade linguística ou de linguagem que toma o problema da comunidade. Nancy, por exemplo, tem como capítulo de abertura de seu La communauté desavouée, livro que abordaremos mais à frente, um texto que trata da comunidade e o nome.

[A] palavra "comunismo" serve como emblema do desejo de descobrir ou redescobrir um lugar de comunidade a uma só vez além das divisões sociais e além da subordinação ao domínio tecnopolítico, e por isso além de tal gasto de liberdade, de discurso, ou de simples felicidade que advém sempre que esses ficam subjugados à ordem exclusiva da privatização ${ }^{70}$.

Se tal desejo de descoberta é antes político ou antropológico, é por isso que que é admitida a possibilidade no texto presentemente inclassificável de Nancy de redescobrir um lugar de comunidade. Mas talvez essa tentativa de redescoberta seja um novo descobrimento, deslocado ou, de todo modo, traidor daquele que o precede - não é preciso uma traição para o estabelecimento de uma tradição? Senão traição de algo futuramente enquanto ideia, então daquilo enquanto ideia futura de um passado contínuo, tradicional, herdado.

A felicidade que "advém sempre que esses [gastos] ficam subjugados à ordem exclusiva da privatização" remete à comunidade em seu estado mais amplo e de modo geral não redutível ao casal, ao par. Se a privatização não é referida a uma situação dual, entre dois, é por que ela se refere ao objeto mesmo da política, uma partilha ou distribuição do espaço disponível e a consequente interdição e controle estatal desses espaços, para que, assim,

\footnotetext{
${ }^{69}$ Id lbid. p. 1

${ }^{70}$ Id Ibid p. 1
} 
seja compreensível uma ocupação deles, da parte de quem compete ocupálos.

Uma certa tipologia e valorização dos espaços não prescinde da preocupação objetiva da política: distribuição de poder, sua discussão metafísica, em espaços materiais e sensíveis, as únicas propriedades, ou mesmo qualidades objetais, recebedoras de valor econômico e sociocultural. Se Jacques Rancière já houvera introduzido e já também exaurido de belíssimo modo essa questão em seu Le partage du sensible: Esthetique et politique, é justamente por isso que permanece a discussão de uma tecnopolítica em Nancy como uma redescoberta, admitida senão alternativamente.

Quanto ao comunismo enquanto fracasso:

[Isso] não é apenas porque os Estado que aclamaram por ele [comunismo], apareceram, por algum tempo já, como os agentes de sua traição. O esquema da traição, com o objetivo de preservar uma pureza comunista originária de doutrina ou intenção, tem sido vista como cada vez menos sustentável. Não que o totalitarismo tenha já estado presente, como tal, em Marx: isso seria uma proposição rude, uma que permanece ignorante do protesto exaltado contra a destruição da comunidade que em Marx compara-se à tentativa hegeliana de trazer à tona uma totalidade, e que frustra ou desloca essa tentativa ${ }^{71}$.

A questão de uma sustentabilidade do comunismo enquanto projeto tem a ver com sua difícil atualização e implementação. Tudo tem a ver com um necessário abismo entre ideia e mundo. Talvez o "comunismo", "comunidade" e "comunhão", junto a eles toda a discussão de espaços comuns e exclusivos, sejam a figura mais emblemática dessa separação, que dá a ver, ao nível mundano, diferenças morfológicas, ontológicas e axiológicas, portanto, na separação dos indivíduos. Vai aqui sem muito retoque um paralelo, por alto, com a descontinuidade socioeconômica entre indivíduos de que fala Rancière em La nuit des proletaires. Essa disparidade, ou descontinuidade, reflete-se numa outra relação com o tempo dos indivíduos que vivem de restos da elite, não com a temporalidade, mas com a organização do tempo diário, cotidiano.

${ }^{71}$ Id. Ibid. p. 2 
Em termos, também uma divisão temporal e espacial do trabalho que implica numa disponibilidade de seus corpos e numa regulação outra de sua fisiologia e força de trabalho. Isso se estende à discussão de valor de trabalho já que essa descontinuidade entre indivíduos é de todo uma separação segundo o valor da presença e estar-no-mundo. Nesse sentido, uma tal diferença ontológica é sempre uma descontinuidade de valor.

\section{Comunismo: ideário fracassado da partilha}

Quanto à traição do ideário comunista, está longe de ser uma traição de suas ideias. A implementação do comunismo depende de uma ideia de totalidade perdida. A perda dessa totalidade imaginada, pensada nostalgicamente por algum artifício cognitivo, é de algum modo posta em objetivação quando implementa-se uma nova sociedade, novos termos de vivência entre os viventes. O "assombro" da ideia do comunismo é que historicamente sempre se tornou em totalitarianismo.

Foi a própria base do ideal comunista que acabou-se por aparecer mais problemática: nomeadamente, seres humanos definidos como produtores (pode-se até adicionar a isso: seres humanos definidos de qualquer modo), e fundamentalmente enquanto produtores de sua própria essência na forma de seu trabalho ou sua obra ${ }^{72}$.

Definir seres humanos "de qualquer modo" é já dar a eles uma finalidade. O comunismo enquanto uma espécie de humanismo desloca a essência do homem a uma essência produzida "na forma de seu trabalho ou sua obra". É por isso que pelas bases de um comunismo enquanto regime político tem-se o "[...] propósito de atingir uma comunidade de seres produzindo em essência sua própria essência como sua obra, e ademais produzindo precisamente essa essência enquanto comunidade" (p. 2). A essência produzida não se distingue da totalidade presumida. Deixar que o homem produza sua essência por sua produção é diminuir a descontinuidade entre os

\footnotetext{
${ }^{72}$ Id Ibid p. 2
} 
indivíduos. A comunidade pensada e idealizada pelo comunismo, essa que "desafastaria" as distâncias entre o seres ao dá-los um ponto comum é "uma de seres humanos [que] pressupõe que efetua, ou que deve efetuar, enquanto tal e integralmente, sua própria essência, que é em si o cumprimento da essência de humanidade" (p. 3).

Consequentemente, laços econômicos, operações tecnológicas e fusões políticas (em um corpo ou sob um líder) representam, ou melhor, apresentam, expõem e realizam sua essência necessariamente em si mesmas. A essência está em obra nelas; através delas, torna-se sua própria obra. Isso é o que chamamos "totalitarianismo", mas pode ser melhor nomeado "imanentismo", desde que não restrinjamos o termo para designar só certos tipos de sociedades ou regimes, mas sim ver nele o horizonte geral do nosso tempo, abarcando tanto as democracias e seus frágeis parapeitos jurídicos ${ }^{73}$.

É nesse sentido que a comunidade apresenta a si um corpo único. Ao aproximar de si seu trabalho, ou ao unificar os trabalhos de suas partes produzindo o mesmo resultado, a essência do que os une, a comunidade tornase um outro indivíduo, um só corpo cuja totalidade é cada uma de suas partes pela soma de suas qualidades, idênticas. O comunismo é um problema identitário. O "totalitarianismo", que pode ser um "imanentismo", é a presunção, primeiramente teórica, de que a essência do homem está nele mesmo, não independe dele, nem o transcende, não é inalcançável, nem está longe do alcance do que suas mãos produzem.

No entanto e apesar de o individualismo não ser a primeiridade, a comunidade, desde aí, seria um mero agrupamento, Nancy apregoa que "a experiência pela qual esse individuo passou, desde Hegel pelo menos, [...] é simplesmente a experiência do seguinte: o indivíduo pode ser a origem e a certeza de nada senão de sua própria morte" (p. 3). Isso significa que a comunidade, pelo fenômeno do "comunismo" indicaria uma resiliência de recuperar-se em um só corpo apesar de tantos choques a sua "sustentabilidade" e essência baseia-se justamente no fato de que sua substância é sua produção ou resultado, a imanência é o que está em jogo aí.

${ }^{73}$ Id Ibid p. 3 
A comunidade como uma dita figura da imanência permite a pergunta do que é o indivíduo então, sob essa lente. Para Nancy, a individualidade é "uma outra, e simétrica, figura da imanência: o absolutamente desligado por si mesmo, tomado como origem e certeza" (p. 3). Por isso, o indivíduo seria uma outra forma de absolutismo e totalidade. Para Jean-Luc Nancy, há quem veja na invenção e na cultura do individualismo, "senão no culto construído ao redor do indivíduo, o mérito irrefutável da Europa de ter mostrado ao mundo o único caminho de emancipação da tirania" (p. 3). Seria o indivíduo um mero deslocamento necessário da comunidade de um "comunismo" falho? Uma troca de imanência e absolutismo que historicamente ainda resistiam o aniquilamento?

O indivíduo, historicamente, é a ele reservado um nascimento desde a Antiguidade. Para alguns, a lírica foi esse nascimento. Desde que se começou a falar "eu". Para outros, o direito romano é a prova viva, com o surgimento da comunidade privada, de uma recém descoberta individualidade. É de Marx a crítica de que o indivíduo não pode ser anterior à comunidade, senão uma abstração do conceito de uma comunidade. Nancy o repete ao considerar que o indivíduo é nada senão "o resíduo da experiência de dissolução da comunidade. Por sua natureza [...] o átomo, o indivisível [...] o indivíduo revela que é o resultado abstrato de uma decomposição" (p. 3). Contudo, em Nancy, o indivíduo é o resultado de uma dissolução da tentativa frustrada de comunidade, ao passo que em Marx ainda havia esperanças de retomada do verdadeiro a priori da comunidade numa implementação natural que ia além de uma implementação, a comunidade viria pelo curso natural de um processo histórico que ultrapassava e ao mesmo tempo definia o progresso da humanidade.

De fato, se "o individualismo tende a esquecer que o átomo é um mundo" (p. 4), é pelo fato de a questão da comunidade estar de tal modo "ausente da metafísica do sujeito, quer dizer, da metafísica do absoluto para si mesmo - seja na forma do indivíduo ou do Estado total - que significa também a metafísica do absoluto em geral" (p. 4). Seja Estado ou indivíduo, ambos são figuras de uma requerida totalidade ainda não advinda, a comunidade está ausente de tanto uma quanto a outra. Isso é porque a dita "metafísica do 
sujeito" (haverá outra?) é uma metafísica da presença e presentificação do absoluto. De uma suficiência da presença e de sua independência (não é certo que Bataille tenha criado uma metafísica do erotismo? Não é subvalorizada sua proximidade com Hegel) a qualquer coisa que se relacione a ela. Para Nancy essa é uma metafísica do "ser como ab-soluto, como perfeitamente desvinculado, distinto e fechado: ser sem relação" que pode aparecer, de fato como se trata de uma metafísica, é necessário que apareça, tanto "na forma da Ideia, História, o Indivíduo, o Estado, Ciência, a Obra de Arte e por aí vai. Sua lógica será a mesma no tanto em que é sem relação" (p. 4).

No entanto, "a lógica do absoluto viola o absoluto. Implica-o numa relação que ele recusa e impede por sua própria essência" (p. 4). O absoluto implica uma lógica que nega o próprio absolutismo que promete. Para ser absoluto, algo deve ser em-si, sem relação com nada. No entanto, o absoluto não pode deixar de se relacionar com ele mesmo, implicando-o numa relação consigo que exclui o fora e a externalidade ao mesmo tempo que nega a própria ideia de uma separação ou absolução, pois que relaciona-se em-si, consigo e para-si, uma ideia de solidão. Contudo, "a relação (a comunidade) é, se é que é, nada senão o que desfaz, em seu princípio mesmo - e em seu fechamento ou em seu limite - a autarquia da imanência absoluta" (p. 4). Talvez por isso a tentação de afastar continuamente a comunidade de qualquer ontologia possível. Afastá-la de todo de uma metafísica da presença ao propôla somente enquanto promessa. A comunidade, excluída da metafísica do absoluto, desfaz a ab-solução do absoluto.

O que Nancy quer propor com uma revisitação à comunidade é que, talvez, o "Ser ele mesmo [venha] a ser definido como relacional, como nãoabsoluto [...] é o que em todo caso tento argumentar [...] como comunidade" ( $p$. 6). Em verdade, uma tal revisitação do tema da comunidade em Nancy é também um resgate reapropriativo de Heidegger. $O$ que Nancy propõe, no entanto, é um ser-comunitário a partir da singularidade e não da individualidade. 


\section{CAPÍTULO III}

Releituras, Literatura avant la lettre 


\section{Heranças e releituras da comunidade}

\section{Releituras do "ser-com" heideggeriano}

Contudo e apesar, talvez mesmo seja o caso de um "apesar", Heidegger em Ser e Tempo, de 1923, já havia ressaltado a importância de que o Ser fosse entendido em modos-de-ser e que aquilo que o definiria de modo mais largo e portanto mais originário - também diferenciava ontológico de préontológico -, aquilo que primeiramente definia o ser ontologicamente era o modo de ser-com. Isso vinha consonante com um projeto de reanalisar a importância da metafísica ocidental que, para Heidegger, havia esquecido propriamente o Ser, cuidando sempre, e ao invés, do ente. Isso para Heidegger é resolvido com um melhor entendimento de diferença ontológica, que é justamente saber reconhecer o que é pré-ontológico e o que pertence à seara da ontologia, com a distinção entre ente e Ser.

Não há, claro, como desatrelar o ser-com de uma relação intensa e originária com a morte. Nem desligá-lo de seus outros modos-de-ser, contudo menos originários porque derivados do ser-com. Outrora reduzido a mero ente, Heidegger pretende que o Ser, para ele, jamais discutido antes de seu livro, seja propriamente um ser-com. É somente nesse modo-de-se que pode-se falar em apresentação ou configuração de mundo para o Dasein em Heidegger. O ser-com de Heidegger não é comunitário. Ele é ainda o individualismo do consigo e a imaculabilidade do Dasein a quem a espacialidade ainda assombra.

O projeto heideggeriano foi acolhido com um esperança de um ideário de um ser-relacional. Nesse sentido, a proposição de um ser-"comunitário" por Jean-Luc Nancy é justamente a retomada de um ser relacional, e não absoluto como no fim das contas propõe Heidegger com a negação do ôntico pelo ontológico. Negar uma imanência não é necessariamente querer dizer uma transcendência. É apenas legar ao ser uma requerida ou necessária relação, que também não confunde-se com uma dependência. 
O êxtase [...] estritamente falando, define a impossibilidade, tanto ontológica quanto gnosiológica, da imanência absoluta (ou antes do absoluto e, portanto, da imanência) e consequentemente da impossibilidade seja de uma individualidade, no sentido preciso do termo, ou de uma pura totalidade coletiva. O tema do indivíduo e o do comunismo estão intimamente ligados à (e juntamente ligados na) problemática geral da imanência. Estão ligados em sua negação do êxtase ${ }^{74}$.

O êxtase como conceituado por Bataille serve para Nancy como contraexemplo da individualidade ou bem mesmo de uma imanência que é o pressuposto de uma subjetividade qualquer e de qualquer experiência que seja, cujo pressuposto é a subjetividade imanente. Como no êxtase há somente abertura e "transcendência", não há ali possibilidade de um sujeito que o experiencie, não há ali nem mesmo experiência possível.

Novamente, com Jean-Luc Nancy:

[C]omunidade não é apenas comunicação íntima entre seus membros mas também sua comunhão orgânica com sua própria essência. É constituída não somente por uma justa distribuição de bens e tarefas, ou por um equilíbrio feliz de forças e autoridades: é feita principalmente da partilha, difusão ou impregnação de uma identidade por uma pluralidade em que cada membro identifica-se apenas através da mediação suplementar de sua identificação com o corpo vivo da comunidade. No lema da República, fraternidade designa comunidade: o modelo da família e do amor ${ }^{75}$.

Nesse sentido, para a comunidade, cujas partes comunicam-se pela partilha do que lhes há de comum, essas partes tem em comum justamente a comunidade que Ihes une. Em resumo, para Nancy, há também que: "em sua história o Ocidente deixou-se cair em nostalgia por uma comunidade mais arcaica que desapareceu, e [deixou-se] deplorar uma perda da familiaridade, fraternidade e convivência" (p. 10). De maneira similar à "conceituação" do amor por Marguerite Duras em seu récit, em Nancy, "[o] que essa comunidade "perdeu" - a imanência e a intimidade de uma comunhão - está perdido

\footnotetext{
${ }^{74}$ Id Ibid p. 6

${ }^{75}$ Id Ibid p. 9
} 
apenas no sentido em que tal "perda" é constitutiva da própria "comunidade" (p. 12).

Há contudo ainda a necessidade de clarificar o pertencimento da morte à questão da comunidade. Por isso: "A pessoa plenamente realizada de humanismo comunista ou individualista é a pessoa morta"; continua-se que, "Em outras palavras, morte, em tal comunidade, não é o indomável excesso de finitude, mas o cumprimento infinito de uma vida imanente: é a própria morte consignada à imanência" (p. 13).

O motif da revelação, do ser-junto ou ser-com, e da
cristalização da comunidade em volta da morte de seus
membros, isto é em volta da "perda" (a impossibilidade) de sua
imanência e não em volta de sua assunção fusional em uma
hipóstase coletiva, leva a um espaço de pensamento
incomensurável à problemática da socialidade ou
intersubjetividade (incluindo a problemática husserliana do alter
ego) dentro da qual a Filosofia apesar de seus esforços
permaneceu cativa. A morte irremediavelmente excede os
recursos de uma metafísica do sujeito ${ }^{76}$.

A "perda" é uma representação passadista de uma impossibilidade atual e futura da imanência e, portanto, presença e existência de comunidade. É por isso que o lugar da comunidade é o de assumir a "impossibilidade de sua própria imanência [...], de um ser comunitário na forma de sujeito. Num certo sentido a comunidade reconhece e inscreve - esse é seu gesto singular - a impossibilidade de comunidade" (p. 15). No entanto, a perda é também a "morte de seus membros" em torno da qual a "civilização da comunidade" se revela e cristaliza-se; nesse sentido não há representação possível da morte, ou mesmo é pela morte que se vê a impossibilidade mesma de qualquer representação.

Em dado momento de La communauté desouvrée, Nancy sente-se responsabilizado de ter de mencionar a grande sombra que permeia sua revisitação de Heidegger pela ótica da comunidade e política.

${ }^{76}$ Id Ibid p. 14 
Fascismo ignóbil, e fascismo enquanto um dos recursos do capitalismo, esse fascismo abominável foi também uma tentativa de responder - abominável e ignóbil - ao já estabelecido, já sufocante reinado da sociedade. O fascismo foi o grotesco ou abjeto ressurgimento de uma obsessão com a comunhão; ele cristalizou o motivo de sua suposta perda e a nostalgia por suas imagens de fusão ${ }^{77}$.

Fascismo é um estabelecimento falseadamente transcendentalizado de um comunismo que não se pauta no porvir, mas tenta colocar em imanência (como qualquer comunismo, em verdade, fora da teoria) uma ideia de comunidade com mais apego à produção de sujeitos de uma comunidade que se vê em trabalho; tenta por em imanência algo que se revela apenas enquanto impossibilidade de imanência e, portanto, ausência. $O$ fascismo revela a relação inextrincável do comunismo com a individualidade e soberania.

Ao se colocar contra tudo o que "está aí", o estabelecido, ao se pautar num discurso da mudança, uma nova sociedade, e ao mesmo tempo emblematizar a família e continuidade reprodutiva como os símbolos do que já havia sido a fraternidade humanista, o fascismo aproxima-se de um entendimento de comunidade fundamentado numa ideia comunitária de transcendência regressiva, ou, ao menos um momento suspensivo de transcendência para uma "nova imanência", um novo "aí" que a um só gesto conserva e supera.

O comunismo é testemunho da congregação e comunhão enquanto esperanças de estabelecimento enquanto vontade de estabelecimento e instauração de uma nova ordem, nesse sentido ele é o estabelecimento como o assentamento da poeira e ao mesmo tempo a faxina do dia depois. Por mais bobo que possa parecer, é justamente a faxina a imagem mais adequada às obsessões comunitárias do fascismo. Ela é a mudança do "estabelecido", limpeza da poeira, e também a volta do que está "perdido" nos estados atuais, renovação, nostalgia e conservação.

\footnotetext{
${ }^{77}$ Id Ibid p. 17
} 
Tendo já dito que a comunidade não é senão uma comunidade de outros, e não de indivíduos por sua vez, Nancy, parecendo ecoar Husserl, se este fosse autoconscientemente analítico, self jesting, comenta o estatuto do outro para a comunidade, para a qual apenas identidade faz sentido:

\begin{abstract}
Esse outro não é mais um outro, mas um objeto de uma representação de um sujeito (ou de maneira mais complexa o objeto representativo de um outro sujeito para a representação subjetiva). A comunicação e a alteridade que é sua condição podem, em princípio, ter apenas um papel e status instrumental e não ontológico em um pensamento que vê o sujeito como a identidade negativa e especular do objeto, isto é, como uma exterioridade em alteridade ${ }^{78}$.
\end{abstract}

O outro para a comunidade é apenas uma derivação especular ou projeção redutora, uma representação objetiva de um sujeito "para a representação subjetiva". Deve-se conceituar, e primeiro diferenciar, indivíduo, singularidade e alteridade. Dessa forma, a individuação é um processo que "desapega entidades fechadas em si de um chão sem forma - enquanto que apenas a comunicação, o contágio ou a comunhão constituem o ser dos indivíduos" (p. 27). Enquanto que o indivíduo é uma decantação da comunidade, uma abstração de seu fracasso e uma decomposição de sua impossibilidade, para Nancy, a singularidade é de todo o contrário.

A singularidade talvez não proceda de nada. Não é uma obra resultante de uma operação. Não há processo de "singularização", e a singularidade é nem extraída, produzida ou derivada. Seu nascimento não tem lugar de.. ou como um efeito de..: pelo contrário, ele provê a medida de acordo com a qual o nascimento, como tal, é nem uma produção nem um autoposicionamento, a medida segundo a qual o nascimento infinito da finitude não é um processo que emerge de um chão [fond] ou de um fundo [fonds] de algum tipo ${ }^{79}$.

Tendo em vista que a individuação desapega do chão "entidades fechadas em si", comparada à singularidade, os indivíduos provém, advém, são

\footnotetext{
${ }^{78}$ Id Ibid p. 24

${ }^{79}$ Id Ibid p. 27
} 
produzidos. A singularidade não advém nem resulta ou deriva-se de qualquer processo. Nela não há fundo nem chão. Seu nascimento não é nem "produção nem autoposicionamento", como seria com o caso de uma consciência identitária.

Não há nada detrás da singularidade - mas há, fora dela e nela, o espaço imaterial e material que a distribui e a compartilha enquanto singularidade, distribui e compartilha os limites de outras singularidades, ou até mais exatamente distribui e compartilha os limites da singularidade - que é dizer da alteridade - entre ela e o limite mesmo ${ }^{80}$.

A singularidade é a alteridade. Ela é o outro. Por uma questão de seus limites, não há como bem dizê-la sem aporias. "O ser nunca é somente eu, é sempre eu e outros como eu"81.

O que sustém o lugar de uma "origem" é a partilha de singularidades. Isso significa que sua "origem" - a origem de comunidade ou a comunidade originária - é nada senão o limite: a origem é o traçamento das fronteiras sobre as quais ou ao longo das quais entes singulares são expostos. Somos semelhantes pois cada um de nós está exposto ao fora que somos para nós mesmos ${ }^{82}$.

Em outras palavras, a comunidade é antes "aquela ordem ontológica singular em que o outro e o mesmo são semelhantes [sont le semblable]: isto é, na partilha da identidade" (p. 34). Nesse sentido, "comunidade" é qualquer mais de um em que há outro e mesmo. A comunidade é a base de uma discussão ética.

Nancy nos lembra da incompletude da partilha.

Incompletude é seu "princípio", tomando o termo "incompletude" num sentido ativo, no entanto, designando não insuficiência ou falta, mas a atividade de partilha, o dinâmico, quer queiram, de uma passagem ininterrupta através de rupturas singulares. Isso é dizer, de novo, uma atividade sem trabalho e inoperante. Não é questão de fazer, produzir, ou instituir uma comunidade; nem é uma questão de venerar

\footnotetext{
${ }^{80}$ Id Ibid p. 27

${ }^{81}$ Georges Bataille apud Nancy: Id Ibid p. 33

${ }^{82}$ Id Ibid p. 36
} 
ou temer um poder sagrado - é questão de in-completar sua partilha. A partilha é sempre incompleta, ou está além da completude e incompletude. Pois uma partilha completa implica um desparecimento do que é partilhado ${ }^{83}$.

A partilha para Nancy no entanto é a comunicação. A comunidade cujo princípio é incompletude a partir da partilha, é uma comunidade da literatura.

"[L]iteratura" não designa aqui o que essa palavra ordinariamente indica. O que está de fato envolvido é o seguinte: que há uma inscrição da exposição comunitária, e que essa exposição, enquanto tal, pode apenas ser inscrita, ou pode ser oferecida apenas por meio de uma inscrição ${ }^{84}$.

Isso nos demonstra que a noção de escritura está intimamente ligada à comunidade. Não porque há comunicação em partilha, mas porque a comunidade expõe-se em uma inscrição. A marca inscrita é que designa o pertencimento à comunidade.

83 Id Ibid p. 35
${ }^{84}$ Id Ibid p. 39 


\section{Corpus literário}

\section{O erotismo é forma de entendimento-a-si}

Se Bataille em $O$ erotismo interroga o corpo enquanto excesso; e se propõe que este, em seu aspecto erótico, seja "dispêndio improdutivo", é senão para questionar a "unidade do homem" que o pensador francês assim argumenta em sua obra. Ora, por muito que se houve figuras de interesse ao surrealismo que, se para alguns poucos não-especialistas parecessem surreais, para outros, iniciados, seriam claros índices de um aspecto do ser do homem que os deslumbrava a estados indagadores sobre o homem e sua tarefa no mundo.

Lê-se no Manifesto do Surrealismo, publicado por André Breton em 1924:

O homem, esse sonhador inveterado, diariamente mais descontente com seu destino, tem dificuldade em acessar os objetos que ele foi levado a usar, objetos que seu desleixo pôs em seu caminho, ou [...] através de seus próprios esforços ${ }^{85}$.

Breton chama atenção à necessidade do Surrealismo que quer instaurar ao delinear o então estado do "homem" até a data de seu escrito; mas algo ultrapassa as especificações mundanas desse homem de que ele fala. Esse "homem" não é somente um conterrâneo francês, homem de seu próprio tempo, um possível leitor ou literato de gostos específicos.

"O homem, esse sonhador inveterado", é todo homem. Fala-se nele em aspecto geral, pois a determinação sintática é aqui representativa de uma aspectualização generalista. Temos portanto aqui o homem genérico que representa o gênero (genus) humano. Ele é ainda predicado com um aposto que não somente o explica, mas revela sua "essência": "esse sonhador inveterado" é um aspecto qualitativo que pertence a "o homem" pela referência anafórica e dêitica "esse". Quase vê-se apontá-lo com o dedo, indicando-o em

85 BRETON, 1969, p. 3. 
sua presença ali, ou aí: "o homem, esse".

Pela feliz ausência de uma vírgula entre esse e sonhador, tem-se "o homem, esse sonhador" como frase predicativa não copulativa. Vai sem dizer que não se trata de "esse homem sonhador", caso em que teríamos aquele homem que sonha como tópico. À diferença dessa frase, "o homem, esse sonhador", apesar da ausência de um verbo ser no presente do indicativo e na terceira pessoa do singular, é frase definidora do homem em seu aspecto geral. Não se trata portanto de uma apressada definição. Isto quer dizer que ser sonhador pertence ao homem não exclusivamente. É lícito que tenha ele outros aspectos e qualidades, contudo seja o adjetivo "inveterado" que dê a esse homem seu aspecto sonhador de modo arraigado; nisso, dá-lhe algo que talvez esteja em seu fundamento, para além de seus esforços enraizado nele.

Temos, até agora, que "o homem, esse sonhador inveterado" está "diariamente mais descontente com seu destino". O descontentamento do homem com seu destino se dá de maneira progressiva e escalonada. Sabemos ainda que o homem "tem dificuldade em acessar os objetos que ele foi levado a usar". Quase se vê um tímido normalmente inscrever-se na frase, como se o homem a ser descrito em sua generalidade estivesse apresentando dificuldades inesperadas em "acessar os objetos" que, contudo, "ele foi levado a usar". O fato de o homem ter dificuldades com esses objetos que não escolheu que estivessem em seu caminho, ou mesmo que estejam ali "através de seus próprios esforços", parece ser um estado de exceção ou, como sua "dificuldade" parece requerer, algo que imponha uma necessidade de resolução.

Os sonhos, desta maneira, não obsedavam os surrealistas por simples nonsense ou niilismo: "se nos recusarmos a jurar que alguma coisa que façamos em sonhos é menos significativo que algo que façamos acordados", lê-se no Segundo Manifesto do Surrealismo de 1929, "[...] como espera que mostremos qualquer ternura, mesmo tolerância, a um aparato de conservação social, qualquer que este seja?" (1969, p. 128). De nenhuma maneira o Surrealismo pode ser "acusado" de humanista, desde que em seus manifestos, as cartas de intenções são sempre a de aniquilar, fugir à regra, questionar a moral e testar a sociabilidade humana e suas convenções. Mas isso não significa que as preocupações com a ordem e caminho do homem fossem 
inexistentes.

De certo que o texto dos Manifestos seja um tanto fugidio, há, aqui e ali, alguma tentativa de definição de suas tarefas vindouras. Também não é o caso de estabelecer ou tentar demonstrar que as preocupações surrealistas fossem com o ser do homem, dado que Breton programou à "aniquilação do ser a um diamante, todo cego e interior, que não é mais a alma do gelo que do fogo ( $p$. 124)". O que intentou-se demonstrar é somente uma preocupação do Surrealismo, e o que tem de pertencimento ao modernismo francês, com o homem em seu aspecto geral. Não tendo esta de ser um comprometimento filosófico com a universalidade humana, já que as preocupações do Surrealismo com o homem limitam-se a querer "desafiá-lo a escapar em algum nível significativo das algemas universais [...] essas imagens atraentes da catástrofe humana [que] não são, talvez, mais do que imagens (id., p. 123).

No entanto, "demonstrar a qualquer preço a natureza barata das [...] antinomias [...] intencionadas a prevenir qualquer fermentação fora da regra da parte do homem" foi uma das provocações do Surrealismo às ilusões autoimpostas ao homem, ou que foram colocadas em seu caminho; e somente "dando a ele uma vaga ideia das ferramentas a sua disposição" (id. ibid.), é que se o exorta a escapar das "algemas universais".

De qualquer forma, sabe-se que "o surrealismo tentou provocar, do ponto de vista intelectual e moral, um ataque de consciência, do tipo mais geral e sério" (id., ibid.). De certo que isso não significa uma atitude acadêmica ou em relação aos pressupostos gerais do movimento. A tão temida atitude academicista a Breton e, em certa medida, qualquer atitude positivista que fosse levada a posicionamentos ideológicos evidentes, apesar disso, não deixaram de alimentar preocupações com o homem e suas formas de consciência.

Tudo tende a nos fazer acreditar que não existe um certo ponto da mente em que vida e morte, o real e o imaginado, passado e futuro, o comunicável e o incomunicável, alto e baixo, cessam de ser percebidos como contradições [...] procure tanto que alguém possa jamais irão achar outra força motivadora nas atividades dos Surrealistas que a esperança de achar e fixar esse ponto ${ }^{86}$.

86 Id lbid. p. 124 
Dessa forma, há ainda a "esperança de achar e fixar" um ponto em que as antinomias cessassem de ser percebidas "como contradições". Esse ponto que se quer fixar é a força motivadora mesma dos Surrealistas e implica, não há dúvida, numa resolução das contradições em unidade. As preocupações com o homem residem na motivação de levá-lo à consciência, seja atacando-a, seja mostrando-Ihe o que tem disponível a si. O que encaminha essa tarefa é "a crença nesse lampejo de luz que o Surrealismo procura detectar dentro em nós" (p. 126).

O fato é que não há de modo algum "negação do homem" tendo em vista uma negação do humanismo. Se não podem ser taxados de humanistas, o Surrealismo tem em comum com o humanismo a crença numa centelha dos homens, a busca desse "lampejo de luz" à revelia das sombras e uma tentativa de "fixar" um ponto, em cuja unidade resiste um sobejo da "essência" humana, visto no purismo obsedado pela limpeza das sombras. Certo é que essa "crença" no "lampejo de luz", contudo procurada e, ao que parece, ainda não encontrada, está por desvelar-se.

Isso é interessante de perceber principalmente na resoluta posição assumida pela crítica do modernismo francês. Aqui nos reportamos a Eliane Robert Moraes em sua obra $O$ corpo impossível, que se atenta para esse período, fazendo relacionar o Surrealismo com a questão do corpo humano para uma época em que não poucos artistas, dentro ou fora do movimento, tocaram nesse ponto; seria ele o ponto por fixar?

Moraes constata que para o movimento do Surrealismo a "saída humanista de afirmar uma suposta totalidade da vida estava fora de questão [...] nela se denunciava uma total indiferença pela particularidade dos seres concretos, de sua existência sensível e materialidade singular" (2012, p. 88). Escreve a autora que "se para contestar esse humanismo era preciso negar o homem, essa negação só viria a se tornar operante por meio de projetos que viessem a reconsiderar a vida sensível" (Id. Ibid. p. 88). Fica claro que, para a historiadora do movimento surrealista, a saída humanista não seria considerada; mas, seria questão de achar uma saída qualquer fosse ela?

O delineamento do projeto surrealista em Moraes toma importâncias de uma solução para um problema. O problema é homem, pois que "a saída do 
humanismo" foi uma tentativa de resolução desse problema. Agora, se o Surrealismo espelhou-se, mesmo que denegativamente, no humanismo, teria sido por causa de uma coincidência de tema, ou que se propusessem a resolver o mesmo problema?

Se, ainda, o projeto surrealista era voltar-se à vida sensível, como diz Moraes, é porque "[a]s guerras e suas assustadoras consequências acabaram por precipitar esses projetos", pois "num mundo em que a vida sofria tal ordem de ameaças, não havia outra forma de afirmar a existência sensível senão recolocando o corpo humano em questão" (Id. Ibid. p. 88). O ponto é que, invariavelmente, se ainda apregoa-se uma unidade, se resiste ainda na noite do humanismo uma esperança de um "ponto fixo" que se vê, ou se quer acreditar" ser visto, naquele "lampejo de luz" que Breton quer detectar, se, por fim, o homem é de qualquer modo definido, seja como for, seja mesmo como um "diamante", ainda se tem uma totalidade em vista.

Se a contestação do humanismo se dá pela "negação do homem", em que se fundamenta ainda visar a "vida sensível" e recolocar o corpo em questão? O homem, todavia não o do humanismo, ainda está em xeque na interpretação de Eliane Robert Moraes do gesto surrealista de evidenciar o corpo e a materialidade singular dos seres concretos; isto é, para que isto seja, e o surrealismo contraponha-se à "saída humanista" para a totalidade da vida e do homem cuja obra é a totalidade e sua essência, em que se fundamenta a saída de voltar-se para o corpo e a vida sensível? O que esperam os surrealistas acharem aí e a quem o que acharem será interessante se "era preciso negar o homem"?

Mesmo que Breton veja em Freud seu único alicerce teórico declarável ou digno de nota ${ }^{87}$, Moraes, a quem já era possível reconhecer o grau de identidade que há entre uma denegação e seu contrário de afirmação para o inconsciente, não faz essa ressalva, pois lhe é mais interessante manter o aspecto "humano" em negação para que se lhe siga uma afirmação consequente do aspecto material e corpóreo da vida "sensível" e para que tal afirmação ganhe dignidade de tese. É implícito que, para um tal gesto, as duas coisas precisem estar em polos opostos, num sistema em que o aspecto

\footnotetext{
${ }^{87}$ André Breton. Manifestoes of Surrealism. Trad. Richard Seaver \& Helen R. Lane. Michigan: The University of Michigan Press, 1969.
} 
humano e aspecto sensível estejam em relação, senão dialética, meramente opositiva.

Essa relação de corpo e seu oposto, seja que se lhe chame "espírito", "lampejo de luz", "humano" ou "alma", faz parte de um sistema metafísico e logocêntrico em que corpo e não-corpo, apesar de um relegado à lama e o outro à alma, são o absoluto mesmo da presença de um e ausência de outro; o lado ausente, contudo, acaba sendo o privilegiado, como de praxe. É lícito nos referirmos aqui ao trabalho de Jacques Derrida sobre essa questão: as antinomias ou os "pares opositivos" são sintomas do logocentrismo, braço operante da metafísica da presença.

Por essa instrumentalização do pensamento derridiano temos uma outra "saída", mas sabe-se que não é questão disso, ao esquema freudiano da denegação, ou a identidade entre negação e afirmação. Dito superficialmente, ao propor os "pares opositivos" como reiteração um do outro, Jacques Derrida os insere na lógica da mesmidade de que fazem manutenção; isso significa dizer que o contrário de um dado "fenômeno" só faz sentido como o apagamento e diferenciação (diferendo, diferência e diferir em sentidos verbais ativos) do mesmo; o gesto de diferir - substituinte da "diferença ontológica" heideggeriana e que, mais tarde na obra $A$ besta e o soberano, será condensado à uma diferença sexual e/ou linguística, gramatical originária na fórmula "Il, elle" - começa, contudo, como substituinte, ou enlutecimento, do processo de significação enquanto deslocamento infinito producente de significado pela operação semântica do signo linguístico.

Para Derrida, o processo de referência de um significante a um significado torna este último em um novo significante e esconde um processo de fundo que é o do logocentrismo, que opera em subníveis de troca valorativa entre ausências e presenças (a própria referência sígnica). Além disso, há, entre os significantes, níveis ordinários de uma esquematização hierárquica ou distribuição de valor; Derrida também observa os princípios de uma reduplicação de em que significantes como a voz são privilegiados em detrimento da depreciação de "significantes" como os grafemas. Isso resulta em, e de um ponto de vista analítico, advém de, uma absorção da parte do "significado" de conceitos como os de "sentido", "objeto", "coisa", "valor aproximativo" etc. 


\section{Diacronia do corpo: signo corpóreo}

De todo modo, no entanto, é "o corpo humano" que deve ser recolocado em questão. Moraes vê nas várias representações do corpo fragmentado nesse período "uma recomposição que parecia interminável". As guerras e suas consequências teriam, junto ao humanismo fracassado em cujo nome atrocidades foram feitas, esgarçado o homem de sua individualidade e totalidade. "Não é de todo estranho que o homem perca a cabeça no limiar da Segunda Grande Guerra" (p. 89). Moraes interpreta a fragmentação do corpo humano e suas representações monstruosas, dispersas, como um retrato da fragmentação histórica de que os modernistas franceses se utilizaram para um ataque de consciência.

O decapitado é a imagem que retratava o estado capital das aniquilações bélicas e uma consequente necessidade de instauração de uma perdida unidade se fazia necessário. $E$, se a posição de Bataille frente ao Surrealismo estava incerta e a relação entre esse movimento e o autor que muitas vezes funcionou como seu crítico estava rodeada de polêmicas, Bataille ainda figurava como a cabeça do modernismo francês de que o Surrealismo era apenas uma das expressões.

Daí para frente o ser humano foi totalmente desfigurado, desmontado e desarticulado: as mãos separaram-se dos braços, os pés desligaram-se das pernas, o ventre adquiriu autonomia, os olhos e as orelhas destacaram-se do rosto, os órgãos internos desagregaram-se uns dos outros. Uma vez fragmentado, só lhe foi possível recuperar a unidade do corpo através de formas híbridas e monstruosas ${ }^{88}$.

A descrição de Moraes dessa fragmentação e desmonte do corpo humano é sem dúvida inspirada nas representações pictóricas de André Masson, Pablo Picasso e Hans Bellmer, por exemplo. As "formas híbridas e monstruosas", que para Moraes são tentativa de "recuperar a unidade do corpo" talvez sejam um aceno aos desenhos bestiais de Max Ernst. Esses são certamente autores que Moraes analisa e relaciona ao modernismo francês e o ${ }^{88}$ MORAES, 2012, p. 88. 
Surrealismo de que foi grande parte.

Contudo seja de fato o corpo "humano" que ganha destaque no burburinho estético desse período - Antonin Artaud e Georges Bataille são testemunhas de que o corpo estava consonante não só ao projeto surrealista, mas ao modernismo francês de modo geral. Discordamos que essa retomada do corpo fosse motivada por uma "negação do homem", mesmo que por causa das atrocidades feitas em nome do humanismo, nisso Moraes apoia-se em Annie Le Brun, historiadora do movimento surrealista.

Se em um primeiro momento os surrealistas parecessem negar tudo e se esquivar de qualquer categorização ideológica, parece ainda um pouco implausível que quisessem "negar o homem" ou mesmo que as representações fragmentadas do corpo remetessem a um espírito de época em sintonia com sintomas de perda e aniquilação da identidade e individualidade aos estertores da guerra.

Em suma, ver nas representações do corpo fragmentado algo de uma tentativa de reconstituição de uma totalidade perdida, apressadamente interpretada como a individualidade e consciência esgarçadas pelas guerras e de um homem antecipando-se numa nova desarticulação com seu destino histórico, é, sem dúvida, pressupor o corpo humano como signo.

Além disso: a historicização do corpo vem como princípio de um método historiográfico e textualista em que o corpo como tema deve ser postulado, tematizado e, por isso, posto segundo ordens de pensamento epistêmicas e históricas; as duas se confundem, certamente; a apropriação hermenêutica do corpo pela crítica em 0 corpo impossível se dá apenas por sua pressuposição sígnica, unitária e representativa; o que, sobretudo, implica na dúvida de como pode o corpo ser desfigurado, desmontado e desarticulado se, para que seja assim predicado e entendido em retrospecto, deve ainda pertencer à esfera semântica de um objeto, epítome da unidade e integração pura, para que, entendido desta maneira, ou de qualquer forma entendido, figure-se numa episteme e história.

Certamente que o tratamento metodológico do corpo enquanto signo não é novidade absoluta em Moraes. Em História do corpo, conjunto de textos organizados por Jean-Jacques Courtine, vê-se uma historiografia desse tema estender-se em três volumes desde a Idade Média, o Renascimento e a 
Modernidade do pós-guerra. Courtine assinala a importância de um tratamento do tema que respeite as vantagens que estudar o corpo implica. Ele ressalta a interdisciplinaridade do tema e os aspectos e pontos de vista que essa porosidade permite: corpo fisiológico, político, comunitário, médico, corpus literário, pictórico, obra, direito do/ao corpo, poder sobre corpos, corporeidade do signo etc. É justamente nesse último sentido que se dá o espaço de contraposição que tentamos demonstrar aqui.

Pela confusão entre objeto e integridade, totalidade, individualidade e unidade, a corporeidade do signo é também o caráter sígnico do corpo. Há ademais um aspecto de suficiência que é comum ao objeto e ao corpo. Nada Ihes falta se são considerados idealmente enquanto concretude de dois braços e duas pernas em cada lado de um eixo formado de cabeça, tronco e sexo. Em nossa interpretação, é isso que permite o tratamento de corpo enquanto signo e é também o que motiva a interdisciplinaridade dos estudos sobre esse tema. Não que o corpo seja tratado como signo por sua constituição fática, mas porque só pode ser cognizado, cogitado, se entendido; e entendido se concebido como objeto.

\section{Outras "saídas" teóricas: corpo como figura extensa}

Em Le toucher - Jean-Luc Nancy, Derrida expõe uma breve "história" da questão do toque; o que, textualmente, é deslocado para as figuras do toque, a extensão, a espacialidade e, propriamente, a figura. Há quatro concepções da figura para pensar o corpo sob o ponto de vista da imagem.

1. Figura como a forma da extensão: Nancy já disse: "figura (isto é, extensão, medida) e sem-figura (isto é, pensamento sem medida)";

2. Figura como modo/maneira de fazer, modo do fazer e feitura [façon de faire, façon du faire];

3. Figura como tropo;

4. Figura como cara [face] ou rosto $[\text { visage }]^{89}$.

89 DERRIDA, 2005, p. 30. 
Nesse sentido, Eliane Robert Moraes compreender o corpo como desfigurado, desarticulado e desmontado nas representações pictóricas do modernismo francês só faz sentido se o corpo se constituísse, normalmente, enquanto articulação, objeto íntegro e "figura". Das quatro concepções apresentadas acima, nenhuma se aplica ao sentido de "des-figurado" do texto de Moraes. Ali, "des-figurado" assume o sentido de esgarçado, fora de seu estado normal etc. No entanto, seria o caso de que o corpo fosse "compreendido", ao menos conceitualmente, enquanto uma "forma extensiva", "figura como tropo" e medida. É isso que nos sugere Jacques Derrida em Le toucher - Jean-Luc Nancy.

\section{O corpo histórico é um sujeito deslocado}

\section{Corpo como presença reapropriada}

Um outro ponto de interesse é o posicionamento histórico que Eliane Robert Moraes assume em seu livro. Na contracapa é dito que é uma originalidade da autora o tratamento desse tema, modernismo francês e Surrealismo do ponto de vista do corpo, originalidade que é justamente a de entreter história e estética em um diálogo. É tão logo que percebemos não haver outra possibilidade metodológica de discussão acadêmica para o modernismo francês e o Surrealismo, que não a histórica, que nos damos conta de que a originalidade do livro talvez de fato não se assente aí; com o corpo talvez seja-nos necessário mais esforço para perceber que o tratamento histórico dado a esse tema por Eliane Robert Moraes também não constitui em nada original.

Sabe-se que o objeto de uma História de qualquer coisa só pode ser senão o mesmo objeto de uma epistemologia, isto é, um objeto primeiramente. A apreensão do conhecimento histórico é, antes, a apreensão de um objeto do conhecimento que deve, sobretudo, ser cognizável, compreensível e definivel em seus limites e partes esperando uma síntese - que não se dá senão pela 
assunção à unidade. Reportamo-nos aqui à aproximação que Jacques Derrida faz entre história e saber, apesar da "dissociação ou oposição" relacionada entre elas "em seu caminhar comum" (1973, p. 12); em Gramatologia, diz Derrida que "a história e o saber, istoria e episteme, foram determinados sempre (e não apenas a partir da etimologia ou da filosofia) como desvios em vista da reapropriação da presença" (Id. Ibid. p. 12).

Contudo seja o diálogo entre história e a estética da vida sensível do Surrealismo, notadamente o corpo humano, a originalidade de aproximação ao tema do livro de Moraes, o tratamento histórico-acadêmico do corpo visa a uma tal reapropriação da presença; isto porque em sua análise, o corpo mantém correlação com o indivíduo mesmo que o "carrega", beirando mesmo à coextensividade e equivalência.

Dessa maneira o corpo é símbolo da autossuficiência, independência e unidade que são os predicados da individualidade autoconsciente que se acostumou chamar de sujeito. De fato "o homem", conceito diferente, é a síntese de uma individualidade fática com a idealidade presumível a partir da generalização universalizante de um esquema subjetivo que se fundamenta nas ideias de liberdade, independência e consciência de discurso; estas duas últimas servem de sustento à primeira, objetivo máximo de regulação e controle de uma tal ideia de corpo sempre anteriormente imbuída de um sentido valorativo e ideal cuja pertença à ideia de subjetividade é identificável a partir da sobreposição que se verifica entre corpo e subjetividade, isto é, ambos pautam-se em esferas de discussão sobre a "inalienabilidade" dos conceitos de liberdade, direito à subjetividade e subjetividade de direito ${ }^{90}$.

Dito nesses termos, a "negação do homem" da parte dos surrealistas de que fala Moraes não pode deixar de ser nuançada em "sublação" do homem. Sua "negação" não é senão sua reapropriação em outro; como no gesto de "superação" hegeliano, que implica uma negação e uma assimilação do "negado" em outro que o contenha e "supere", mantendo-se o mesmo; se alguns veem na aufheben hegeliana um paralelo, senão imperfeito, com a

${ }^{90}$ Esse é precisamente o tópico quando se vem a falar sobre o corpo como espaço, visto que apenas categorias extensíveis (materiais e "sensíveis") podem ser dotadas de valoração passíveis de distributividade de poder regulador. É por esse viés que o corpo humano assume um lugar de limbo entre o Estado e a nação (parte das cidades, parte do país), dado que os limiares da nação geograficamente definida em linhas fronteiriças não deixa de se estender a cada vez que os corpos partícipes de uma nacionalidade comunitária as ultrapassam. 
teoria do ritmo, é porque a "sublação" é em-si um gesto de "alteração" e "iteração" de que se ressalva uma passagem ao outro (iter, alter), contudo pela negação, que, no entanto, repete-se no mesmo.

Há outros complicadores nessa aproximação histórico-acadêmica ao "corpo humano"; primeiro, ressalte-se que ele é visto no livro de Moraes como mero aspecto da "vida sensível" e da "singularidade material" de seres concretos. Que a autora veja na figuração estética do corpo - através de suas representações de desfiguração e desmonte durante Modernismo francês - uma obcecada procura pela unidade do indivíduo que se fragmentara pode parecer lógico e defensável.

\section{Aufhebung - sujeito enlevado a corpo}

Uma tal figuração de corpos desfigurados que se remete a sujeitos fragmentados implica, no entanto, em supressões de uma série de argumentos anteriores à conclusão, que agora se vê que é apressada; primeiramente, assume-se uma certa correlação entre corpos e sujeitos que, apesar de relacionável pela sua familiaridade ao indivíduo, não constitui o mesmo conceito.

Ademais, há pontos inexplicados, e talvez de todo inexplicáveis, na passagem de uma certa negação do homem, cuja motivação, contudo, é insistir na humanidade através de uma maior atenção aos corpos, para sua consequente fragmentação estética, seguindo-se para uma reunião dessas partes desconexas em imagens bestiais; e, sobretudo, propor que o o artista do período, com a proximidade vindoura da Segunda Guerra, prevesse uma nova cisão do homem com sua individualidade, simbolizada pelo desmonte do corpo humano, é ir um pouco longe demais até mesmo em contraste com as outras pressuposições de uma mesma ordem de inexplicabilidade.

Em suma, ver nas figurações desfiguradas de corpos uma tal fragmentação do sujeito histórico é pressupor uma relação entre estética e história cujas inúmeras variáveis contextuais e suas consequentes categorizações para o estabelecimento da empreitada exigem epistemologias que não podem ser estabelecidas; sequer podem ser contabilizadas e descritas em seus níveis e modalidades de atuação e função num suposto processo de 
espelhamento entre imagem e vida que em muito supera em exagero as teorias de representação vigentes.

Isso é dizer que a sistematicidade necessária para o assentamento ajuizável de uma tal asserção participa da ordem da contingência absoluta. Quanto a mais profundos aspectos de uma aproximação histórica ao tema do corpo, é suficiente dizer que este é justamente seu erro.

A historicidade que assemelha corpos de seu tempo ao espírito do tempo em que, espacialmente, se econtram ou estiveram necessita de um conceito de história que é progressivo, acumulativo e não-acidental, pois que, para que seja defensável que sujeitos fragmentem-se (unidade, individualidade e autossuficiência esgarçadas), é preciso que os tempos passados funcionassem como completamente alheios a esse cenário e que fossem de todo diferentes, já que uma tal ideia de história baseada na logicidade de acontecimentos inexoráveis só ganha autenticidade num sistema histórico de irrepetibilidade, cujo sistema não-contingente exclui quaisquer dois acontecimentos ou situações gerais idênticas pelo próprio fato de que a suficiência e organicidade que rege esses princípios repudiam a repetição, o excesso e o resto.

\section{A poesia de Safo de Lesbos}

\section{Contraexemplo da historicidade do corpo}

Que qualquer coisa anterior ao Modernismo, face à Europa, frente à literatura e antes das campanhas tivesse figurado "um corpo" desmontado e fragmentado seria inconcebível nesse estado de conclusões, dado que apenas um entre-guerras, uma Europa dividida e uma França imperialista reúnem as circunstâncias únicas e justas para que uma tal autocondescendência tome lugar. Que apenas esse conjunto premente e previdencial de acontecimentos permita o luxo do desmonte e decapitação é, sobretudo, porque necessita-se de uma subjetividade prévia que assentasse as possibilidades de uma 
"fragmentação", só compreensível quando se tem a noção de algo íntegro para a temida disjunção.

Não seria o último gesto soberano de uma subjetividade desejosa de totalidade poder tomar controle de sua própria desunião e desajunte?

Safo, alguns séculos anterior a esse estado de espírito, cantava:

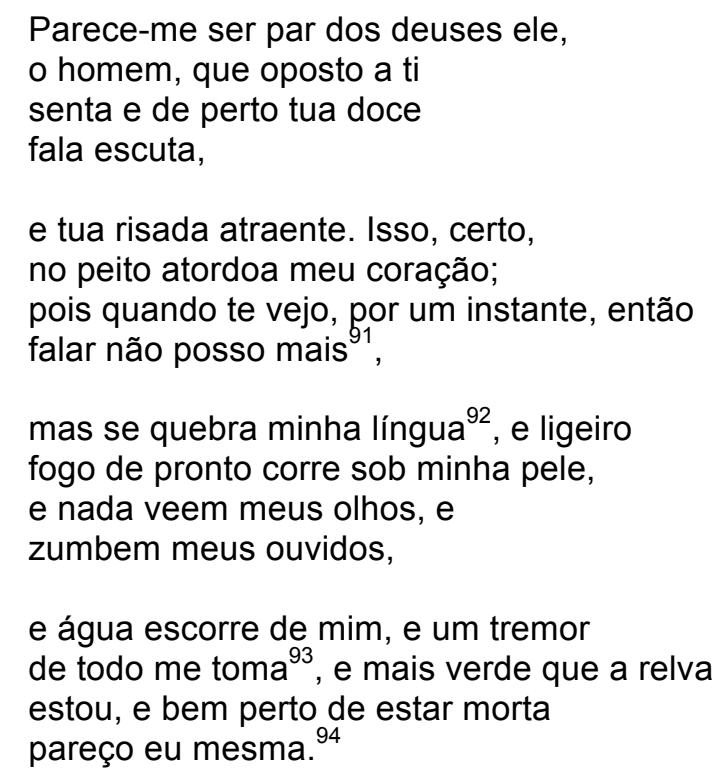

A mise-en-scène nos posiciona ao lado do enunciador. Vemos um homem "divino" sentado oposto a quem o poema parece culpar pelo estado descrito subsequentemente. A "risada atraente" desencadeia o atordoamento que vemos tão intricadamente detalhado. Mas é sem dúvida a visão de quem ri que engatilha o "então falar não posso mais, mas se quebra minha língua, e ligeiro fogo de pronto corre sob minha pele, e nada veem meus olhos, e zumbem meus ouvidos". Safo nos dá uma descrição fisiológica de um estado de êxtase e entorpecimento através de uma linguagem rítmica e paratática.

De fato, depois da visão daquela que ri, empregam-se apenas coordenadas a cada linha: "mas se quebra minha língua, e ligeiro fogo de pronto corre sob minha pele, e nada veem meus olhos, e zumbem meus ouvidos, e água escorre de mim, e um tremor de todo me toma"; até aqui, temse um estado extático que, pela progressividade dos elementos coordenados

\footnotetext{
${ }^{91}$ Conforme tradução de Joaquim Brasil Fontes, id. notas posteriores: "no instante em que te vejo: dizer não posso mais/ uma só palavra" (2003, p. 21).

92 "a língua se dilacera" (id., ibid.).

93 "um frio suor me recobre, um frêmito do corpo/ se apodera" (id., ibid.).

${ }^{94}$ No corpo do texto: trad. de Giuliana Ragusa (2013, p. 112-113).
} 
aditivos, parece assumir um aspecto sincrônico, como se espaço e tempo também cedessem ao erotismo do riso. À estrofe final, mais conectores cuja repetição confere ritmo e rapidez às linhas: "e mais verde que a relva estou, $e$ bem perto de estar morta pareço eu mesma". Na última linha, o recurso aditivo e enumerativo do conector gera um efeito de parada abrupta. A cadência vocálica dos enumeradores dá impressão de um alargamento do estado descrito pela repetição que vemos chegar tão logo ao fim.

Até a terceira linha da segunda estrofe, temos estruturas mais hipotáticas e complexas, cuja finalidade parece ser não rítmica como a descrição do êxtase, e sim mais consciente, colocando em termos espaciais e de ordem de acontecimento e causalidade junto a observações de qualidades, tudo referente a juízos de um ponto de "consciência" que recolhe os fatos e os ordena. "Parece-me ser par dos deuses ele, o homem, que oposto a ti senta e de perto tua doce fala escuta, e tua risada atraente. Isso, certo, no peito atordoa meu coração; pois quando te vejo, por um instante, então [...]".

Listemos as ocasiões:

1. "Parece-me": verbo de abertura, faz tudo referir a ajuizamentos e observações; o que se segue diz respeito ao enunciador e sua "opinião".

2. "ele, o homem, que": subordinada explicativa ou adjetiva, a depender da vírgula - pontos gráficos são um problema no manuscrito original grego.

3. "oposto a ti": locução adjetiva participial que tem matizes adverbiais por ser índice de espacialização na cena.

4. "de perto": adjunto adverbial; espacialização.

5. "doce fala": sintagma nominal de predicado e nome; o adjetivo diz respeito a uma qualidade subjetiva da fala que coincide com os adjetivos predicados a Eros.

6. "risada atraente": sintagma nominal de predicado e nome; o adjetivo refere-se aos dons de atração da risada; reporta-se em segunda instância a um epíteto que 
somente Afrodite recebe nos Hinos homéricos: philommeidés ("amante dos sorrisos") ${ }^{95}$.

7. "Isso, [...], no peito atordoa": substitutivo gramatical referente à "risada atraente" e adjunto adverbial de lugar; espacialização interior e corpórea que indica o campo de atuação do efeito atrativo do riso.

8. "pois quando": índices subordinadores, um explicativo; outro, temporal; ambos ordenadores ao discurso e à narrativa.

9. "então": índice explicativo ou de valor aditivo e também de valor adverbial, como em "e naquela hora"; ordena o discurso e a narrativa.

Já quanto a descrição do êxtase, ou arrebatamento, listemos as ocorrências:

1. "e ligeiro fogo": adjetivo assume valor adverbial da ação de "correr".

2. "de pronto corre": a ação é duplamente qualificada em seu aspecto súbito e rápido.

3. "sob minha pele": enfatiza-se os pronomes possessivos minha pele, meus olhos, meus ouvidos.

4. "nada veem [...] olhos": os sentidos se agitam ou cessam por metonímia às partes do corpo a que se referem; a descrição assume dessa forma um caráter físico e imagético. O resultado é que se vê olhos, ouvidos, pele, ou melhor, os efeitos do êxtase; em vez de uma descrição abstrata e sinestésica, tem-se a dinamicidade e percepção sincrônica do próprio êxtase.

5. "de todo me toma": novamente os adjuntos adverbiais ou descrevem a ação, e não espacializam a cena

${ }^{95}$ Giuliana Ragusa, 2013, p. 103, nota 5. 
ordenadamente, ou substituem o valor semântico de um adjetivo, como "inteira".

6. "mais verde que a relva": a relva é um índice relativo à pradaria, espaço de Eros.

7. "bem perto": ao contrário dos adjuntos adverbiais das linhas relegadas à mise-en-scène, aqui o "bem perto" refere-se não à cena, mas ao porvir fora do poema.

Quanto à imagética do êxtase no fragmento 31, lembra-se da estrofe 39 do canto $\mathrm{V}$ de Os Lusíadas, que começa com "quando uma figura / Se nos mostra:

\footnotetext{
O rosto carregado, a barba esquálida, Os olhos encovados, e a postura Medonha e má, e a cor terrena e pálida, Cheios de terra e crespos os cabelos, A boca negra, os dentes amarelos.
}

A descrição do gigante Adamastor se dá por frames, e, por isso, vemos antes suas partes desconexas de um todo; este só se apreende em fragmentação.

"O rosto carregado" não nos é mostrado, é antes velado por um qualificador que se refere à totalidade da figura; "barba esquálida" repete o peso figurativo de "carregado"; ao enfoque imagético, primeiro nos "olhos", depois na "postura", pouco interessam as qualidades de "encovados" e "medonha e má". Entre a descrição adiantada "a cor terrena e pálida, cheios de terra e crespos" antes da coisa a que se refere, "os cabelos", a imagem retarda-se e torna-se menos concreta. Retoma-se a agilidade e a desfiguração figurativa do monstro em "a boca negra, os dentes amarelos", por um paralelismo qualitativo, "negra... amarelos" que também concede variação à imaginação, pois "a boca... os dentes" referem-se a imagens separadas cuja síntese é contrastiva.

Ainda melhor: a sucessividade da linguagem verbal cria a visão disforme do monstro. Como em Safo, cuja síntese figurativa, o êxtase, é somente apreendido cognitivamente pela separação e sucessividade de imagens 
concretas como "olhos", "pele", "ouvidos". A "síntese" de um corpo arrebatado pelo desejo extático só é conseguida por uma fragmentação imagética e metonímica cujo propósito é figurativo e, portanto, mais permissivo a interpretações outras, pois pode ser reformulado discursivamente. Assim como "nada veem meus olhos" pode ter conteúdos comunicativos vários que se estendem além da imagem, a descrição do êxtase em Safo antes se vê que se deixa entender e só é figurada pela mediação fragmentadora da linguagem, que produz imagens isoladas de um desmonte.

\section{Cotejo à hermenêutica do êxtase segundo Leo Spitzer}

Em seu livro Três poemas sobre o êxtase Leo Spitzer analisa, como está claro desde o título, três poemas a sua escolha; ele privilegia John Donne, San Juan de la Cruz e Richard Wagner e sua análise ternária dos poemas é sucinta e cuidadosa. O que não está por sua vez tão claro é o uso destemido da pequena preposição "sobre", palavra, indicial na frase, que passa quase despercebida. Esta é uma pressuposição de Spitzer, uma das muitas de que lança mão sem fazer alarde, talvez para que não Ihe percebam o gesto, talvez pela arrogância disfarçada do que propõe e, que pode propor, de tal maneira, por sua posição e lugar na crítica.

En una noche escura de San Juan de la Cruz e Tristan und Isolde, o ato III da ópera de Richard Wagner acompanham, na análise de Spitzer, The Extasie de John Donne. Este último é o primeiro sob a lupa e o mais duramente criticado pelo autor, que lega o que considera seu puritanismo de expressão à crença protestante de Donne. San Juan de la Cruz é mais poupado e Spitzer, que é judeu vienense, the reserva comparações ao Cântico dos Cânticos, poema de tradição bíblica judaica, apesar de ressaltar que o monge e santo de la Cruz pertence ao mais declarado "catolicismo místico".

É enquanto o "sábio poliglota e polemista dos mais temidos" se debruça em comentários a respeito da diferença entre as concepções judaicas e católicas sobre o corpo que se percebe que os três poemas escolhidos pelo crítico austríaco, que este rapidamente diz serem sobre o êxtase, formam uma espécie de pano de fundo, e objetos motivadores, para uma discussão de 
teodiceias líricas de três tempos e, mais importante, de três correntes religiosas e filosóficas diferentes.

São estes: o protestantismo assexuado de John Donne; o catolicismo místico e a defesa de uma encarnação da senda gnóstica de San Juan de la Cruz, ambos sempre cotejados às concepções judaicas "menos metafísicas" de Cântico dos Cânticos ${ }^{96}$; o comprometimento a Gesamtwerk de Richard Wagner, que, depois de de la Cruz soa como uma leitura nietzschiana de um "misticismo" supraindividual e Lust inconsciente, mais freudiana que Freud, um "erotismo santificado", o que Spitzer chama de "ideologia wagneriana" (2003, p. 85).

A esse misticismo supraindividual, Spitzer contrapõe duas percepções teológicas sobre a carne e o espírito: a teologia de um "Deus pessoal" do catolicismo espanhol de San Juan de la Cruz - que, para Spitzer, é um cristianismo cujo acento recai mais fortemente sobre a carne - e a comunhão espiritual entre duas almas apesar do corpo advinda do protestantismo de John Donne. Dessa forma, os três tipos de êxtase de que tratam os três poemas sobre o êxtase analisados por Leo Spitzer são, na verdade, três formas de entendimento religioso e estético sobre a relação entre corpo e espírito.

Para a primeira parte de sua exposição hermenêutica, em que analisa The Extasie de John Donne, Spitzer sustenta que não se pode "escapar à impressão de que o poeta procede [...] à maneira de um fiel que pretende inculcar em seu público as convicções arraigadas em sua mente" (id., ibid., p. 45). Continua ele que sente-se no poema de alguma maneira que "o próprio Donne, a despeito de sua tentativa de justificação da carne, tinha mais convicção íntima da realidade e da beleza espiritual do que da necessidade do corpo para essa união" (id., ibid., p. 50). Isso porque, segundo Spitzer, "o último terço do poema dedica-se inteiramente a uma justificação do corpo: uma vez que este deve ser abandonado para que a alma conheça o êxtase", claro que esta é uma interpretação do crítico e continua ele, "poderíamos supor que o corpo é apenas um empecilho para o espírito" (id., ibid., p. 44).

Isso nos leva a pergunta: o corpo extático em fragmento 31 de Safo é tema ou mediação do êxtase? O corpo se deixa imaginar ou é o que possibilita

\footnotetext{
${ }^{96}$ É lícito ressaltar que Spitzer coteja a encarnação da senda cristã em de la Cruz com a diferente concepção de corpo/espírito para o Judaísmo.
} 
a imaginação mesma do êxtase? Não há abandono do corpo em Safo em parte alguma, o que se vê no fragmento 31, de fato, é quase o contrário. O corpo, apesar de sob efeitos do "solta-membros", experiencia um afeto fisiológico, morfológico.

\section{Comunidades líricas}

\section{Respostas de Safo à comunidade e corpo}

Em Safo não há "corpo" como reapropriação de presença. Como sujeito, dito em outras palavras. Georges Bataille tem uma concepção de êxtase que permitiu leituras de Jean-Luc Nancy e Blanchot diferentemente. Blanchot vê no êxtase uma possibilidade de comunicação comunitária que se inscreve em uma inatualidade de comunidade e comunicação.

O êxtase é para Nancy a contraprova da individualidade e experiência. É o gesto teórico que o permite propor um ser-com menos absoluto que o de Heidegger e avançar sua teoria ontológica da comunidade a partir de aspectos ônticos. A singularidade que ele aproxima da alteridade permite um sercomunitário de relação, e não de absoluto e individualismo como o Dasein heideggeriano.

Safo não representa um êxtase, pois isso seria colocá-la em um lugar de representação do erotismo enquanto entendimento-do-ser. Como o erotismo pressupõe o êxtase, com ambos, pressupõe-se um corpo que é um espelhamento do sujeito e, junto a ele, espelhamento de totalidade, individuação, completude e integridade absoluta. O corpo erótico, extático, a partir de Bataille e pela leitura de Eliane Robert Moraes, é somente uma aufhebung do sujeito. É um melhoramento do sujeito e um gesto reapropriativo de sua presença.

Os fragmentos sáficos impõem mudar a concepção de corpo. Fazem necessário entender corpo não como completude objetiva, individuação. $O$ corpo entendido desse modo é uma figura de absolutismo e soberania deslocada. Corpo não deve ser a metonímia de um sujeito. No entanto, o texto 
literário para a modernidade sempre o foi. A corporeidade textual, a inscrição em uma página, para a modernidade e contemporaneidade crítica da literatura, não passa de uma metonímia de uma consciência, intencionalidade de consciência, atestado de uma já-presente presença. Isso é o resultado de um entendimento estruturalista e sígnico de corpo textual.

Daí resulta um entendimento do texto literário como deslocamento de uma soberania assegurada a sobreviver por sua "obra". Faz-se necessário uma nova concepção de corpo, corpo textual, político, estético, corpo de inscrição, literalidade, corpo-suporte. Uma concepção de corpo que prescinda das ideias absolutistas de "completude", "autoconformidade", "individuação", "integridade" etc. Com a revisão da ideia de fragmento que Safo possibilita, corpo deverá ter seu a priori pela incompletude, falta e não-objetualidade, que não são seus contrários, mas são aquilo que o possibilitam desde a ameaça e a promessa.

Em Safo a comunidade é feminina. Os nomes que a rodeiam e que prevalecem em sua poesia são de mulheres. Ela permite outra concepção do "feminino" que não de um excesso a que se deve domar, apassivar, controlar violentamente. A comunidade em Safo é também uma inatualidade que se realiza a partir de sua inoperância. Contudo, ela é presumida pelo texto enquanto documento. Isso demonstra que a "comunidade sáfica" de mulheres adoradoras de Afrodite é já uma redução do "absolutamente outramente" do corpo textual e estético de Safo a uma mesmidade conformadora às comunidades de propósito. A inoperância da textualidade de Safo demonstra o melhor da comunidade inoperante e inconfessável. A comunidade que a comunidade deveria ser, sem o individualismo absolutista que se sente em Blanchot; a comunidade sáfica é (por falta de provas) a atualidade da ausência de obra (ela é somente incompletude e inalcançável presença de "intencionalidade", de "querer-dizer", de "contexto"), a atualidade da inconfessável partilha. 


\title{
Membros da comunidade sáfica
}

"Agora traz-me Anactória à lembrança, a que está ausente ${ }^{97}, \ldots$ "

Aqui de fato aquilo que se chama "tortamente" de membros demonstrase em sua impossibilidade de indivíduos à espera da partilha impossível. Haverá palavra feminina para "membros"? É desde aí que se tem a inatualidade de individuação comunitária. As supostas participantes do "grupo de Safo" estão sempre ausentes. No trecho em epígrafe, Safo quer recordar-se de Anactória.

As participantes de seu grupo estão sempre ausentes, quase sempre se sabe de sua participação no "grupo de Safo" pela lembrança de sua estada e presença em um momento em que se sente a ausência delas, ou em um momento de partida e despedida.

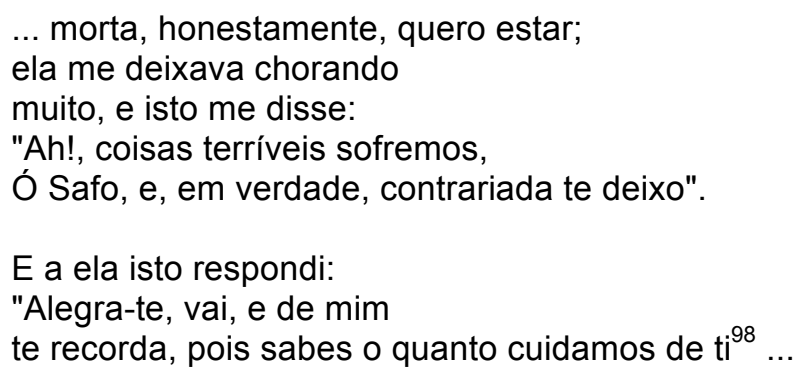

No trecho acima, do "fragmento 94", a deixa. Perceber o verbo conjugado em $3 a$ do plural: "cuidamos de ti". Percebe-se o tom de despedida. Esse é um dos raros exemplos em que se vê a partida e a despedida, que ouvimos da boca da própria hetaira que deixa o grupo.

\author{
... qual deusa manifesta, \\ e (ela) muito se deleitava com tua canção. \\ Mas agora ela se sobressai entre lídias \\ mulheres como, depois do sol \\ posto, a dedirrósea lua
}

\footnotetext{
${ }^{97}$ Versos 15-16 de "Ode à Anactória", Fragmento 16 de Safo de Lesbos por fonte do Papiro de Oxirrinco 1231 (séc. II d.C.). Extraído de RAGUSA, Giuliana. Lira grega: antologia de poesia arcaica. SP: Hedra, 2013.

98 "Fragmento 94" do Papiro de Berlim 9722 (séc. VI d.C.). Conforme: RAGUSA, Giuliana. Lira grega: antologia de poesia arcaica. SP: Hedra, 2013.
} 
E ela muito agitada de lá para cá a recordar a gentil Áttis, com desejo; decerto frágil peito ... se consome...

No fragmento acima, uma hetaira ("companheira") deixou o grupo de Safo. Safo descreve sua agitação e lembranças de Átis, que provavelmente permaneceu com o grupo. "De pensamentos para cá voltada", uma das traduções do fragmento, a ausente foi de Lesbos (a terra de Safo. Os poetas mélicos de Lesbos são célebres por não serem viajantes, permanecem em sua terra) para Lídia, terra estrangeira.

\author{
... Eros de novo - o quebra-membros - me agita, \\ doce-amarga inelutável criatura ... \\ ... ó Áttis, mas a ti tornou-se odioso meu pensamento, e para \\ Andrômeda alças $v^{99}{ }^{99} \ldots$
}

No "fragmento 130" acima, vemos Áttis, já mencionada, deixando Safo para Andrômeda. Especula-se que Andrômeda tivesse outro grupo de hetairas. Vê-se que o "quebra-membros" age não somente no cortejo ou sedução, mas também, e principalmente, na perda, na ausência. E, extremamente importante, no fracasso da "unidade" do "grupo de Safo" (figura de comunidade), pois que é quando seu grupo perde mais e mais meninas que Eros ataca e "solta" os membros. Em Safo vê-se uma ligação, enfim, entre corpo e comunidade.

A comunidade em Safo é corpo constantemente fragmentando-se, perdendo, "soltando" seus membros, ou partidos em ida a outras terras, outros grupos, ou somente ausentes. Quem/o que faz isso é Eros, não símbolo do "erotismo", pois aqui ele não é edificante, não é entendimento-do-homem (humanidade e masculino), mas é responsável pelo afeto que se dá no corpo pela incompletude, perda, ausência. A feminilidade é possível que aqui não seja excesso?

\footnotetext{
99 "Fragmento 130". Constante em RAGUSA, Giuliana. Lira grega: antologia de poesia arcaica.
} SP: Hedra, 2013. 


\section{A morte e o que se deixa}

Morta jazerás, nem memória alguma futura de ti haverá, nem desejo, pois não partilhas das rosas de Piéria; mas invisível na casa de Hades vaguearás, esvoaçada entre vagos corpos ${ }^{100}$...

O fragmento em epígrafe dirige-se, como sempre, a um tu feminino. Segundo Ragusa, a canção é um ataque "a um tu feminino que parece pretender ser (boa) poeta sem o ser: eis o sentido da declaração [...] "pois não partilhas das rosas de Piéria", [...] local de nascimento das Musas ${ }^{101 " . ~ A i ́ ~ v e m o s ~}$ que a morte é esquecimento completo. Vemos também que "desejo" faltará à má poeta, "pois não partilha [ela] das rosas de Piéria". Aí cantar a poesia e ser desejada estão em relação de equivalência. Ninguém a desejará ou lembrará porque ou ela não é poeta ou é má nisso.

Vê-se com isso que "desejo" aí não é sinônimo de erotismo, mas de sobreviver a si mesmo. De ser lembrada pela "obra" de incompletude e fragmento. Com isso a poesia é que se torna a continuação "reprodutiva", a perpetuação, não o erotismo como em Bataille. Para ele, o erotismo é um "apesar" da reprodução; contudo, essa independência da reprodução só acontece entre as partes que podem perpetrá-la (masculino ativo e feminino passivo) e as figuras de "espermatozoide" e "óvulo" constantemente ressurgem.

Vê-se também que não há espíritos no Hades. O que há é uma permanência entre corpos vagos, ou seja, cadáveres. A poesia resistiria à punição do esquecimento e o "desejo" seria a promessa que aqueles que se lembrassem da poeta reservariam a ela. $O$ desejo não sobrelevaria espíritos de corpos para que assim fossem arrebatados por um "erotismo" e "êxtase" enlevadores ou propositores de "questões" ao homem.

$\mathrm{O}$ desejo é somente reservado àqueles que cantam a poesia $\mathrm{e}$ "partilham das rosas da Piéria", uma partilha comunitária e lírica que, em vez de aproximar-se de sua inatual partilha entre seus membros e da questão que

\footnotetext{
100 "Fragmento 55" constante em RAGUSA, Giuliana. Lira grega: antologia de poesia arcaica. SP: Hedra, 2013.

${ }^{101}$ Ragusa, 2013, p. 118.
} 
mais coloca o indivíduo em questão, anula os efeitos de vagueza e o oblívio da morte. Salva-os da possibilidade de transitar entre corpos vagos, lívidos.

Aí se vê perfeitamente a perpetuação ou promessa de uma "atualidade comunitária" que somente se dá em inatualidade, perda, ausência. A comunidade ou "grupo de Safo" continua e permanece, pela escritura, em eterna (in)atualidade.

Depois da morte, a comunidade permanece. No entanto, não há nenhuma colocação de questões ao indivíduo que se segue disso. Este verso de Safo lembra bastante os versos de Paul Celan "die Welt ist fort, ich muss dich tragen":

... e para ti eu deixarei, depois de mim $^{102}$

A diferença é que não ouvimos daquele que fica, o Mesmo que é colocado em questão com a morte de outrem. Ouvimos daquele que vai (em antecedência). Aqui, temos um belíssimo exemplo de que equivaler lírica por uma fala soberana de um "ego", indivíduo ou sujeito foi sempre um erro. Parecemos ouvir esse verso do próprio outro, capaz até de tirar sua subjetividade de cena em dois tempos: "para ti", "depois de mim". O gesto aqui é essencialmente escritural: do outro a outrem.

O que tentamos até aqui foi somente começar a trilhar esse caminho de rever Safo em suas possibilidades escriturais de pensamento.

102 "Fragmento 17" da Ed. Belles Lettres de Reinach-Puech, confome DE LESBOS, Safo. Poemas e fragmentos. Trad.: Joaquim Brasil Fontes. SP: Iluminuras, 2003, p. 57. 
CONCLUSÃO 


\section{O erotismo de Safo não é um erotismo}

Nem portanto há êxtase em Safo. O êxtase é um momento dissociativo em que o indivíduo se abre ao fora, para Bataille. Ele contraprova a experiência e o sujeito. No entanto, o erotismo batailliano é rigorosamente a autoafirmação de um humanismo premente e latente. Ele permite que apenas o homem se extasie. A "parte passiva" da jouissance reafirma uma soberania humanista e masculina mesmo no erotismo, que é para Bataille a "confusão", "apagamento" dos limites entre os seres. O apagamento e a perda de limites é, contudo, apenas sofrido pela "parte passiva". Isso leva a questionar se o homem não se funde a ele mesmo no "erotismo".

A descrição do "êxtase" (por falta de melhor palavra) em Safo parece originar-se de um epíteto de Eros; lysimelés ("o solta membros") designa a ação entorpecente do deus flecheiro enquanto qualidade do Deus ${ }^{103}$. Na mitologia sáfica, o inescapável Eros tem ações reais e fisiológicas sobre a terra negra e os corpos humanos. Sua tradução em Amor só se dá mais tardiamente e suas nuances semânticas aproximam-se mais de ágape e amor fraternal correspondido. A ação de Eros não é a de equivalência entre os homens ou harmonia. Eros, é certo, assume papel ordenador e harmonizador na Teogenia hesiódica, anterior a Safo, mas apenas sobre os deuses e por causa da reprodução sexual - o alcance e os limites dos poderes de Eros e Afrodite é um problema, principalmente na questão da reprodução. Segundo Claude Calame, Afrodite e Eros não regem o coito, a prática sexual em-si, mas tudo o que a precede: a sedução, o arrebatamento, o erotismo. Esse papel ordenador e harmônico de Afrodite, que controla Eros, não existe em Safo ${ }^{104}$. Mesmo suas hetairas, companheiras ou aprendizes, não a correspondem de todo e a todo tempo. De fato, a não correspondência entre amantes parece é a lei e não a exceção.

\footnotetext{
${ }^{103}$ Há uma série de títulos e epítetos a Afrodite que designam seus cultos e aspectos. Importantes para a mitologia sáfica são os seguintes: Pandêmos ("Comum a todos"), Makhanitis ("Urdidora"), Melainis ("Negra", "Noturna"), Symmakhia ("Aliada"), Philommeidês ("Amante dos sorrisos"), Eustephanos ("Bem-coroada"), Khrysee ("Dourada").

${ }^{104}$ É claro que um tal papel ordenador que negamos em Safo, o negamos apenas em um aspecto estético ou imagético. Não nos referimos aqui ao culto de Afrodite ou ao papel sóciosexual, cultural e político de seus efeitos na sociedade grega arcaica; nem ao aspecto cultual da prática mélica/lírica. A estrutura do rito, é inegável, tem um papel ordenador e organizador.
} 


\section{Safo, entre corpo e fragmento}

Às voltas ainda com o corpo, admita-se por alguns instantes que um texto entre o século VI-V como o de Safo espelhe algumas qualidades desse tempo de onde fala de longe e denote algumas características subjetivas da comunidade a que pertence o "pedaço de consciência" que o teve em mão sob gesto de escritura ${ }^{105}$. Ainda nesse gesto suspensivo, deixe-se adicionar que 0 estabelecimento histórico da Grécia arcaica não permite ainda um sujeito; o pedaço de consciência que desapregoa a interdição do silêncio comunitário para levantar sobre a horda uma mão atônita segurando a verdade é o próprio crime de franquear os limites do homem. Que Platão dissesse ouvir de um daimon suas inspirações para inquirir os jovens atenienses foi penalizado com a cicuta. Implicar-se em apregoar deuses pessoais era digno de morte. Assim como Safo seria de todo desentendida e considerada absurda se tomasse o teatro para expressar suas opiniões ou sentimentos ${ }^{106}$.

No entanto, se parece ser, hoje, impossível ver na Grécia arcaica quaisquer circunstâncias históricas para a existência de um "sujeito", já houve quem dissesse ter sido lá o lugar do nascimento da subjetividade justamente com o fenômeno da prática lírica/mélica. Bruno Snell foi um dos primeiros a ter introduzido Safo à Europa. Em seu livro $A$ descoberta do espírito ele afirma o nascimento de uma primeira forma primitiva de subjetividade na lírica arcaica da Grécia antiga. Ele também tem um estudo sobre a lírica de Lesbos, o aclamado Poetarum Lesbiorum Fragmenta, em que verte sua atenção sobre Safo e Alceu, conterrâneos de Mitilene e contemporâneos de data de atividade.

Contudo pareça hoje positivamente absurda, a tese de Snell não está de todo incorreta. Ela se pauta, interpretativamente, em um conceito de história que é de fundamento hegeliano. A motivação do helenista foi resolver o susto prolongado que se tomou com a descoberta de recentes manuscritos desenterrados, de todo diferentes da épica homérica. Influenciado pela teoria dos gêneros clássicos de Goethe e Schadewaldt, que dizia épica, lírica e

\footnotetext{
${ }^{105}$ Essa é a suspensão hipotética e pressuposição básica dos Estudos helênicos de modo geral.

${ }^{106}$ Paul Allen Miller em Lyric texts and lyric consciousness apresenta o interessante conceito de horizonte de expectativa, da parte da plateia; este é um horizonte de significação para a enunciação e, portanto, uma regra comunicativa.
} 
tragédia serem historicamente consecutivas, o raciocínio de Snell é claro e compreensível.

Snell acreditava que a épica homérica espelhou seu tempo de escuridão mítica cuja necessidade de sobrevivência requeria viver em grupos e acatar as opiniões estabelecidas; por isso o narrador onisciente e uma figura mediadora dos eventos narrativos de alcance, fôlego e heroísmo. Para ele, pensar os Hinos homéricos e as extensas epopeias junto aos fragmentos líricos era como pensar dois opostos. Ao mesmo tempo, sem as primeiras, jamais a lírica poderia existir senão seguindo um caminho já adiantado por suas antecessoras estéticas. Isso o leva a afirmar que a lírica arcaica, que ousava dizer "Eu" sem a mediação de um narrador-deus, era o tal nascimento da subjetividade, que só poderia ter lugar depois de tempos de comunidade como os da épica.

Essa concepção histórica não está de modo algum extirpada do vocabulário daqueles que preferem uma aproximação desse tom a obras estéticas. Ela é resultado de uma teoria da história que tem como fundamento a ordem lógica da necessidade e suficiência. Se hoje a tese de Snell se figura como insustentável, é somente porque seus revisores discordam de que os tempos arcaicos apresentassem condições e circunstâncias suficientes para a existência de um sujeito.

Nesse sentido, o que se faz é, em verdade, alargar o tempo mítico de escuridão e vivência comunitária (dóxa) que Snell vê espelhar-se na épica para toda a Grécia arcaica, e reservar o nascimento da subjetividade para o nascimento da propriedade privada e o direito romano. Paul Allen Miller, em Lyric texts and lyric consciousness, quando confere a Catulo o verdadeiro "nascimento" da subjetividade que, segundo ele, requer uma lírica de coletânea, em verdade aproveita-se das circunstâncias históricas que assentariam a dispersão dos eventos em um sujeito de direito.

Nesse sentido, a interpretação dos fragmentos sáficos está restrita a uma esfera de enunciação do corpo inteiriço e não fragmentado porque esse "corpo" não é referenciado a uma subjetividade ou indivíduo a que se reserva tal capacidade de desmonte. Podemos, logo, questionar seu próprio estatuto de corpo, pois que subjetividade sustém seus membros e anima as juntas? São possíveis corpos arcaicos? 
O aspecto desconexo das imagens poéticas do fragmento 31 demonstra algo que resiste para além da imagem. Interpretaria Snell esse aspecto desmontado da "representação" do corpo como uma reunião premente de suas partes? Se Eliane Robert Moraes faz algo semelhante é porque ela interpreta as figuras bestiais e desmontadas de "corpos humanos" como uma fragmentação do indivíduo, "negação do homem" e esgarçamento da subjetividade europeia.

Quando então o corpo esteve completo e qual é a justa medida? Adicionamos a essa linha de dois opostos, talvez, que a fragmentariedade da imaginação, entendida enquanto "processo" de síntese poética da imagem figurativa ou discursiva (tanto em seus aspectos cognitivos e psicológicos), se faz reportar a um problema de linguagem, talvez mesmo um defeito. Se o tema para uma História do corpo deve antes de ser tal entreter-se enquanto signo, símbolo ou índice e, portanto, logos, objeto, que resta, então, de corpo se ele não passa de "pedaços de voz colado às coisas" e é continuamente reduzido e é ignorada sua extensão, peso e medida? A coisa mesma sempre se esquivando do processo de significação para tornar-se outro significante de sentido.

\section{O êxtase em Safo não pode ser um êxtase}

Juntaríamos a isso que apesar de a interpretação mais aceite do fragmento 31 ser um corpo em êxtase como isso dialoga com a ausência de subjetividade? É preciso ressaltar que em Bataille o êxtase é uma fissura do sujeito que o abre ao fora e, por isso, resiste a comunicabilidade, que é o pressuposto da experiência. Logo, o êxtase nega o próprio fundamento de uma subjetividade, a comunicabilidade de suas experiências interiores com o fora, isto é, outra interioridade, outros sujeitos.

Negar a comunicabilidade da experiência é, portanto, negar a experienciação possível de um êxtase qualquer e questionar o estatuto de toda subjetividade. Isso, contudo, não vai tão longe a ponto de negá-la, pois o esgarçamento, a fissura e o abismo não fazem senão deslocar a subjetividade a um outro lugar, já que, se não há controle em sua abertura ao fora, isso não a 
nega, senão apenas a coloca no controle estético de seu fracasso e decapitação. Certo que esse gesto empreende uma negação, mas também inclui uma alteração do mesmo em um estado outro que repete o estatuto de mesmidade anterior em um "mesmo melhorado". A Aufheben é o fundo sistêmico da metafísica que a faz permanecer inquebrantável.

O gesto hermenêutico que insere o fragmento 31 dentro da ordem de uma representação do êxtase levanta duas questões:

O êxtase desloca os princípios da subjetividade ao negar a comunicabilidade da experiência que é seu pressuposto e, logo, sobreleva-a a um estatuto de fracasso que não deixa de ser soberania e autocontrole; logo, uma subjetividade pressuposta é necessária para a atualização do êxtase, dado que este é a própria sublação da subjetividade. Se as circunstâncias históricas não são suficientes para uma subjetividade no período arcaico da Grécia Antiga, como há possibilidade de êxtase e, adicione-se, comunicável?

Se não há subjetividade iminente no período arcaico, é possível que haja corpos? Conquanto haja êxtase e erotismo, é preciso rever a circunstanciação histórica suficiente para um sujeito.

\section{Retomada - êxtase, erotismo e corpo histórico}

Em Bataille o erotismo é um aspecto misterioso do espírito do homem. E que já se soubesse, apesar do mistério inculcado por índices e cifras, que aquilo que os arrebatava e fazia recuar um pouco pertencia de todo modo ao espírito humano, é o que nos faz pensar se uma volta, ou mesmo ida, ao corpo não tenha sido, e ainda seja, uma segunda fase ainda despercebida de um humanismo à primeira vista sem culpas metafísicas. É certo que mesmo Bataille negaria essa alcunha humanista, como deveria lhe ser atrelado 0 epíteto se déssemos por certo de que pensara o homem antes do corpo. Mas a de "iniciado" talvez o agradasse.

O erotismo, contudo fosse aquela parte do homem que parecia resvalar para o desconhecido $e$ as sombras, ainda resiste um pouco ao deslumbramento que somente silencia e, no fim das contas, parece mais moldar e estruturar o ser do homem naquilo que o define do que, como 
pareceu à primeira impressão, negar-Ihe antinomias por contraprova de "instinto", irracionalidade ou qualquer coisa que valesse a fuga de uma conscientização extremada. "L'esprit humain est exposé au plus surprenantes injonctions. Sans cesse, il a peur de lui-même. Ses mouvements érotiques le terrifient" (OC, 1987, p. 11). Predicados ao "espírito humano", seus movimentos eróticos o aterrorizam como as injunções que lhe pertencem às dobradiças de sua forma. O espírito, exposto às próprias injunções, seus movimentos eróticos, surpreende-se com terror e medo.

Mas se o espírito humano é da mesma forma predicado de partes e injunções não é senão porque um claro paralelismo do espírito com o corpo se estabelece desde os princípios. E que o acento recaia nesse aparentemente insolúvel paradoxo, a oposição antes desafia do que atemoriza Bataille. Do mesmo modo que a santa e a volúpia não the parecem, do ponto em que as olha, irresolvíveis, mas convergindo ao mesmo.

Dessa forma, se de fato o erotismo pareceu de relance atemorizar e surpreender o homem, é apenas por que ali em seu espírito, seus "movimentos eróticos" guardavam um certo aspecto prenhe de perguntas e, se estas não foram feitas para serem observadas à luz incidente antes de tomadas ao desafio de decifração, é justamente por serem indagadas no breu que inspiram que o homem torna-se mais corajoso por aproximar-se delas.

Eu não penso que o homem tenha uma oportunidade de fazer um pouco de luz antes de dominar o que o amedronta, não que ele deva esperar um mundo onde não haja mais razão de medo, onde o erotismo e a morte se econtrariam sobre o plano de encadeamentos de uma mecânica. Mas o homem pode dominar o que o amedronta, ele pode encará-lo de frente ${ }^{107}$.

Se é possível encarar de frente aquilo que o amedronta, o homem, mesmo virado à escuridão plena de que seu espírito é feito, pode dominar o erotismo e a morte.

O erotismo, os "movimentos eróticos" do espírito humano e a morte que Bataille equivale àquele e que, sobretudo, aterrorizam-no, podem ser dominados e superados, mesmo ultrapassados. Contudo, se é às próprias injunções que o espírito humano se expõe, se são os movimentos eróticos ali

${ }^{107}$ Id. Ibid. p. 11 
nas dobradiças de seu espírito que o aterrorizam, o homem, ao dominar e superar aquilo que o aterroriza, supera e domina seu próprio espírito, isto é, a si próprio.

Nesse sentido, não é diferente o erotismo e a morte daquela besta excluída e assinalada acima da mediocridade humana e que é discriminada pela sua diferença aos homens. Ambos erotismo e morte funcionam como aquele traço assistêmico e fora da regra que, no entanto, acaba por ser o princípio e possibilidade de funcionamento de todo o sistema humanista. É por isso que o homem que domina e supera seu próprio espírito, pois é dali que vem os movimentos eróticos que o aterrorizam, sai impune a seu desconhecimento de si mesmo. "Ele escapa por esse preço do estranho desconhecimento de si mesmo que até aqui o definiu" (Id. Ibid. p. 11).

Da mesma forma o corpo, enquanto lugar de pensamento, que, em vez de servir como esperança de questões novas e refrescar com um tanto de sopro as já acostumadas perguntas de um humanismo cansado de interrogar os espíritos, acaba por reassimilá-lo em paráfrases rejuvenescidas das mesmas perguntas e mesmas expectativas de respostas.

É dessa forma que o erotismo, e a extensão do espírito que este acaba por figurar, não é senão mais uma forma de entendimento do homem e seu espírito. De uma certa forma, não é surpreendente que o humanismo se revele como humanismo viril. E propor o corpo como "lugar de deslumbramento" não deixa de ser gesto político de ordenação e valoração, consequentemente, de corpos masculinos e femininos, pois o erotismo é questão de jouissance independente da reprodução sexual, o que não descarta uma relação entre erotismo e reprodução sexual e, portanto, entre forma de entendimento de ser e sistemas de pensamento baseados em biologismo, naturalismo e heteronormatividade.

O erotismo, se visto como entendimento do espírito, entenda-se homem, deve propor uma fisiologia e morfologia erótica; e, sobretudo, valorar os posicionamentos, as atitudes e táticas de uma práxis eromata que, a esse ponto, não deixa de se diferenciar de uma normatização, diga-se prescritiva, de papeis sociais e sexuais a um só tempo. Tendo em vista, aliás, e não somente, que um erotismo que se pretenda forma de entendimento do homem deve também comprometer-se ontologicamente, não há saída para um erotismo 
enquanto "dispêndio improdutivo" em que dispêndio e improdutividade não sejam senão reafirmações de uma soberania sobrelevada.

A proposição de um ser a cujo entendimento se chegue com a prática erótica ou com seu pensá-la deveria ponderar sobre as várias formas de prática sexual e seus praticantes, pois dizer que o gozo independe da lógica reprodutiva é já pressupô-la enquanto princípio do erotismo, sabendo-se que aquilo de que se releva o erotismo também desprende do fundo aspectos fundamentais, levando-os consigo assimilados; portanto, o pôr de lado da lógica reprodutiva a põe em reserva e apesar de prescindi-la, o erotismo deve tê-la como pressuposto. É nessa lógica que, por exemplo, tem-se a possibilidade de analogia (e justificativa) ao espermatozoide e o óvulo.

\section{Fragmenta}

A noção aqui apresentada de "fragmento" é diferente do conceito moderno de fragmento, pode-se dizer que com suas heranças em Nietzsche e Walter Benjamin. Nietzsche é mestre da forma filosófica do axioma ou da máxima cuja citacionalidade sobrevive à argumentação pormenorizada ou o detalhamento das frases, ainda polêmicas. Walter Benjamin apresenta um entendimento formal de fragmento que é uma noção individuada de uma totalidade curta, breve, formalmente concisa.

A noção aqui de fragmento é a de uma totalidade perdida. Incompletude, inacabamento. De fato, uma incompletude, um inacabamento, o fragmento, portanto, nesse sentido, não pode pertencer à literatura senão às margens. Ele indica um processo interminado de consciência de intencionalidade. Indica portanto, ausência de uma soberania reguladora que verificaria e atestaria pela finitude de representação e querer-dizer.

Talvez por isso Safo esteja de todo ausente das discussões canônicas e seu interesse apenas consista em estudos de língua, antropologia e seus fragmentos sejam analisados enquanto documentos de uma sociedade perdida. É preciso restituir o fragmento a uma textualidade, não acabada, terminada, completa. É preciso entender sua incompletude enquanto 
impossibilidade de acontecimento escritural, e portanto, acontecimento escritural de fato.

O inacabado, incompleto e, por isso, o fragmento sáfico apontam para um entendimento de acontecimento que teoreticamente foi apenas discutido em Jacques Derrida. Sua concepção de acontecimento não compreende o acontecido, o acabado, o alcançado. Compreende o acontecimento em sua inatualidade mais pura, sua impossibilidade de vinda, de realização. Ele é inscrito em um messianismo da promessa em que não há promessa de vinda sem também ameaça de inatualidade.

A figura do envio em Derrida é "estruturalmente" semelhante. O endereçamento compreende a perda, o desvio, o extravio enquanto parte de sua atualização. A ameaça não é o parasitismo, a exceção de um fracasso da completude desejada e bem-sucedida que é a regra. A ameaça de extravio, perda, incompletude, não-vinda é idêntica à promessa de sucesso. Por isso o acontecimento, além de permanecer em inatualidade, tem sua possibilidade de fracasso como parte de suas condições de possibilidade. A síntese desse argumento é a impossibilidade: ela abarca o fracasso, a não-vinda, a incompletude como estruturantes da condição de possibilidade do sucesso, completude, totalidade.

O que os fragmentos sáficos nos demonstram é um atraso da concepção moderna de literatura em relação ao corpus disponível. Esta é a síntese de nossa proposta: a noção de fragmento como exemplificada por Safo e os poetas arcaicos é a resposta antes da pergunta para "o que é escritura?". Os fragmentos arcaicos, incompletos, desintegrados, aquém de qualquer individuação, são a condição de possibilidade para um "sucesso" literário entendido enquanto totalidade, seja breve ou de fôlego. 


\section{Referências bibliográficas}

AGAMBEN, Giorgio. A comunidade que vem. SP: Autêntica, 2013.

ARISTÓTELES. Poética. Trad. Eudoro de Sousa. Lisboa: Imprensa Nacional/

Casa da Moeda, 1992.

BATAILLE, Georges. O erotismo. Trad. Antonio Carlos Viana. s/l: L\&PM Editores, s.d.

. CEuvres complètes. Paris: Gallimard, 1987.

BUDELLMAN, Felix. Cambridge Companion to Greek Lyric. Londres: Oxford University Press, 2010.

BLANCHOT. La communauté inavouable. Paris: Les Éditions de Minuit, 1983. . L'écriture du desastre. Paris: Gallimard, 1980.

. L'espace litteraire. Paris: Gallimard, 1955.

. O livro porvir. SP: Martins Fontes, 2005.

BLOOM, Harold. A angústia da influência: uma teoria da poesia. Trad. Arthur Nestrovski. Rio de Janeiro: Imago Ed., 1991.

BRASIL FONTES, Joaquim. Eros, tecelão de mitos. São Paulo: lluminuras, 2003.

CALAME, Claude. Eros na Grécia antiga. Trad. Isa Etel Kopelman. São Paulo: Perspectiva, 2013.

. La poésie lyrique grecque, un genre inexistant?. In: Littérature, N¹11, 1998. pp. $87-110$.

. Craft of poetic speech in ancient Greece. Trad. Janice Orion. London:

Cornell, 1995.

CULLER, Jonathan. Theory of the lyric. s.I: s/n, s/d

COLLOT, Michel. O sujeito lírico fora de si. Revista Terceira Margem. Trad. AlbertoPucheu. Rio de Janeiro: 7 Letras, ano VIII, n. 11, 2004, p. 165-177.

CORBIN, Alain; COURTINE, Jean-Jacques; VIGARELLO, Georges (Orgs.). História do corpo I, II e III. Trad. João Batista Kreuch, Jaime Clasen. Petrópolis, RJ: Vozes, 2009, 3 volumes.

DELEUZE, Gilles. Crítica e clínica. SP: Ed. 34, 1997. . Mil platôs, vol. I. SP: Ed. 34, 1995. 
Mil platôs, vol. II. SP: Ed. 34, 1995.

DERRIDA, Jacques. Heidegger: la question de l'Etre e l'Histoire. Paris: Éditions Galillé, 2013.

DERRIDA, Jacques. Heidegger et la question. Paris: Flammarion, 2010.

DERRIDA, Jacques. On touching - Jean-Luc Nancy. Trad. (ing.) Christiane Irrizary.

California: Stanford University Press, 2005.

DERRIDA, Jacques. Gramatologia. Trad. Miriam Schneidermann e Roberto Janini Ribeiro. São Paulo: Perspectiva; Edusp, 1973.

DERRIDA, Jacques. A voz e o fenômeno. Trad. Lucy Magalhães. Rio de Janeiro, Jorge Zahar Ed., 1994.

. Pensar em não ver. MICHAUD, Ginette; MASÒ, Joana; BASSAS, Javier (Org.)Trad. Marcelo Jacques de Moraes. Florianópolis: UFSC, 2012.

. Introduction et traduction de "L'Origine de la géométrie", de Husserl. Paris: PUF, 1962.

. De la grammatologie. Paris: Minuit, 1967.

. L'écriture et la différence. Paris: Seuil, 1967.

. La voix et le phénomène, Introduction au problème du signe dans la phénoménologie de Husserl. Paris: PUF, 1967.

. Marges de la philosophie. Paris: Minuit, 1972

. Circonfession In: "Jacques Derrida", av. Geoffrey Bennington. Paris:

Seuil, 1991.

. Points de suspension. Entretiens. Paris: Galilée, 1991.

. Nous autres grecs In: "Nos Grecs et leurs modernes - Les Stratégies contemporaines d'appropriation de l'Antiquité". Paris: Seuil, 1992.

. Khôra. Paris: Galilée, 1993.

. Passions. Paris: Galilée, 1993

. Sauf le nom. Paris: Galilée, 1993

. Spectres de Marx. Paris: Galilée, 1993

DICKINSON, Emily. A branca voz da solidão. Trad. José Lira. - Ed. bilíngue São Paulo: lluminuras, 2011.

EYBEN, Piero. Escritura do retorno: Mallarmé, Joyce e meta-signo. Vinhedo: Horizonte, 2012. 
EYBEN, Piero; PUCHEU, Alberto (org.). Danielle Cohen-Levinas. Partilha da literatura. Vinhedo: Horizonte, 2014.

FOUCAULT, Michel. Hermenêutica do sujeito. Trad. Márcio Alves da Fonseca, Salma Tannus Michail. SP: Martins Fontes, 2006.

FRIEDRICH, Hugo. A estrutura da lírica moderna. Trad. Marise M. Curioni. São Paulo: Duas Cidades, 1978.

GROSSMAN, Évelyne. Entre corps et langue: l'espace du texte (Antonin Artaud, James Joyce). Tese de doutoramento d'Etat ès Lettres et Sciences humaines defendida em l'Université Paris 7, 20 de dezembro de 1994.

HAMBURGER, Michael. A verdade da poesia. São Paulo: Cosac Naify, 2007.

HEGEL, G.W.F. Cursos de estética I. Trad. Marco Aurélio Werle. - $2^{\mathrm{a}}$ ed. rev. São Paulo: Editora da Universidade de São Paulo, 2011.

HEGEL, G.W.F. Fenomenologia do espírito. Trad. Paulo Meneses. Petrópolis: Vozes, 1992.

HEIDEGGER, MARTIN. Ser e tempo. Trad. Fausto Castilho. São Paulo: Editora Unicamp; Vozes, 2012.

KOJÈVE, Alexandre. Introdução à leitura de Hegel. Trad. Estela dos Santos Abreu. RJ: Contraponto: EDUERJ, 2002.

KRISTEVA, Julia. La révolution du langage poétique. Paris: Seuil, 1974.

LEVINAS, Emmanuel. Totalité et infini: essai sur l'extérioté. Paris: Kluwer Academic, 1971.

. Entre nous: essai sur le penser-à-l'autre. Paris: Grasset, 1991.

LIMA, Luiz Costa. Lira e antilira: Mário, Drummond, Cabral. - 2a ed. rev. - Rio de Janeiro: Topbooks, 1995.

LOTMAN, luri. A estrutura do texto artístico. Trad. Maria do Carmo Vieira Raposo e Alberto Raposo. Lisboa: Editorial Estampa, 1978.

Leonardo da Vinci. Anatomical drawings from the Royal Library, Windsor Castle. John P. O'Neil (Ed.). Nova Iorque: The Metropolitan Museum of Art, 1983.

LYRA, Lucas. Prelúdio a políticas poéticas. Brasília: Repositório BCE, 2014.

MALABOU, Catherine. La plasticité au soir de l'écriture. Paris: Éditions Leo Scheer, 2005.

MICHON, Pascal. Marcel Mauss retrouvé: origines de l'anthropologie du rythme. s.l. Éditions Rhuthmos, 2010. 
MILLER, Paul Allen. Lyric texts and lyric consciousness. NY: Routledge, 1994. MORAES, Eliane Robert. O corpo impossível: de Lautréamont a Bataille. São Paulo: lluminuras, 2012.

MORAES, Eliane Robert. A obscena senhora Hilst. Jornal do Brasil, Rio de Janeiro, 12 maio 1990. Ideias/Livros.

NASCIMENTO, Evando. Derrida e a literatura: 'notas' de literatura e filosofia nos textos de desconstrução. $2^{\mathrm{a}}$ ed. Niterói: EdUFF, 2001.

NANCY, Jean-Luc. Corpus. Lisboa: Vega Ltda, 2000.

. La communauté desoeuvrée. Paris: Christian Bourgeois éditeur, 1999. . La communauté desavouée. Paris: Éditions Galillé, 2014.

PAZ, Octavio. O arco e a lira. Trad. Ari Roitman e Paulina Wacht. São Paulo: Cosac Naify, 2012.

PENNA, João Camillo; DIAS, Ângela Maria (Org.). Comunidades sem fim. Rio de Janeiro: Editora Circuito, 2014.

POUND, Ezra. ABC da literatura. Trad. Augusto de Campos e José Paulo Paes. Augusto de Campos (Org.). São Paulo: Cultrix, 2006

RAGUSA, Giuliana. Fragmentos de uma deusa: a representação de Afrodite na lírica de Safo. Campinas, SP: Unicamp, 2005.

RAGUSA, Giuliana (Org.). Lira grega: antologia de poesia arcaica. São Paulo: Hedra, 2013.

SNELL, Bruno. A descoberta do espírito. SP: Editora 70, 1992.

SPITZER, Leo. Três poemas sobre o êxtase. Trad. Samuel Titan Jr. SP: Cosac Naify, 2003.

STAIGER, Emil. Conceitos fundamentais da poética. Rio de Janeiro: GB, 1972. 